
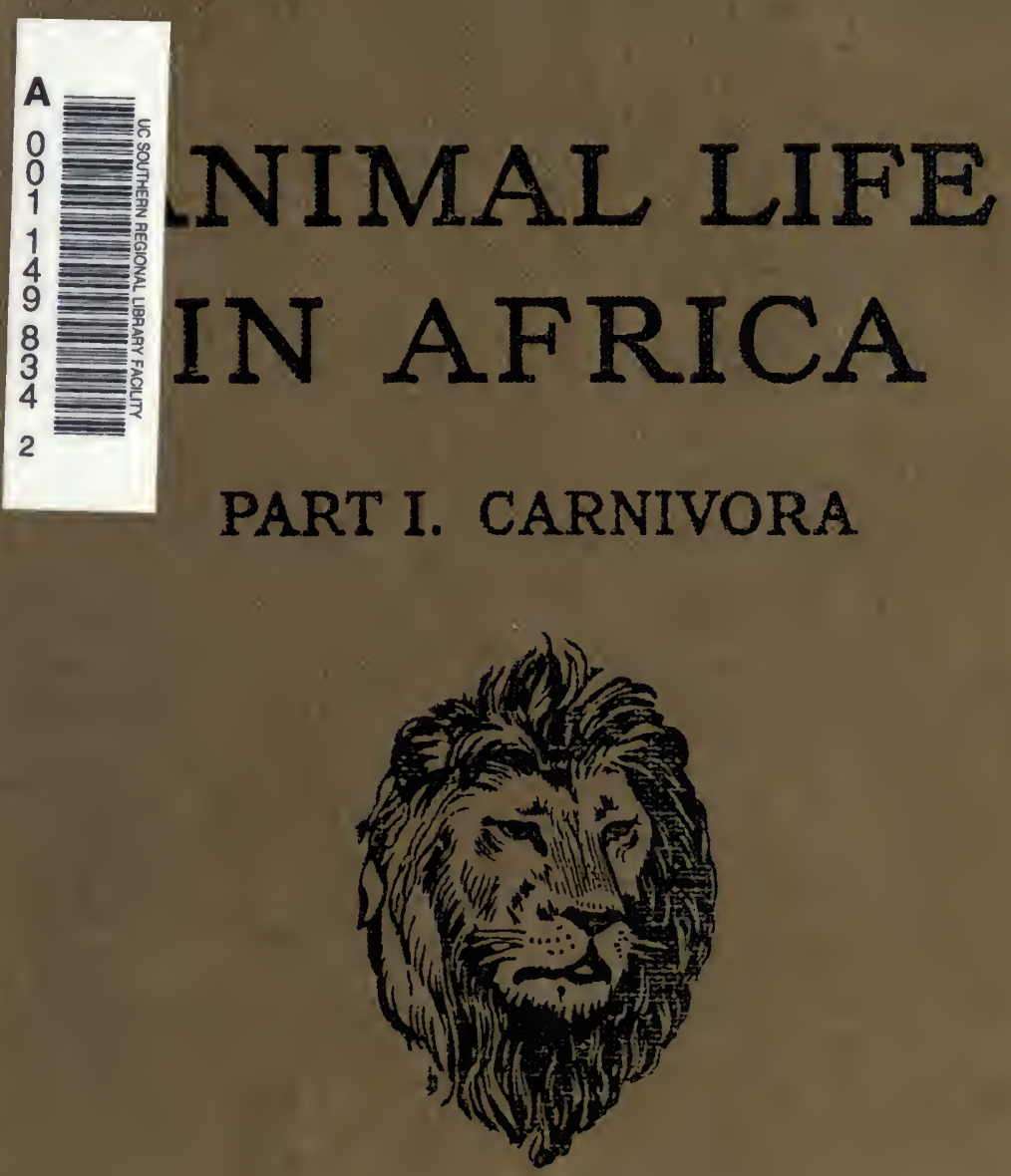

BY

MAJOR J.STEVENSON-HAMILTON 


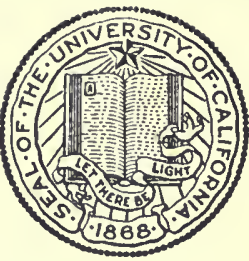

THE LIBRARY

OF

THE UNIVERSITY

OF CALIFORNIA

LOS ANGELES 


$$
\text { . }
$$





\section{ANIMAL LIFE \\ I N A F R I C A}




\section{THE HERO READERS}

SHACKLETON IN THE ANTARCTIC By Sir Ernest Shackleton, C.V.O., 256 pages, 48 full-page Illustrations from photographs. Price Is $6 \mathrm{~d}$.

In this book which has been specially prepared for young people, the author tells in direct and simple language the thrilling story of his adven. turous journey in the Antarctic Regions.

BRITISH SOLDIER HEROES, with a Preface by EARL ROBERTS, V.C., F.M. In two parts, each 256 pages, Illustrated. Price is 6d each.

SERIES I. Cromwell, Marlborough, Peterborough, Wolfe, Clive, Coote.

Series II. Heathfield, Lake, Moore, Abercromby, Baird, Wellington.

BRITISH SAILOR HEROES. In two parts. Each $25^{6}$ pages, Illustrated. Price is $6 \mathrm{~d}$ each.

Series I. Howard, Drake, Blake, Rooke, Anson, Hawke.

Series II. Boscawen, Rodney, Howe, Hood, St. Vincent, Nelson.

It is now generally recognized that historyteaching by means of biographies adds considerably to the interest of the subject, and teachers will find that the above books will make a direct appeal to the young reader.

\section{LONDON}

WILLIAM HEINEMANN 2 I BEDFORD ST., W.C. 
Digitized by the Internet Archive in 2007 with funding from Microsoft Corporation 


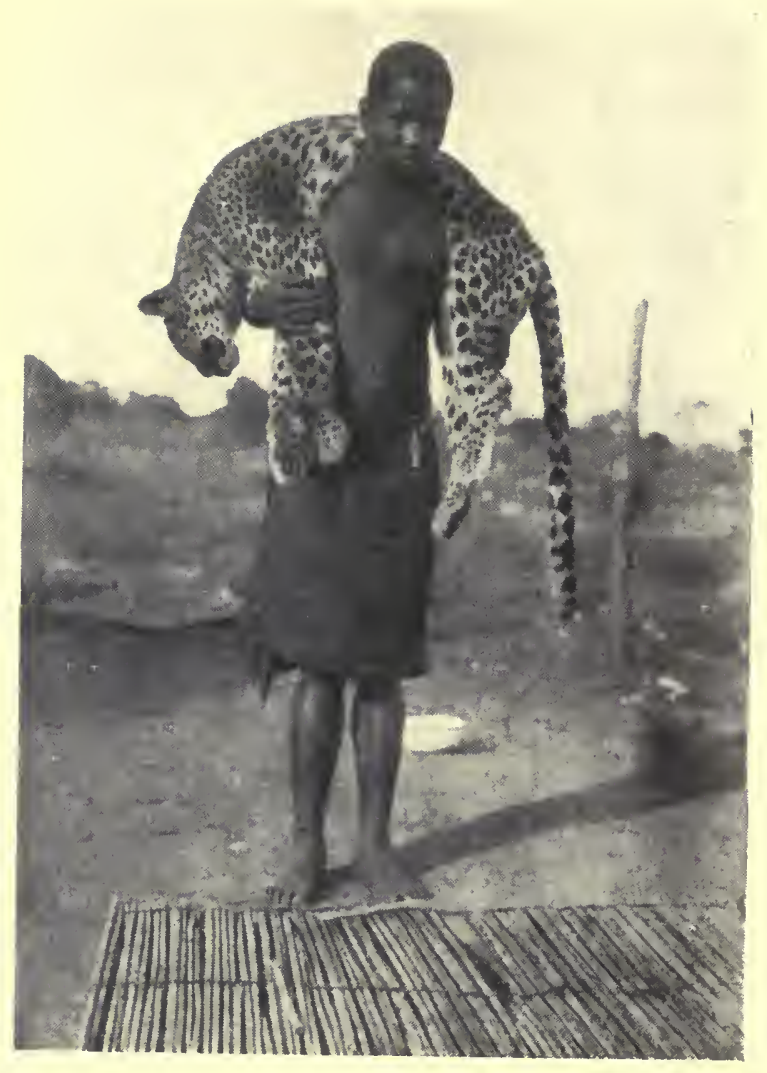

FEMALE LEOPARD

(Sabi Game Reserve) 


\section{ANIMAL L IFE \\ I N A F R I C A}

BY MAJOR T. STEVENSON-HAMILTON F.R.G.S., C.M.Z.S., LATE 6TH (INNISKILLING) DRAGOONS WARDEN OF THE TRANSVAAL GOVERNMENT GAME RESERVES

BOOK I

\section{A R N I V O R A}

WITH CHAPTERS ON APES, MONKEYS, BABOONS AND SOME MISCELLANEOUS TYPES

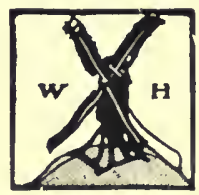

L O N D O N

WILLI A M HEINEM A N N 
London: William Heinemann 1917 
have certain characteristics in common by means of which they are distinguished from all others.

FAMILY : A group of animals consisting of one or more genera. A family is, of course, a wider classification than a genus, and the characteristics which its members have in common are fewer in number. Thus a dog and a fox belong to the same family, though of different genera.

ORDER: An order is a still more comprehensive group, and consists of animals which are alike in only a very few special features. Thus all flesh-eating animals, to whatever family they belong, are placed in the order Carnivora, and all herb-eating animals in the order Herbivora.

Class: This is the largest group of all, and consists of animals which have the broadest and most general characteristics in common.

The principal of the eight classes into which the Vertebrates, or those animals which are possessed of a backbone, are divided are :

(I) Mammals: Warm-blooded animals which suckle their young.

(2) BIRDS, which are warm-blooded animals, covered with feathers, and usually, though not always, possessed of the power of flight.

(3) Reptiles, which are cold-blooded primitive animals, with a skin formed of horny plates or scales, but which breathe in the same manner as the foregoing.

(4) Amphibians : Cold-blooded primitive animals, whose young are aquatic and breathe through gills like fishes. Frogs, toads, newts, and salamanders are amphibians. 
(5) Fishes : Cold-blooded aquatic animals, which breathe air through gills during their whole lives.

The above five large classes, together with three others consisting of small marine creatures, make up the Vertebrate sub-kingdom of the great Animal kingdom.

It might seem superfluous to go further and define what an "animal" really is, were it not that there occurs not infrequent misconception on the point. An animal, then, is that which can be classed neither as a vegetable nor as a mineral, and so the term includes all birds, reptiles, fishes and insects.

Other descriptive terms used are explained in the text. A few of the most common, however, are, for convenience of reference, given below.

ARBOREAL: Used to describe animals which live in, or habitually frequent trees.

NocturNal: Used to describe animals which lie up during the daytime and issue forth to hunt their food, \&c., at night.

Migratory: Used to describe animals which wander regularly or occasionally from one region to another. PACHYDERMS: Thick-skinned animals, such as the elephant, rhinoceros, and hippopotamus.

UNGULATES : Hoofed animals.

Specialization: The development of an organ of the body in some special direction. In whatever degree groups or species of animals have" developed peculiarities of structure distinguishing them each from older and more simply formed groups or species, so are they described as being more or less highly specialized.

Environment: The surroundings of the animal, and the external conditions with which it constantly comes into contact. 
RUDIMENTARY: An organ is said to be rudimentary when it is not fully developed, or is in an early stage of development.

Plantigrade: A term applied to animals which walk on the soles of their feet, and on what in human beings would be the palms of the hands (elephants, bears, \&c.).

DigitigRADE: A term applied to animals which walk upon what would be among human beings the points of the toes and the ends of the fingers. The wrist and heel thus become what are termed in the horse the knee and the point of the hock respectively. Among the carnivora the first joint of the fingers becomes a pad on which the animal walks, and the nails, instead of solidifying into hoofs, as among the majority of the herbivora, become claws for scraping or for holding prey. The large majority of both carnivorous and herbivorous animals are digitigrade.

FAUna: The fauna of a country implies its animal as distinct from its plant life (flora).

Ruminants : Ungulates which chew the cud.

Bovide: That large family of the ruminants which have their horns in the form of a hollow sheath enclosing a bony core and do not cast them annually like the Cervidae or deer family. Cattle, sheep, and antelopes belong to the Bovide family.

Antelope: This term is popularly applied to those of the hollow-horned ruminants which are neither cattle, sheep, nor goats. It is incapable of any clearer definition. Some tribes of antelopes appear more nearly to resemble the cattle and buffaloes, others the goats.

J. Stevenson-Hamilton 


\section{CONTENTS}

\section{PART I \\ THE FLESH-EATERS}

CHAP.

I. CARNIVOROUS OR FLESH-EATING

PAGE MAMMALS

I

II. THE LION

IO

III. THE LION (continued)

IV. THE LION (continued)

V. THE LEOPARD

VI. SMALLER CATS

VII. THE HUNTING LEOPARD, OR CHITA

VIII. VIVERRINES-THE AFRICAN CIVET, GENETS. MUNGOOSES

IX. THE AARDWOLI; HYENAS

X. JACKALS AND FOXES

XI. THE AFRICAN HUNTING DOG 103

XII, OTTERS, THE RATEL, POLECATS 


\section{PART II}

\section{SOME GNAWERS AND INSECT EATERS}

CHAP.

XIII. HARES, SQUIRRELS, THE CANE RAT, THE PORCUPINE, JERBOAS, PANGOLINS, THE ANT-BEAR

XIV. APES AND MONKEYS 


\title{
ANIMAL LIFE IN AFRICA
}

\section{BOOK I : CARNIVORA}

\author{
PART I \\ THE FLESH-EATERS
}

\section{CHAPTER I \\ CARNIVOROUS, OR FLESH-EATING MAMMALS \\ Definition : Habits : Methods of Capturing Prey}

ALL animals which suckle their young belong to the class known as mammals. Thus, man, the cat, the cow and the mouse are all mammals, for although in other respects they differ widely, yet they all have this in common, that they suckle their young.

Classes are again divided into orders. The lion and the antelope are both mammals, but they belong to different orders. Lions, and other animals which are flesh-eating, belong to the order Carnivora; antelopes, and other animals which live on grass and herbs belong to the order Herbivora.

The order Carnivora, then, contains the flesh-eating mammals. These are again divided into two sub-ordersTerrestrial, those that live on land, and Marine, those that live in water.

All flesh-eating mammals have certain common characteristics. Their toes, of which there are never less than 
four, are always provided with claws, which may be retractile-that is, capable of being withdrawn at will within a natural sheath-or otherwise. The shape and arrangement of the teeth, too, are similar. There are generally three pairs of incisors, or front teeth, in the upper and lower jaws, and there are always on each side of the mouth, two carnassial, or canine teethone above and the other below-which form a pair of blades acting on one another like scissors.

Terrestrial carnivora-flesh-eating mammals which live on land-include, of course, many different types of animals. In order, therefore, to prevent confusion in studying them, they are further split up into three great divisions - the cats, the dogs, and the bears. The animals belonging to each of these divisions have certain points in common with regard to the structure of their bodies, and it is by means of these likenesses that we are enabled to classify them.

(A) The first division-the cats-is made up as follows :

(I) The Cat Family, which consists of the true cats, and the Chita.

The former are more specialized, more fully adapted for their peculiar conditions of life, than any other of the carnivora. The head is short and rounded, the teeth are reduced in number and modified in shape to fit them for the work they have to do, while the claws are long, sharp, and fully retractile. They comprise. in Africa, the following species: The lion, the leopard, the serval, the black-footed wild cat, the African wild cat, the African tiger-cat, the jungle cat, and the caracal.

(2) The Viverrine Family. This is a very large family. Its members are animals possessed of long heads 
and bodies, with short legs. The cheek teeth are more numerous than among the cats, and the lower back teeth are provided with grinding surfaces behind the blades. The claws vary in retractability, and some species walk upon the soles of their feet (plantigrade) and not upon their toes (digitigrade) as most ungulates, or hoofed mammals, and other carnivores do. The family consists of the following genera : *

The civet, the genets, the mungooses and the meercats.

(3) This family contains only the aardwolf.

(4) The Hyæna Family.

(B) The second division contains in Africa, the jackals, the African foxes, and the African hunting dog.

(C) The third division contains, in Africa, south of the Sahara, the Cape otter, the spotted-necked otter, the ratel, and the polecats.

The Marine sub-order of mammals is represented in South Africa by the Cape sea lion.

Although all the animals mentioned above are embraced under the heading of flesh-eating animals, several of the forms are not strictly so in reality, insects and fruits forming a large part, in some cases nearly the whole of their diet. All the members of the order display very perfect adaptation to their mode of life and to their environment. While the larger species have varied little in shape and colour from their original types during the ages in which they have roamed over the Ethiopian region, the smaller forms have often altered a good deal.

In south-east Africa the young of most of the carnivora seem to be born during the dry season, which is the reverse of the general rule controlling the reproduction of the majority of the ungulates. Though it is rash to pro-

* This and other terms used in the classification of animals are explained in the Introduction, pages vii-x. 
pound theories in such matters, it is at least worth notice that the time when the young carnivora become of an age to accompany their mothers coincides with the period when the other order are usually producing their offspring.

Purely flesh-eating carnivora cannot, like hoofed mammals, be classed into bush and plain-loving species; the nature of the district in which they live does not appear to matter much so long as it contains their natural prey, and suits their various individual methods of securing it. All the species are nocturnal, or seminocturnal, in their habits, and like to spend the hours of daylight sleeping, concealed in bush, grass, holes, a or often quite in the open, sheltered from the direct rays of the sun by some slight shade. They are seldom found far from water, partly because a considerable quantity of the element is necessary to them, and partly because its vicinity forms their most convenient hunting-ground. At night, when in pursuit of food, they often wander far afield, but cockcrow generally finds them near a drinking place of some kind. They all have great capacity for seeing in the dark, and hearing, scent and eyesight are, in most cases, remarkably developed. Their intelligence, too, is very high; indeed, were it not in advance of that possessed by the swift-footed creatures upon which most depend for their food, it is obvious that they could not long have survived in the struggle for existence.

Although, generally speaking, flesh-eating prey upon herb-eating mammals, or upon birds of different kinds, the various species will attack each other on occasion. Thus I have known leopards to kill and eat genets and civets; lions and leopards will prey upon wild dogs-a compliment which the latter would certainly return 
did a fitting opportunity offer. A civet once killed and ate one of my domestic cats. I have heard of wild dogs hunting both jackals and hyænas, though I do not know whether they would go so far as to eat the latter animal. Hyænas, in their turn will finish off and devour any animal if helpless and weak from age or illness, without regard to whether it is carnivorous or otherwise, so long as it does not belong to their own species; and they look upon small dogs and cats as delicacies. The fondness of leopards for domestic dogs as an article of diet is proverbial. Although it is a good general rule that no animal will eat another of the same species, isolated cases of cannibalism do occasionally occur-more frequently amongst the cat family than elsewhere, I think.

Unlike the herb-eating animals, through whose systems, in order that strength may be duly maintained, a more or less regular quantity of food must pass daily, the wild carnivora are by their nature suited to spend their lives in alternately gorging to repletion, and undergoing relatively long periods of abstinence. This adaptation to conditions has, of course, been the necessary condition of their survival, for, whereas under ordinary circumstances the vegetable-eating creature finds food always to hand, the meat eater has to hunt for his, and to depend on the superiority of his cunning and activity in order to secure it. Thus, when fortune is unkind, he may have to endure considerable periods on an empty stomach, and it is important to his existence that this enforced hunger, within due limits, shall not interfere with his bodily strength. Carnivorous animals, therefore, after having eaten all they can at one meal, like to lie down and sleep off the immediate effects. Should anything remain of their " kill," they remain as close at hand as possible, returning to it in the intervals of their waking moments, and so 
spend their time alternately gorging and sleeping until no more remains. They then continue to take their ease, without a thought of the future, until hunger prompts them once more to wander abroad in search of prey. Exceptions to this procedure sometimes occur among certain species, and in localities where food is so exceedingly plentiful that it can be obtained practically at will, and is not therefore so precious as to call for consumption down to the last morsel.

Carnivora capture their prey by surprise, by ambush, or by over-hauling it in fair chase. The two first are the methods adopted by the retractile clawed members of the order, which, from the nature of their feet and general construction, are less suited to moving long distances at speed than are such of the others as are possessed of stout non-retractile claws, together with bodies and limbs specially fashioned for running fast. Generally speaking, beasts of prey hunt by night, and, when not lying in ambush in places where animals are likely to pass, prowl about within certain fairly well-defined areas until they scent their quarry, when they endeavour to work up wind to it. Outside this general definition, the means employed vary greatly according to the nature of both hunter and hunted, and to the attendant circumstances of each particular case.

A very high standard of intelligence, and, where individuals hunt in parties, a remarkable faculty for combination, is often shown. Animals are sometimes permitted to get the scent or catch sight of one or more of their pursuers that they may rush headlong towards a point where, others are waiting concealed down wind. The habits and nature of each varying form of prey, be it buffalo, zebra, antelope or pig, are provided for, and the best method of pursuing and ultimately killing each is 
selected. Amazing patience is always displayed, and the quarry is often followed by scent for many hours, or even days, until a suitable opportunity presents itself for getting on terms with it. When close quarters are reached sight takes the place of scent, and the eyes of all beasts of prey, especially the cats, show a remarkable adaptability to the amount of light available.

The theory which I have once or twice heard advanced, that the hunting is done only by sight, does not appear to have any solid foundation. I have repeatedly seen predatory animals of various sorts, when hunger forces them to be afoot by day, sniffing the breeze for some sign of game being in the neighbourhood, and lions and wild dogs will on occasion work out a spoor like foxhounds. When $\mathrm{Mr}$. Wolhuter, wounded after his successful struggle with a lion, was awaiting assistance in the comparative safety of a tree, he noticed how the second lion came trotting along with head to earth, nosing out every inch of the ground along which he had been dragged; and it is a matter of common knowledge that one of the best methods of bringing carnivora up to a certain spot, is to haul the intestines of a buck in a semicircle over as large an area as possible.

That hunted animals also are capable of divining the presence of their natural enemies by scent there is little room for doubt; but it is a very remarkable thing that a leopard is able to lie for hours within a few yards of a drinking place, or by the side of a gametrack, without bucks apparently having any suspicion of his presence until he springs out upon one which happens to approach within reach. It may be that the wind is always carefully studied; but I know of drinking places on the Sabi where leopards continually catch impala, and where the spots selected for concealment are so surrounded by the latter when they are approaching and leaving 
the water that it is difficult to understand how they did not detect the presence of a foe. Certain it is that no human being could thus have evaded notice.

There can be no doubt that, under natural conditions, the existence of a certain number of predatory animals is beneficial to the condition of the game within any given area, strange though it may sound to say so. The aged and the less fit are killed off, and the herbivora, which, if allowed to increase unmolested, would quickly eat up all the vegetation of a country, are kept within due limits. Obviously, where man, armed with modern weapons, desires to take his share, the candle cannot thus be burned at both ends without permanent harm resulting, and it then becomes necessary to keep down artificially the predatory beasts by every means possible.

Most flesh-eating animals change their ordinary diet only under pressure of hunger. Normally, they prey upon some species which is at once abundant and can be overcome with the smallest expenditure of energy. It is when such food fails, or becomes scarce, that they are forced to take what they can find.

" It is true that there are perverted individuals among animals, just as there are objectionable characters among men, and these, by their overt acts, tend to discredit their class as a whole. Yet both are comparatively rare. Nature carefully_safeguards the permanency and welfare of a species by making the healthy and virile individuals wary, agile, and elusive, so that their natural enemies are forced in the main to content themselves with the less favoured individuals. The wolf that pulls down the sick or enfeebled deer, or the hawk that devours the crippled quail, is really benefiting the species it preys upon, though at the expense of the individual, since by the removal of the weak and unfit, more vigorous stock is secured and 
the danger of outbreaks of disease materially lessened. It is demonstrable that, so long as a useful species is kept within bounds, and is not allowed to increase beyond its normal food-supply, just so long will it fulfil its natural mission and be of true economic value. If, however, the staple food-supply temporarily fails, then, in the effort to maintain life, the animal is likely to become obnoxious." *

I remember being once witness of an instance illustrating the truth of the last sentence. I had arrived at a native village in Portuguese territory, where the people at once complained to me of the depredations of two lions, which for several months had been practically living entirely upon goats and sheep in the district. It appeared that formerly there had been plenty of game, but it had been greatly reduced by white hunters, and the remainder exterminated by the native themselves, most of them being in possession of firearms. There was, therefore, none of their natural kind of prey remaining to the lions, which had become a very serious menace, not only to the live-stock, but to the villagers themselves. It is very unusual to find anything of the kind occurring in a district well stocked with game.

There are few sportsmen worthy of the name, I think, who would not consider a game country destitute of its lions and leopards rather a poor place.

Carnivorous animals are not subject to the epidemic diseases which at various times have destroyed large numbers of the ungulates of Africa. They are, however, as has been noted, delicate during youth, and some species are liable to contract the skin complaints which afflict their domestic relatives.

* Extract from the Yearbook of Agricultural Department, U.S.A. for 1908, by A. K. Fisher. 


\section{CHAPTER II}

\section{THE LION}

Probably there is no wild animal in creation concerning which so much has been written as the lion, and, seeing how thoroughly his habits have been described by those best qualified to speak of them, little appears left to add. Nevertheless, no work on the subject of African animals would be complete did it not include some remarks upon the ways of this terrible meat-eating cat, whose name in whatever dialect spoken is uttered with bated breath by the dusky inhabitants of the country wherein he dwells, and whose voice, echoing at night from the depths of the lonely forest, instantly stills the chatter round every camp fire. Originally, the lion was probably entirely a northern animal, but he entered Africa many long ages ago, and has since made that continent so much his home, that his name is habitually associated with it, rather than with Europe, whence he has long vanished, or with Asia, where he now lingers locally, and in diminishing numbers.

At the present day lions have been exterminated through human agency south of the Orange River, but in south Africa they exist in the northern and eastern Transvaal, Swaziland, Zululand, Rhodesia, Portuguese West and East Africa, Bechuanaland, and what was formerly German South West Africa. North of the Zambezi they are to be me with in all the less settled areas of the continent, where game is sufficiently plentiful, and the surroundings are not too unsuited to their habits.

Though much has been written descriptive of different local races of lions, considerable observation of them 
in one area has led the writer, at least, to the belief that the lack of uniformity exhibited in the presence or absence of mane, varying distinctness of spots in some adults, relative lengths of tail and so on, are in fact merely so many individual or family characteristics, dependent perhaps upon slight differences in their surroundings. In the neighbourhood of the Sabi River, for instance, in the north-east Transvaal, where the nights in winter are very cold, practically all the adult male lions are possessed of large bushy manes, sometimes yellow, but more often black or tawny. The bush being everywhere very thick and thorny, a forest life does not appear to have the hurtful influence on this hairy growth sometimes attributed to it. The animals bearing the blackest manes are usually the darkest in bodily colour, while a tawny or yellow mane is seldom seen except on a light-tinted animal. Cubs out of the same litter often show great variety in hue.

Some thirty miles north of the Sabi, where the country generally is comparatively open in character, and where, consequent on the absence of any large body of water, the night temperature is much more equable, male lions are either maneless or possessed of light-coloured manes of small size, while farther north again, near the large Olifants and Letaba Rivers, where conditions are more like those obtaining on the Sabi, the lions often have a full growth of hair on neck and shoulders, though seldom of very dark colour. I never saw a maneless lion in the Sabi bush, and seldom a fully maned one in the dry hot country lying between the great rivers. It should be added that, owing to the immense numbers of impala present in the Sabi bush, food is there very easy to obtain, while in the more open country to the north, lions certainly go hungry longer, and this high 
feeding or the reverse may perhaps affect the growth of hair to some degree.

As regards spotting, I have seen lionesses of mature age, in some cases quite old animals, killed, which had very distinctive markings on the limbs and underparts, while others again, out of the same troop, showed no indications whatever of spots. Tail measurements vary somewhat and do not always appear uniformly relative to the length of the body in different individuals. I have seen some lionesses so devoid of rufous tinge that they were almost grey in tone. Individual measurements and weight vary considerably also, and the handsomest beasts are by no means always the biggest. One of the finest maned lions killed on the Sabi was a comparatively small animal, while an immense brute shot farther north had practically no mane at all. Young cubs are covered with soft fur pitted with small dark spots, which begin to fade from the upper parts of the body very early in life. The milk canines are not replaced by the adult teeth until the animals are about a year old, and up to that age the young lion is comparatively helpless as regards fending for himself.

Three appears to be the usual number of a family ; but I once saw a lioness accompanied by four small cubs, and on another occasion two were met which had seven young animals of perhaps six months old with them. It seems, however, to be exceedingly uncommon for more than one or two of each litter to arrive at maturity, and, seeing that more than two cubs of over a year old are practically never found with one lioness, I should think the majority die before they attain that age, a result possibly due in some degree to teething or other infantile troubles. On two occasions young lions between six and twelve months old have been found 


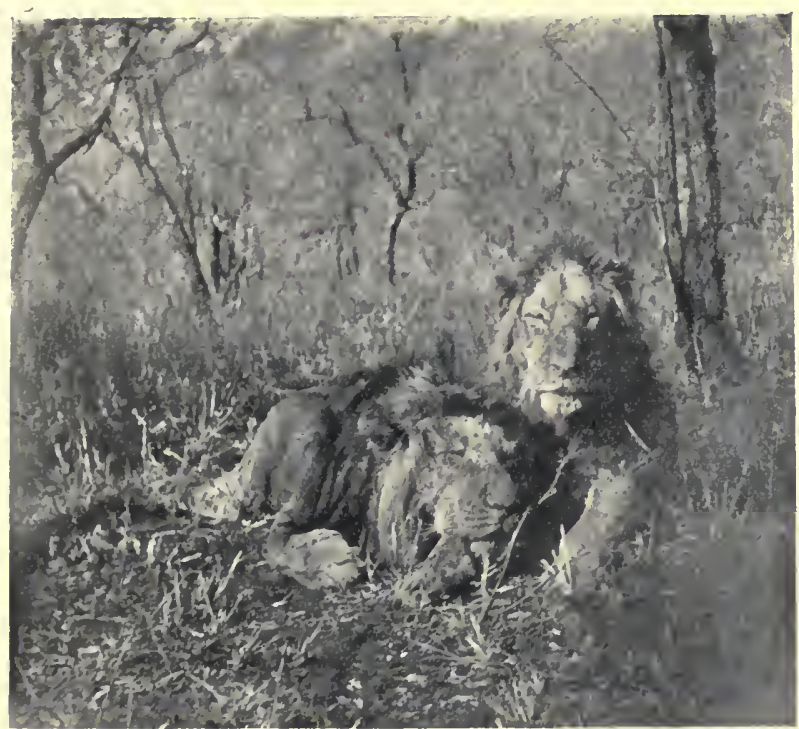

A PAIR OF SABI LIONS

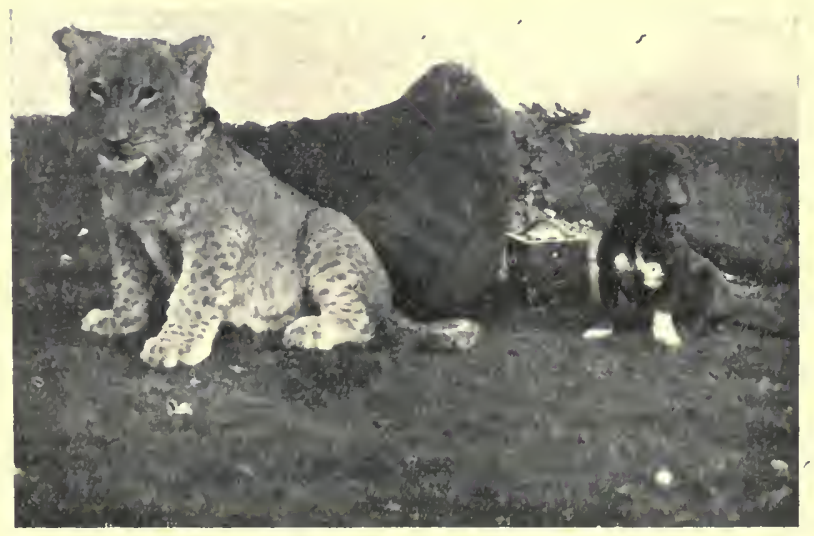

LION CUB

(Sabi Game Reserve) 
newly dead, without any obvious cause to account for their death.

Up to a year old the cubs are quite unfit to leave their mother; their teeth are fragile things, and, though as big and heavy as the biggest dogs, the young animals have still a long time before them ere they can take the field free from maternal guidance. Indeed, I believe that it takes eighteen months at least before they learn to kill their prey properly, and the care and trouble taken by the mother and her mate in teaching them to do so, as well as the amateur results attending their early efforts, are well known. To complete their education properly it is necessary and usual for the lioness to - devote all her energies to instructing them during this period, which would by no means be possible had she another and younger family demanding its share of protection; and it must be remembered that no animals regard previous offspring after the birth of fresh young ones. I do not think that, during twelve years of observation of lions' habits in the Reserve, any of the staff ever noticed a female accompanied by cubs of different ages.

The family life of lions is probably carried on as follows : a single lion and lioness are hunting together, and have a family of three cubs, say, two females and a male. At first a piece of dense bush, or the reeds near water, is used as a nursery, in which the little ones remain continuously concealed, while the parents, lying up with them by day, at night sally forth to seek food. Little tit-bits are, after a time, brought home for the youngsters, and as soon as they are strong enough, they begin to accompany their parents on short excursions, and the nursery is abandoned. After an animal has been killed, the cubs approach and take their share, the mother 
often assisting and instructing them. When they are about half-grown they begin to take their part in the killing, acting as seconds to their parents, who see that they come to no harm. It is at this time that great destruction is sometimes wrought among flocks of native sheep and goats by a family of lions. On one occasion while a native child was herding some of the former, about a mile from his village, and in broad daylight, a lioness with two well-grown cubs suddenly emerged from a neighbouring donga and fell upon them, killing the whole lot, about twenty in number, in a few minutes.

After the first year, when the large canine teeth have shown themselves, and the youngsters have attained not only to formidable size, but to considerable experience in hunting, the elders often allow them to do the killing, themselves standing by to direct and assist when necessary. An animal killed by young lions is always much mauled and torn, its appearance contrasting vividly with that of one killed in the clean and effective manner distinctive of seniors. On one occasion, when the stock at Sabi Bridge were unlucky enough to walk into a family of lions, a half-grown beast tried to tackle one of the donkeys by himself; but his efforts proved of so amateur a nature that the animal escaped with a few slight wounds. While they are still living with their parents, one out of the three cubs originally born, in all probability, will have died from some cause or another, and one male and one female remain. They are now practically grown up, and are able to take their full share of the work.

When the male is about three years old his mane is becoming developed, and, in consequence of trouble with his father, he leaves the family circle, and, joining forces with another bachelor a little older than himself, hence- 
forth knows it no more. The young males, presently feeling the want of mates, roar nightly; they roam the country, until after a while a young female leaves some neighbouring troop and joins them. $\mathcal{X}$ For a time the three hunt in amity, but sooner or later a serious quarrel and fight between the two gentlemen occurs. The vanquished may occasionally perish in the combat, but more frequently he departs torn and bleeding, to solace himself as best he may in the company of some fresh bachelor acquaintance, while the victor and his bride become the nucleus of a new troop. $\%$. It is not uncommon for more than one party of lions to be found hunting together, and, at certain times, several full-grown males will be found associated with a troop, though they are not likely to remain with it for very long.

Lionesses with young cubs are dangerous animals to approach, and will, under such circumstances, charge upon slight provocation. Mr. Wolhuter, one of the Sabi Rangers, once came on a large party of lions, three of the females having small cubs with them. His dogs pursued the latter, and he himself was successively charged by all three lionesses, though he described their rushes as demonstrations rather than determined attacks. Mr. Coryndon, when he was Administrator of Barotseland, was one day riding through perfectly open country when a lioness lying behind a small bush charged straight at him, and knocked him over, horse and all. Having done so, she immediately made off without attempting to do any further injury, and his impression was that she had young cubs somewhere close by.

Lions vary immensely in courage and temperament. A couple of years ago, two native constables on patrol in the game reserve came one evening upon three newly born lion cubs concealed in the reeds bordering a sand 
spruit. They picked them up and were carrying them away, when the lioness, which had been sleeping close by, discovered what was going on, and began to growl loudly. She made no attempt to charge, but contented herself with demonstrating from covert. The natives who were in the open, and had a good start, ran for some distance with the cubs, but, the lioness continuing to follow, still concealed in the bush near the stream, they became frightened, and, dropping their captures, made the best of their way home. Early in the morning; having obtained assistance, they proceeded once more to the spot, and to their surprise found two of the young animals lying half dead from cold, not far from where they had been dropped. The third had been taken away by the lioness, and her tracks were followed for over three miles. It was plain from these that she had been trotting all the time. In this case it seems likely that the mother was so nervous of human beings that not only did she refrain from attacking in the first instance, but was afraid to return to fetch the remainder of her offspring, both of which died a few days later of pneumonia, due to their exposure in the open during a frosty night.

A terrible adventure befell a trooper of the Transvaal Police during the winter of I908. He was on patrol with a companion in the north of the Zoutspansberg district, when two Boers were met, bringing, on a wagon, a couple of lion cubs, which they had picked up. Night being at hand, and it being considered probable that the bereaved lioness might make herself unpleasant, the whole party agreed to camp together. In the morning before the wagon had been inspanned, the police proceeded on their way. The senior, Eagle by name, a Canadian, and a keen hunter, instructed his companion BOOK I 
to proceed with the patrol, while he himself made a detour in hopes of coming across the lioness.

He had not gone far when the latter suddenly appeared from a clump of bush by the roadside, and crouched preparatory to springing. The horse refused to budge, whereupon the man fired from its back, breaking the lioness's shoulder. She immediately charged, and pulled Eagle from his saddle. He managed to maintain an upright position, and, being an exceptionally powerful man, grappled with the animal, grasping her by the throat with one hand, and kicking her with his heavy boots as she reared upon her hind legs. The lioness, for her part, was holding the man's other hand and wrist in her mouth, while her one available paw was over his shoulder, the claws tearing his back. Eagle was unable to say how long this remarkable struggle lasted; but the upshot of it was that the lioness, her severe wound beginning to tell, suddenly let go of him, and, going away a short distance, lay down. He then attempted to reach for his carbine, but found himself unable to do so, and then noticed for the first time that his right hand and arm were terribly mauled. Up to this moment he had felt no pain at all; but he now collapsed and fell to the ground, where he lay for some time until assistance happened to arrive, when the lioness was dispatched without further trouble. Eagle was taken down country on the Boer wagon, but, it being three days before his wounds could be properly treated, he died of blood poisoning shortly after his arrival in hospital.

There is no doubt that each troop or family party of lions keeps more or less to a certain district, which it patrols in a very regular manner. During eight years spent at Sabi Bridge considerable opportunities for observation in this respect have offered themselves. 
About three quarters of a mile west of the station a sand spruit-the Mutshidaka-joins the Sabi. We noticed that lions coming from the east always travelled up river along the banks of the Sabi, and patrolled as far as the Mutshidaka, following the course of this stream up for an uncertain distance, but eventually turning westwards, to re-appear at Sabi Bridge from the same direction as before at the end of a month or six weeks. I never knew these animals, which all belonged to one troop, patrol down the river, or cross the Mutshidaka to the west, nor indeed did they ever, to my knowledge, appear to come from any direction except the east.

There were three lions known to hunt the country some twelve miles up the Sabi from the station, i.e. west of it, and they sometimes patrolled eastwards to the Mutshidaka, but I never heard of their crossing that stream to our side of it, nor getting into the country hunted by the first-mentioned animals. At Tshokwana, twentyfive miles north of the Sabi, there existed a very wellknown troop, which for many months never moved out of a comparatively small area, and even the killing and wounding of members of it did not suffice to scare the others away from their favourite haunts. This particular family were great travellers within their district, and were continually on the move by day.

\section{CHAPTER III \\ LIONS \\ (continued)}

Lions when moving along at their ease have rather an ungainly appearance. They hold their heads very low, and their bodies swing from side to side ; but the moment they are alarmed, or their attention becomes excited, 
they are all alertness. I once had the opportunity of watching from very close quarters a couple of blackmaned lions approach a herd of impala, which were gazing and snorting at something in the opposite direction. The two lions walked slowly and majestically towards them, their heads held high, looking more like the noble beasts of story than any I ever saw before or since. There was no attempt at concealment from the time they emerged from the ravine twenty yards away, where they had been lying. Possibly they recognized that the prey was within their grasp, at any rate they simply walked straight towards it without hurry or noise. This was in the heat of the day, and no doubt lions, when hungry, do travel on right through the hours of daylight with only occasional short rests. In fact, it has fallen to the lot of all the Reserve staff at various times to follow the fresh tracks of lions almost from daylight to dark without once coming up with them. I recollect one day my old horse "Pompey," getting tired of standing alone with the reins over his head, took a short cut through the bush for home. He was followed by a couple of natives, whom he would not allow to get nearer than a hundred yards or so. Suddenly two lions made a rush at him, and he only just escaped by making a tremendous swerve. These animals, by their tracl:s, had been on the move, though it was three o'clock in tl:c afternoon and very hot.

Althcugh lions thus frequantly hunt throughout the day when hungry, and although, as the instances that have been quoted show, they may then, under certain circumstances, prove dangerous to man, as a rule they will give way before him. One of the rangers, while following lion tracks, once walked right into the middle of five while they were lying sound asleep in some long 
grass. The animals sprang up and rushed away, and so close were they that a lioness actually knocked one of the natives down with her hind-quarters; but they made no attempt to injure anyone, their energies appearing to be concentrated only upon escape. In my experience there is much less risk in following up a slightly wounded lion when he is in company with others, than when he is alone. He then seems to feel a sense of security from the neighbourhood of his fellows, whereas by himself he considers that he is in a "tight place," and must defeat his enemies at all cost. However, it is quite impossible to anticipate individual action. After having killed a lioness I followed her mate into some very thick bush, and got a snapshot at him, which it was assumed had missed. After pushing our way to the spot where he had been standing, the "boys" and myself were peering about to see which way he had gone, when he was heard to crash away from a thorn bush not five yards distant, behind which he had been lying down. Here traces of blood on the leaves proved that he had been wounded, and there is not the slightest doubt that had he been a courageous animal, or had he belonged to the other sex, one or other of us would have paid some penalty for our rashness.

Many natives display the utmost boldness in following wounded lions, and take risks which no experienced white man would care to undergo. In some cases this is due to want of imagination or experience, as is proved by the excessive caution the same men will display after they have received practical proof of a lion's powers. Wolhuter, in company with a young friend who had no experience of the animals, and five native trackers, all of whom were carrying spare rifles, once followed up a slightly wounded lioness. Feeling a severe attack of 
fever coming on, Wolhuter was obliged to turn back after going a few miles, but before he left the party he warned them to take no undue risks. However, sometimes with the aid of a very good and plucky dog which accompanied them, and sometimes by firing the clumps of reeds and grass in which she from time to time took shelter, they drove the lioness from one refuge to another without being able to get a shot at her, until she was worked up into a very bad temper indeed. At last they got her into an isolated patch of bush, whence she could not escape except in full view of the party. The dog went in, and was killed at once, upon which the white man formed his party in line about fifty yards from the edge of the covert, and, all having prepared themselves, they began to throw stones in.

Suddenly, like a streak of light, the lioness came. All fired, and all missed. In the wink of an eye she was on them, knocked the native at the end of the line over, and then seized the one next to him. The whole party apparently fell over in a heap, the white man getting entangled with a thorn bush, so that he could not use his rifle. Fortunately an old native hunter who happened to be farthest from the lioness, kept his head, and, inserting a fresh cartridge into his martini, shot the animal dead before anyone was fatally injured. I think all of them fully realized from that time that a wounded lion is not to be trifled with.

Once a lion has charged or has crouched ready for the rush, the hunter must rely on straight shooting alone to save him; but even should he unluckily miss, standing perfectly still may possibly benefit him. Ranger Healy was charged by a lioness which he missed when she was about twenty yards away, and coming fast, straight at him. He had no time to push another cartridge into 
his single-loading .400 , but he stood quite rigid. At the last moment, and when not more than three yards away, the animal suddenly swerved, and, passing round him to the left, turned when she had gone seven yards, and lay down facing him, her head on her paws and her tail twitching up and down. He then killed her. As a rule; lions run away after being wounded and only charge when followed up, but this cannot always be depended upon, and some, especially lionesses, will come almost on the shot.

One day the same ranger was riding along the path about a hundred yards ahead of his wagon, between which and himself were being driven seven pack donkeys. It was about 4 P.M. and he was not far from one of the rest camps which are built at intervals along most of the main routes in the Game Reserve, when he suddenly heard a cry of "lions!" and, turning round, saw a lion in the act of rushing at the donkeys, and not more than twenty yards from them.

On his firing, the animal stopped, and, wheeling about, walked quite slowly away, when a second bullet killed it. It proved to be a young adult male, very thin and wasted, its pads full of porcupine quills. No doubt porcupines are indirectly responsible for the deaths of quite a large number of lions; the latter are either specially fond of porcupine meat, or else young inexperienced animals, seeing in these rodents apparently defenceless and easily caught prey, are tempted to seize them. Upon being attacked, the porcupine, having recourse to his only method of defence, discharges his sharp quills into the body of his aggressor, and the paws, which are the instruments mainly used for seizing the prey, receive in their pads a large proportion of the spines. Keen as needles, these gradually work their way into the foot, and set 
up severe inflammation and festering, thereby partially or entirely preventing the lion from getting his livelihood.

Old lions are seldom found to be suffering in this way, unless, indeed, they have reached such a state of weakness that it may be presumed they were forced to take the first chance of an easy meal that offered. On the other hand, quite a considerable percentage of young lions and of those in the prime of life are discovered to be thus injured, and are often mere skin and bone, showing that they have been unable to hunt, or, at least, catch animals, on account of their injuries.

It appears to be very exceptional, however, for females to commit this imprudence, possibly because they are accustomed to hunt in company, and seldom go about alone, as males often do. A great many male lions have a few porcupine quills sticking in their bodies; but, if lucky enough to escape serious injury on the first occasion, they no doubt either give up the dangerous amusement, or take care that the more tender parts of their anatomy do not suffer. | Shortly after the conclusion of the war a party was travelling near the Olifants River, when a lion sprang from the side of the road upon a pack horse; so weak was he, however, that the horse threw him off with ease, and when shot he was found to be a mere skeleton, his feet in the most appalling state from the effects of porcupine quills. This was a lion in the early prime of life.

(As lions move through the bush on their rounds, they travel at a steady pace of about two and a half miles an hour, sometimes increasing it to a jog-trot of a mile or two more, and occasionally halting to roll. They clean their claws on tree trunks, and squares of bark may be seen thus pulled off at about four feet from the ground. 
They are capable of covering very large distances when on the move, and no doubt their activity is largely measured by the fulness or otherwise of their stomachs. They often appear to rest for a considerable time even during the night, so far as may be judged by the appearance of the "forms" next morning. Early cock-crow is a favourite drinking time, and, whether they have just enjoyed a meal or not, it seems usual for them to slake their thirst at least once in twenty-four hours, though seldom two nights running at the same place, at least where water is at all plentiful. Their methods of hunting and killing large animals have been so well described by Mr. Selous and others that it is not necessary to add anything to what they have said. They prey on all the greater herbivora with the exception of the pachyderms, though one instance of an attack on a fullgrown hippopotamus came under our notice. The dead victim is always dragged to the spot chosen for a meal, never carried unless very small.

When lions are hungry, very little comes amiss. One of the rangers, when camping out, had a lot of traps set for small wild cats, using rats as bait. A couple of lions one night went the complete round of the traps, and took every single bait away! While the writer was staying at one of the outlying picquets, a pair of lions came round the camp at night and tore up a sack which contained some porridge, besides breaking a calabash which had mealies in it, in both cases obviously with the object of getting at the contents. Much the same thing happened one night on the Sabi, when a party of lions demolished a sack of mealies which had been left in the bush some fifty yards from Major Fraser's wagon; on this occasion the greater part of the contents were simply strewn on the ground. Still more depraved 
was the taste of a lion which consumed entirely a very much soiled flannel shirt, the property of a native. Finding it laid out near the water wherein it was proposed on the morrow to wash it, he at once recognized and treated it as a delicacy.

Lions have no objection to carrion, indeed they rather prefer having their meat killed for them to being at the trouble of catching it for themselves; nor does the fact of the carcass being " high" (to put it mildly) hinder them in the least. I recollect once setting a number of traps round a dead horse to catch hyænas. About the third day the air was tainted for a very long distance down wind, and these scavengers began to collect from far and wide. On the next night a lion came; got caught for a time in one of the traps, and, whether in his natural annoyance thereat, or in resentment at having been led by the hyænas into a dangerous place, at once slew a couple of the unfortunate animals.

Lions have no scruples in bullying other and smaller members of the cat tribe when opportunity offers. On one occasion three of them had apparently lain up for the day under the shade of a tree, just where a female serval cat with three young ones had made her lair. The kittens being too small to run away, the lions killed all three, seemingly in pure wantonness, as they did not eat them. Another time I was following up some lions when I came to a spot where a leopard, having killed an impala, had been enjoying a meal. The tracks showed that one of the lions had made a rush, whereupon the rightful owner of the meat had made the best of his way up the nearest tree, there to remain angry but helpless, while the intruders were consuming his hardearned spoils.

It is a fortunate thing that full-grown lions are unable 
to climb; but a young and light lioness will get quite a good way up a tree, especially if the trunk be slightly aslant, and cubs can climb quite well. The latter often take refuge thus from dogs. I have a clear recollection of how I placed two little beasts of some six weeks old for safety in an enclosure, while a cage was being constructed for them. The enclosure had corrugated iron walls some ten feet high; but on returning in half an hour, I discovered one little wretch poised on the top, while the other had disappeared never to be seen again. He was traced over the river, which was three or four feet deep where he had crossed, and had a fairly strong current. Certainly the strength, intelligence and initiative shown was most remarkable in so young an animal.

/Lions are great swimmers, and have little of the rooted objection to water observable in domestic cats. They constantly cross both the Sabi and the Olifants Rivers, which are, both of them, deep and swift-running streams. Two instances out of many occur to me. One morning I left camp early, hearing two lions roaring loudly one on each side of the Sabi. After a fairly long walk I came on the tracks, and eventually put two male lions out of the reeds by the river-side. The one which I shot had evidently just crossed the river, as the water was dripping from all over his body. The stream here was deep in places, and the two, obviously mates, had been hunting, one along each bank, for part at least of the night. On another occasion Captain Slatter and I were following the spoor of two lions, that eventually led us right down to the Sabi, which they had crossed at a particularly wide and deep place, the river, moreover, being in partial flood at the time. We ourselves had to go more than a mile down stream before we could find a possible crossing. As these animals were hours in 
front of us it was certainly not alarm which induced them to go straight across the river just at the place where they happened first to strike it.

Cases of cannibalism occasionally occur. Mr. Healy, one of the Game Reserve rangers, came upon two lionesses and a lion near kilometre $\mathrm{ro} 2$ on the Selati Railway. $\mathrm{He}$ shot the lion, which was a young adult animal, and then proceeded to sit up over the carcass of a wildebeest which the animals had killed. This lay close to the foot of the tree in which Healy had taken up his position, while the remains of the lion were about a hundred yards distant. During the night one lioness returned; but, instead of coming back to the "kill," she lay up by the carcass of her mate, remaining there until shortly before dawn. In the morning it was found that she had eaten quite a lot of him. A message was sent to headquarters, and I arrived during the afternoon, when I personally saw what she had done. I sat up the following night, but the lioness returned no more.

Like all beasts of prey, lions are very much bolder by night than by day, perhaps feeling instinctively the advantage which they then have. It is on dark and rainy nights above all that they are to be feared; when the moon is near its full, and so sheds a brilliant light, they are little more dangerous than by day, and unless really hungry seem then to do little hunting. A story is told of how in Mashonaland, shortly after the rinderpest, when want of food had made these animals especially bold, several police troopers were at dinner one night in a hut. Hearing a disturbance among the horses, which were in a stable some ten yards distant, one of them went out to see what was the matter. He had scarcely stepped outside the door when a lion sprang upon and instantly killed him. 
A friend of mine, once sat up over a lion " kill." $\mathrm{He}$ had a shooting hole dug, of some three feet in depth, and covered over with logs of wood and branches. Having fallen asleep, he was suddenly awakened to the knowledge that at least one lion was sitting actually on the top of his hiding-place, within a few inches of his head! He was also somewhat disturbed at noticing that the weight of the beast was gradually breaking down the edges of the pit, so that the sand was running into it, and there seemed no small possibility of the whole roof shortly giving way. Luckily, the animal soon got up and walked over to the " kill," but the moment my friend put his head over the edge to try and get a shot, it returned with a rush, growling savagely. So soon as the head dropped out of sight, the lion went away; but the same thing happened on each occasion when the man showed himself, so that he spent rather an anxious time.

Ranger Duke, too, once spent a very bad night in the Game Reserve. He had camped at sundown by the bank of a small sand spruit, and had, as is our invariable custom when travelling with transport animals, erected a thorn fence within which he, his three natives, his horse, and his four donkeys, were enclosed. It was a pitch dark night, and presently a troop of lions came up the spruit and laid determined siege to him. One or another would every few minutes make a rush up to the "scherm " and try to get at the animals, only retreating before the shouts of the boys and the shots from the white man's rifle. The fire had gone out, and there was no wood to make a new one. The lions kept up an intermittent grunting close around, as if in the hope of stampeding the animals, which it took the united efforts of the whole party to restrain; it was, moreover, so intensely dark that nothing whatever could be seen. This unpleasant 
episode continued almost until dawn, which was naturally welcomed heartily by every one concerned. These lions apparently displayed no nervousness of human beings whatever.

Such conduct is, however, by no means invariable or even usual. Major Fraser was once encamped on the Letaba under very similar conditions. The night was very dark and rain was falling. The slumber of no one was disturbed; but in the morning the impressions in the soft ground showed that some lions had crept close up and had then sprung back as if alarmed, apparently repeating the proceeding several times before departing. Major Fraser believed that the bells which were hung round the donkeys' necks had the effect of scaring away the marauders, and I have known this occur in the case of trek oxen, one of which usually has a bell attached to his neck, so that the animals may not be lost when grazing in the bush. In former days, when wagons used to proceed by road through the low country from Delagoa Bay to Lydenburg, certain places along the route had a very bad reputation. In order to avoid the tsetse fly it was necessary to trek by night part of the way, and, near the Entumeni River, lions would often spring on the span and kill one of the oxen while actually travelling. This they did, moreover, with complete impunity, because, fearing the fly, the transport riders were forced to push on through the belt before morning, and so had no time to stop and punish the marauders.

Purely game-eating lions, which have little or no experience of man and his domestic animals, are certainly, as a rule, comparatively timid, even at night, when in human presence; but it is almost impossible to anticipate how different individuals or parties will act. Mr. Healy once tied up a goat and sat over it at a kraal where, 
during the two previous nights, lions had made unsuccessful attempts on the native stock. About 2 A.M. the lions arrived, and could be heard grunting and walking about quite close. Although the goat bleated continuously they took not the slightest notice of it, but moved into the village and round the huts, even lying down and rolling when they found a soft place, but always keeping away from the actual spot where Healy sat, so that he never got even a glimpse of them. After an hour or so they went quietly off. The natives said that they could "smell the gun!"

When forcing their way into a cattle or goat pen at night lions do not jump or climb over it, but attempt to push their way through underneath, and it is surprising how dense a wall of branches, or even of thorns, they can penetrate, if given time patiently to push and pull aside the obstructions. A barbed wire fence, being an impediment strange to an inexperienced lion, often gives him pause, and one morning at Sabi Bridge the tracks showed how, during the night, a lion had patrolled round and round the five-strand fence without being able to summon the confidence to cross it, although it was very loose in several places. In escaping when alarmed, lions will, as Mr. Selous points out, dash over or through almost any kind of obstacle.

Sitting up at night over a "kill " is often interesting as a means of observing the habits and methods of these cats. Two lionesses and a lion returned to the carcass of a waterbuck over which one of the rangers was sitting. $\mathrm{He}$ watched their movements for a long time before firing, assisted by the light of a quarter moon. The smaller of the lionesses kept both the others from the meat, chasing them away whenever they attempted to approach. After a time the ranger killed the small 
lioness, and badly wounded the other, which crawled away. The lion at first rushed off, but presently returned and commenced to run round the body of his dead mate with every sign of agitation, uttering a low, moaning noise. Whenever his path led him close to her, he shied off exactly like a horse, stood looking intently for a moment or two, and then continued his movements. On being fired at he decamped for good.

I once sat up at a place where, in the morning, a troop of lions had been disturbed, and two of them, including a lioness, killed. It was hoped that her mate might perhaps come back during the night to seek her, as he would very likely have done had she been his only companion; there being, however, two other lionesses in the party, he perhaps did not feel sufficiently lonely, and so the vigil was a vain one. During the hunt the lions had been scattered in different directions, and about ro P.M. began to call to each other. One lioness first began roaring about a mile to the east, followed quickly by another a similar distance to the south. After a time the male, apparently lying in a sand spruit some 500 yards from where I was stationed, began to answer, but, while the two lionesses roared almost continuously through the night, he contented himself with uttering single deep grunts at irregular intervals, his tones being easily distinguishable in their deeper and rougher note from those of his mates. Towards morning the whole party joined forces, and about dawn went away up the sandspruit, roaring loudly in chorus.

The distance at which lions may be heard, varies, of course, according to the direction of the wind, the state of the atmosphere, the nature of the country, and the position in which the animal happens to be standing relative to the listener. At dawn on a still morning, 
which is likewise the time at which they are most frequently heard, the sound undoubtedly carries a very long distance. I remember going after some lions from a camp where I had been sleeping, and which was five miles from home. The animals were roaring in unison a mile away on the opposite side of camp from the station, but the people there told me, on my return, that they had heard them distinctly. It is often very hard indeed to gauge how far a lion may be distant, from the sound of his voice. Often an animal which is believed to be quite close, in reality is several miles distant; while it happens now and then that a faint sigh or grunt, which seems to come from far away, actually proceeds from one which is close at hand.

Lions, of course, do not roar, or, in fact, make any sound at all when working up to game. No mice could be more silent than they are when thus employed. But when the conditions of the chase appear to demand that the quarry shall be stampeded or driven in a required direction, to a spot, for instance, where other members of the troop may be lying in wait, a very great deal of noise is sometimes made. Two lionesses once tried to stampede my trek oxen out of camp in the middle of the night. They were afraid to come very near, as the natives were awake, and the dogs barking. Therefore, while one made a circuit of the camp and lay near the path on the down wind side in perfect silence, the other, letting the oxen get her scent, roared loudly and continuously for a long time. In general lions roar after killing, perhaps to summon other members of the troop which may have gone in some other direction. In going to and returning from water they are generally noisy while-especially where unused to being disturbed-they frequently (perhaps usually) utter a few grunts and an occasional BOOK I 
roar preparatory to lying up for the day. On dull, cool mornings I have heard them up to Io A.M.

Various writers have expressed their opinions as to the majesty or otherwise of the lion's roar. I suppose it appeals to different people in different ways, and according to the circumstances under which it is heard; but there can at least be no doubt that it is something quite unique, and once heard cannot easily be forgotten. Personally I think nothing can be more impressive in the dead of a night spent amid some desolate African wilderness than the long-drawn cadence of the opening note rising and falling, and then merging into the succession of deep bass "woofs" which become fainter and fainter until they are scarcely audible sighs. When a number of lions roar in chorus the very earth seems to vibrate with the volume of sound, and the contrast with the dead stillness which follows is very remarkable. There is no doubt that, after a certain amount of practice, the ear learns to pick out the lion's voice, however faint and far removed it may be, among any number of conflicting noises and bush calls which, from their nearness, would, it might be supposed, easily drown it.

\section{CHAPTER IV \\ THE LION \\ (continued)}

Lions, when disturbed during the day by human beings, act according to their previous experience. If they are unaccustomed to being hunted they give place slowly, and, as it were, under protest, walking away with frequent halts to look back, and increasing their pace only when out of sight. But, where they have 
learned to dread man they often spring up and dash off at full gallop without a backward glance, uttering a succession of rumbling grunts as they go. When lying up by day lions like to hide themselves in some thick patch of bush, reeds, or grass, where the surrounding country is open or only lightly forested, that they may see all round while themselves concealed; but where the forest is everywhere dense they usually prefer to lie under some small bush or tree in the middle of the most open space they can find, thus placing field of view before concealment. , When lying down, even right in the open, they are often extremely hard to see, and are sometimes betrayed only by their black-tipped ears.

Like other beasts of prey, Nature has so fashioned these cats that they are able to go for considerable periods without food. Therefore, excepting in places where game is so numerous as to be caught with little exertion, it seems probable that the number of creatures destroyed by a single lion in a year is less than is generally imagined.

In South Africa cases of man-eating have always been comparatively rare, probably in consequence of the bold and virile nature of most of the native tribes, who would seldom permit the destruction even of a goat to pass unpunished. There are, however, a few stories, dating from the days before the white men came, still current in the Transvaal low veld, showing that lions had then considerably less respect for man than at the present day. A tale is related of how a lion once got into a native hut which contained a small child, the mother having either managed to make her escape, or being absent at the time. The villagers set fire to the wattle and grass walls, whereupon the lion escaped through the roof. The child was burned to death.

The only proved local case of man-eating which I 
know of in recent years occurred during the war, at Sabi Bridge. A picket of an irregular mounted corps had just arrived to take up permanent quarters and were bivouacking in the open round a fire. One of their number (Smart by name) was on sentry duty, and had apparently gone a few paces away from the fire when a lion sprang on him and carried him off. His cries aroused his comrades, who, seizing their rifles, fired a volley in the direction of the sounds, causing the lion to drop the man and make off for the time being. Though uninjured by the bullets, Smart died a few days later from the wounds inflicted by the lion. Undeterred by its reception, the animal returned some hours afterwards, this time visiting the natives' fire, and succeeded in abstracting one of the sleeping forms without arousing anybody. Luck being with it, it got the victim safely away and ate him. It is satisfactory to relate that this dangerous brute was killed a few weeks subsequently by the well-known hunter, Mr. Francis, who at that time was serving with the corps in question.

Man-eating lions in Africa do not seem so often old and worn-out as tigers pursuing this means of earning a livelihood are said to be in India. The lion mentioned above was a fine black-maned beast in the prime of life, and the notorious man-eaters of Tsavo were both in the full flush of health and strength. Nevertheless, lions killed while making night attacks on native goats have frequently been found very old and almost toothless, and these, no doubt, would have become man-eaters, given the opportunity. In the story I am about to relate, although one of the lions was certainly old, he was, nevertheless, possessed of full vigour, while his companion was quite a young animal, so far as could be judged. This incident has been recorded before, but is so very 
unique and altogether remarkable, that, especially as I can vouch for the exact truth of every one of the facts, I make no apology for telling it again.

In August I903, Mr. Wolhuter, one of the Transvaal Game Reserve rangers, was returning from a month's patrol to the Olifants River, and had arrived within two days' march of the Sabi. He had pushed on alone ahead of his natives and pack donkeys in order to reach the nearest police picket, if possible before night-fall. However, darkness found him still some three miles from his destination, riding along a path by the side of a reed-bordered stream, accompanied only by his big dog "Bull." As he rode through the dry bed of the spruit where the path crossed it in one of its windings, he saw something move out of the reeds and melt away into the darkness ahead. A few yards further on the dog rushed forward barking, and again an indistinct form moved ąway.

Supposing it to be a buck of some kind, Wolhuter rode on without taking any special notice of the incident ; but a few minutes afterwards he suddenly saw the shape again, this time apparently approaching. He had scarcely time to reflect that this was an odd action on the part of a reedbuck, when he became aware that it was no antelope, but a lion in the act of crouching for a spring. Pulling his horse sharp to the left just as the lion rushed, he caused the latter partially to miss his mark, but the claws tore down the horse's quarters, and the terrified animal, making a strenuous leap forward, shot Wolhuter over its right shoulder straight into the jaws of a second lion, which had been coming up from behind. Horse, man and rifle all went in different directions. The horse made off at full speed, followed by the first lion, which in turn was pursued by the dog. The man said 
afterwards that he never touched the ground at all, as the lion seemed to catch him in mid-air, the first thing he realized being that it was trotting off with him down the path. He was held firmly by the right shoulder, and, lying on his back, his face was on a level with the brute's neck, while his legs were dragging along under its body.

It was a desperate predicament, and, so soon as he was able to collect his thoughts a little, his mind kept dwelling on whether he would be killed outright or tortured first. He saw no hope of escape. The pain he describes as acute, which is contrary to the related experiences of Livingstone and others. However, being a very cool and experienced man, and full of "grit," he presently began to cast about for some method of saving himself. The mind works quickly in such cases, and suddenly he remembered his sheath knife, an ordinary six-inch blade which was carried in an open leather case on the back of his belt. Reaching underneath himself with his left hand, he discovered that the knife had fortunately not been lost during the fall and the subsequent dragging, so, pulling it out, he concentrated every energy on holding tight on to it, and awaited a favourable opportunity.

Fortune favours the brave, and his chance came when the lion, after going with him about I $_{5} 0$ yards, laid him down under a small tree, either for the purpose of shifting its grip, or of commencing operations. Feeling very carefully behind the left shoulder for what he judged to be a vital spot, Wolhuter then struck a couple of back-handed blows with all his force, using, of course, his left hand. It turned out subsequently that each of these strokes reached the heart. The lion remained stock still for a second, and Wolhuter then plunged the knife upwards into the throat. At this the animal, 
now streaming with blood, sprang back several yards and remained facing him. Wolhuter scrambled to his feet, and for what seemed to him hours, but was, no doubt, little more than a second or two, man and beast stood facing one another, the latter silent, and the former, with some hazy idea of the power of the human voice, calling it all the bad names he could think of. The tension was relieved by the lion turning and walking slowly away to a spot some thirty yards distant, where after a few groans, it expired.

Wolhuter meantime made shift to climb the tree under which the incident had taken place, a task not made any easier by his mangled arm. Having painfully settled himself in the lower branches he began to feel faint, and, fearing he would fall, he secured himself as well as he could by the large handkerchief which he had been wearing round his neck. It was well that he had not remained on the ground, for soon the other lion returned from an unsuccessful chase after the horse, and, arriving at the point where the attack had been made, followed the spoor of Wolhuter and its mate to the foot of the tree. Whether it would have succeeded in pulling him from his perch or not is uncertain, the branch being not much more than ten feet from the ground, but at this moment the dog came up and began a furious assault on the lion from behind. This effectually kept the latter employed, as on each occasion when it turned to Wolhuter,, after having driven away the dog by a rush, it was only to find itself once more assailed in the rear.

While this was still going on, the "boys " and donkeys came on the scene. Guns were fired, lights brought, and Wolhuter released from his position. The three miles to camp he speaks of as one of the most appalling times he ever went through. He dressed his wounds as well 
as he could, with the assistance of his servants, on arrival there. Next morning the natives found the dead carcass of the lion, and brought in the horse, which, though but slightly injured, was never any use afterwards for bush work, its nerve being completely ruined. Wolhuter himself was carried down country, and arrived in Barberton Hospital about a week later.' A naturally strong constitution, and the fact of his being in very hard condition at the time of the accident, eventually pulled him through; but blood poisoning set in, as it almost invariably does when wounds received from carnivorous animals are not quickly and scientifically treated, and it was many months before he was able to resume his duties. Talking over the matter afterwards, Wolhuter gave it as his opinion that the lions were stalking the horse, and possibly were even unaware of his presence until he actually fell into the jaws of one of them. Almost certainly neither of these lions had ever tasted human flesh, such a thing as a native being carried away by a man-eater not having occurred in the district for many years.

Although it is a very exceptional thing to come across lions by daylight, unless one is actually hunting for them, newcomers to a game country always seem to expect to meet the animals at every turn, and their imagination often plays them curious pranks. A very young trooper of the Constabulary once arrived at Sabi Bridge in a state bordering on panic. He had met a lion in the middle of the path. Some doubt being felt on the matter, he was asked to describe it, and replied that it was as big as a bull, black, and had horns!

On another occasion a ganger on the railway came speeding on his trolley into the nearest station to say that he had been " held up " by three lions a mile down the 


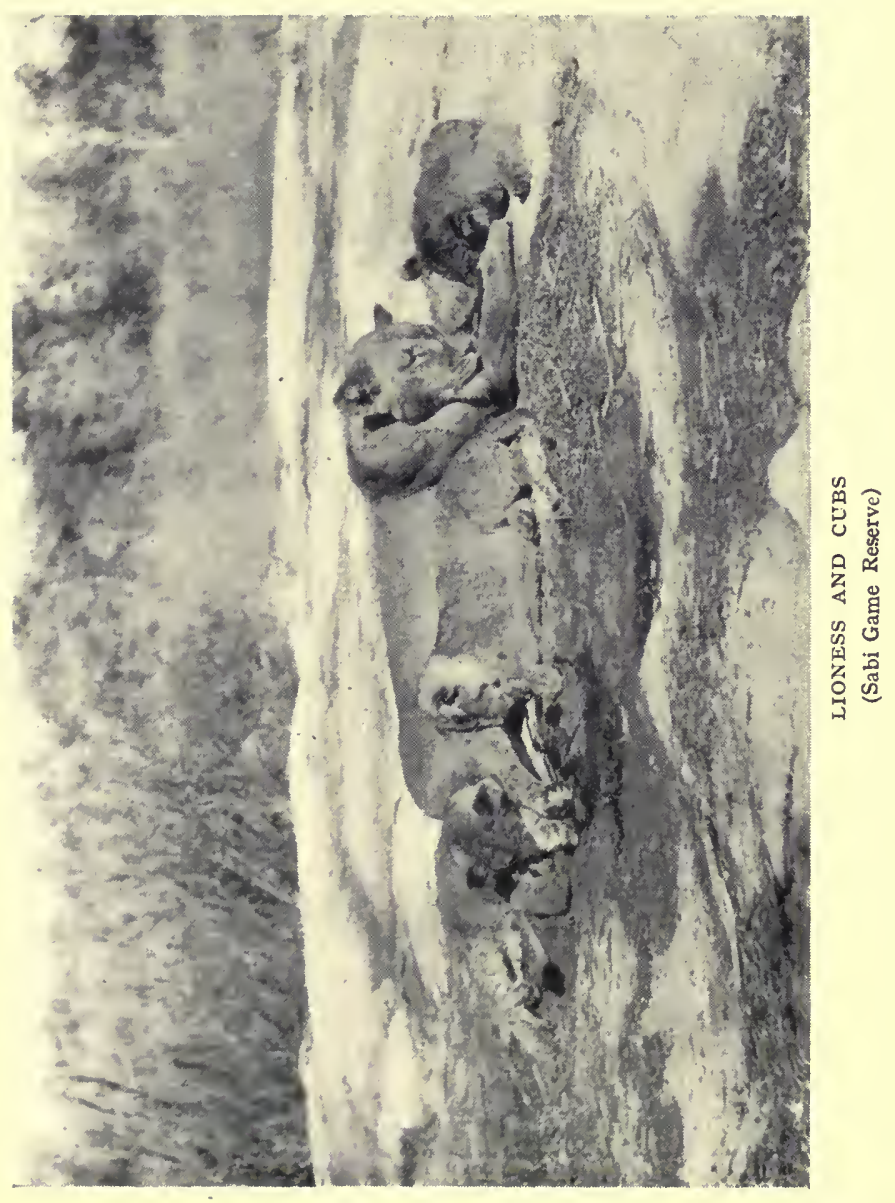


line. A number of the bolder spirits armed themselves and set forth ; but, on arriving at the place, found nothing but a father, mother and baby warthog quietly feeding. Another new hand was once riding from Komati Poort to one of the neighbouring stations. He became benighted, and described how he was so set about by lions that he was obliged to climb to the top of one of the old disused blockhouses and spend the night there, while the savage beasts raged about near the foot. Strange to say, the horse, which was tied up to a tree near by, was not only uninjured, but was so unobservant as apparently not to have noticed any sign of danger.

Warthogs and water buck cows especially seem to have the power of imposing upon the imagination of the novice in the Transvaal low veld, and I have known the grunting of an impala ram and even the booming of a ground hornbill send white men up trees with great rapidity. When the Selati Railway was being reconstructed in I909, the men on the first construction train saw the large troops of impala which are generally to be found about the line near Sabi Bridge. Nothing would make them believe that these animals, which, of course, they saw at some distance, were not lions, and they evidently were thoroughly convinced that their safety was due solely to the fact of being on the train. It is a remarkable thing that in the course of the hundreds, probably thousands, of times members of the Game Reserve staff travelled up and down the Selati line between I902 and I909, lions were not seen on more than three or four occasions |by day, and yet I can hardly recall a single instance of a stranger arriving by the same route at Sabi Bridge whose passage, according to his own account, had not been disputed by one or more of the animals. Verily, fancy has the power of 
leading even the most truth-loving of men along strange paths!

Should his career not be prematurely cut short, the ultimate fate of the lion is rather pathetic. Having for years roamed the forest, his supremacy unchallenged by any other of its wild denizens, he at length grows old ; his fangs become worn down to mere stumps, his bodily powers begin to fail, and he is no longer able to capture his ordinary prey. If a male, he has long ere this been driven away from the family party by younger and stronger rivals, and has since led a solitary and anxious existence. At length the time arrives when he finds himself compelled to exist only on such small mammals as he can pounce on and easily kill ; he becomes gaunter and weaker day by day, until, unable to seek food of any kind, he lays himself down, a sad spectacle of departed glory, and a prey for the hyæna, the jackal, and the vulture. Females remain longer associated with their comrades than males; but they, too, at last become unfitted for the strenuous wandering life, and their end is the same as that of the other sex.

\section{CHAPTER V \\ THE LEOPARD}

THE leopard is the most widely distributed of all the larger cats, being found at the present day throughout a considerable portion of Asia and most of Africa.

Thanks to its intensely secretive and strictly nocturnal nabits, as well as to its natural cunning and its comprehensive diet, it is always the last of the larger carnivora to vanish from areas openedup by civilization, and long survives the final disappearance of the big game. 
Seeing that individual leopards are so intensely local in habit, and seldom, unless forced by hunger or other cause, leave their own particular section of hill or forest land, it is remarkable how very slight has been the variation in type, not only throughout Africa itself, but between the animals native to that continent, and those of Asia.

In the north-eastern Transvaal there are two types of leopards, the extremes of each variety being very distinct from one another. That found in the hot, low-lying bush country is a long, lanky animal, rufous in general coloration, having a short coat and relatively small and clearly defined rosettes; it is known to the natives as "m'balana" (the small spotted). The other, a native of the hill country to the west, and met with at a height of about 2000 feet and over, is of a lighter hue ; the spots are larger and less distinct, while the hair is much longer. The animal itself is, I think, usually rather heavier, though possibly not quite so long in the body as its low country brother. The natives call it "Idzimba." However, I am convinced that these superficial differences merely represent the result of possibly a few generations of adaptation to surroundings. At all events, the nearer they are met with to the hills, the more closely do the leopards resemble the upland type, and vice versa. Cases of melanism* occur occasionally, though far less often in Africa than in Asia. Among many hundreds of leopard skins which I have seen in the eastern Transvaal, I never noticed one showing the least tendency in that direction.

In all forest countries which are well stocked with their natural food, leopards are undoubtedly much more numerous than the traveller, as the result of mere casual observation, might suppose to be the case. They are

* Entirely black animals. 
seldom seen, and never heard by day. Accustomed to lie up in the densest thickets, they slip silently away at the first hint of approaching danger; and it is only when accompanied by dogs, or by the merest chance, that the hunter happens upon one during his wandering through the bush. In the Sabi, the sandy bed of almost every dry spruit bears daily witness to the patrolling of one or a pair of leopards during the past hours of darkness, and it is remarkable how individuals cling each to his or her own section of country. It has happened again and again that when a leopard has been accounted for in some piece of bush or sandspruit, where nightly tracks and numerous "kills" have long borne witness to his presence, the range has remained tenantless for a considerable period, perhaps even for months, though, should conditions be favourable, it has, sooner or later, been taken over by some new arrival, some animal which recognizes in it an improvement on a previous huntingground, or which, freed from maternal control, is setting up for itself.

During the dry season leopards seldom range far from the neighbourhood of the permanent water; but, as the spring rains fill the forest pools, and there is a general migration of the herbivorous animals from their relatively restricted winter quarters to the more ample feedinggrounds now open to them, the leopard, too, feels the necessity of a change of quarters. Rising from his lair in the reeds hard by the impalas' drinking-place, he stretches his limbs and rolls for the last time in the bed of rotten leaves under the shady tree-scene of many a hearty meal. Then, after a few stealthy glances round, he silently moves off inland to the neighbourhood of one of the small forest pools, where the adjacent dense thorn bush promises a secure day retreat and favourable night ambush. 
Leopards generally lie up during the day in the thickest covert they can find, reeds, bush, or long grass. When their lairs are rocky krantzes and kopjes, where the midday sun beats down upon the sparsely covered rocks so that the surface becomes almost red hot, they like to creep into caves and crevices, where they lie sheltered until the cool, dark hours arrive. In the Transvaal low country, where abundance of good bush covert exists, I have not found that leopards patronize the kopjes and rocky outcrops which are studded over the country at frequent intervals. Now and then they go to such spots at night in order to hunt the baboons which make their homes there; but apparently they do not favour them as day resorts, and far prefer the cool reed or bushclad banks of some forest pool or stream. Occasionally their day may be spent up some leafy tree, lying extended along one of the great horizontally-growing branches.

Leopards are essentially nocturnal beasts, and, of all the larger carnivora, are probably the least frequently encountered in daylight by the sportsman. Fortune smiled on one of the staff at Sabi Bridge, when he nearly walked on to one stretched asleep across a game track; but, his rifle being unloaded, he failed to live up to his opportunity. A similarly annoying episode occurred in my own experience. I was wheeling a bicycle through a difficult bit of road in Uganda, the gun-bearer fifty yards behind with the rifle, when a fine leopard walked out of the bush within a short stone's throw, and quietly crossed the road, either not seeing, or completely ignoring us. This was about II A.M. on a hot morning, a most unusual time for a leopard to be on the move.

One morning, three or four years ago, Ranger Healy and I were walking through the bush. Accompanying 
us was a little fox terrier, which, at a certain spot, began to nose about, and then ran into a thicket on the right of the path. After a few moments, Healy, who happened to be a little behind, saw it rush out, closely followed by a leopard. The dog dashed straight towards him, and its pursuer also came right on until only some five or six yards from Healy. It then, perhaps seeing him for the first time, stopped abruptly, and sprang behind a bush, where it received a crippling bullet. We subsequently discovered that this leopard had been lying up by a dead impala ewe. The little dog had no doubt got the wind of the meat, and so brought on itself the wrath of the rightful owner, which was either oblivious to or, suddenly awakened from sleep, unaware of our presence.

Leopards, when hungry, sometimes prowl about their area until they sight or wind an animal, and then stalk it, after the manner of lions and other cats, or they lie in wait near game tracks and drinking-places, now concealed in some dense thicket or clump of reeds, now extended along the overhanging branch of a tree, from which they drop upon their victim as it passes beneath. The death wound is inflicted by a bite which severs the jugular vein or the vertebræ at the back of the neck, and the carcass dragged to some convenient tangle of brake or beneath some bush. Having eaten as much as he can the leopard, towards morning, proceeds to the water to drink, but before doing so often takes the remains up a tree for safety, a necessary precaution where hungry jackals and hyænas are ever on the watch for the leavings of their betters.

Not only are leopards expert climbers, but they are able to drag comparatively heavy animals to the most surprising heights. I have seen a full grown impala 
ram, which, though cleaned, weighed as much as the leopard itself, stuck in a fork fully twenty feet from the ground. How such a feat is accomplished has always been a mystery to me; but a few days need be spent in the bush without coming across evidence of its successful performance. A hunter, whose experience in the eastern Transvaal was in past days second to none, relates having once seen a giraffe calf, which could not have weighed much less than 200 pounds, lying across a branch about twelve feet from the ground, and many other instances of the strength of these cats are well authenticated.

Though leopards will thus attack the young of even the giraffe, as is further recorded by Mr. Selous in his "African Nature Notes," and though the immature of practically all the larger antelopes occasionally fall victims, their prey consists, generally speaking, of animals not larger than a reedbuck. On a few occasions I have known full-grown kudu and waterbuck cows to be killed, and Colonel Roosevelt speaks of the death of a Grèvy zebra; but the larger horned ruminants are generally left alone. Once my grey horse "Pompey" came in from grazing with slight claw marks on his quarters, which, from their position and size, had undoubtedly been inflicted by a leopard. If the latter mistook "Pompey," who happened to be shod behind at the time, for some hornless individual of the antelope tribe, he was probably roughly disillusioned.

Although these cats certainly kill a large number of the smaller antelopes, such as reedbuck, impalas, bushbuck, duikers and so on, their food consists by no means entirely of buck. In fact the leopard is liberal in his ideas as to diet, and devours impartially almost any warm-blooded creature which be can overcome, be it 
mammal or bird. Baboons and monkeys, cane rats and other rodents, large and small, and of all sorts, are eaten, as well as guinea-fowl, francolins, and in fact any feathered creature which can be captured at night upon its roost, not even the larger birds of prey escaping. A leopard which clings closely throughout the year to some bush near the ranger's station on the Ngwanitzi River, and whose habits were carefully observed by the officer for several months, seems to have subsisted, during that time, entirely upon birds and small mammals; at any rate no trace of anything larger than a cane rat having been killed was ever noticed.

Leopards with porcupine quills sticking in their feet and bodies are occasionally brought to bag, but are never, in our experience, so thin and wasted as are lions in similar cases. Perhaps their method of hunting, consisting as it does so largely of lying quietly in wait for their prey, handicaps them less when thus crippled. Something, too, they may owe to their great natural cunning and activity, which enables them to elude the sharp spines, which form the porcupine's sole, but far from contemptible, method of defence. It is said that they hesitate to attack full-grown male warthogs and bush pigs, though they prey freely upon females and immature animals. As I have known large boars of both species put up a good fight even against lions, and a lioness actually killed by one of the former, this is quite likely to be the case. A solitary wild dog will be pounced on and devoured, but should a band of these bush pirates be encountered, the leopard will lose no time in seeking safety. No kinship with the viverrines is recognized, and remains of genet cats are not infrequently found, which obviously had formed meals for leopards. In such cases the fur had been 
scratched out and not eaten, as the hair of a buck would be.

Leopards as a rule prefer to kill their own meat, having a great liking for warm blood; but when pressed by hunger, have no objection to almost any kind of carrion, and often are taken in traps set for hyænas. Once, indeed, a female leopard met her fate when the bait for want of better, was actually the flesh of one of these rather unsavoury animals. They will return again and again to their own kill, regardless of its decay, until it is finished; but cannot be depended upon to do so on consecutive nights. Indeed, if the least suspicious of danger, it is possible that a leopard may allow several days to elapse ere he comes back, though eventually I think he may be relied upon to re-visit the spot, unless he happens accidentally to have met with and killed some new prey in the meantime. I once came on a kill about three days old and half consumed, but three more full nights had passed before the animal again came near it.

Like lions, leopards can go for a considerable time without food, and, to an even greater extent, believe in " making hay while the sun shines." Especially is this true of a leopardess with cubs. In such a case the toll exacted from a herd of impala, for example, will be measured only by the agility of the members in effecting their escape. Instances of a couple of impalas or reedbucks, killed apparently during the same onslaught by a single leopard are numerous; and should one of these savage little brutes succeed in entering a goat or sheep pen, it will not rest content until every one of the inmates has been disposed of. Since usually it takes the better part of a week for a leopard to consume entirely a fullgrown impala or reedbuck ram, pure lust of slaughter 
must be held responsible where several animals are destroyed at the same time, except, indeed, where a leopardess has one or more well-grown cubs to provide for.

African leopards are no less partial to dogs as articles of diet than are their congeners in India. Some years ago five curs, taken from native poachers, were at Ranger Wolhuter's camp by the Olifants River. At dusk they were fastened up for security to a log near the native fire. The night proved dark and drizzly, and a leopard, stealing silently into the camp, took three of them away, having, as was evident from the tracks, returned for them one by one. It was followed up and shot by the ranger, with the aid of his own dogs, on the following morning, and proved to be an old animal which for some time past had been in the habit of stealing the fowls from an adjacent kraal, climbing the trees at night and snatching them from the branches in which they were roosting. I have never heard of an authenticated case of a maneating leopard in South Africa, though stories are sometimes told by old natives of children having been taken in past days. The reason may lie in the fact that the natives would never permit any animal to survive a first offence of this nature.

Savage and formidable as the leopard undoubtedly is, he will not face large and courageous dogs by daylight if he can avoid it, and I recollect a couple of such animals, belonging to one of the rangers, pinning and holding a leopard until their master came up to dispatch it. Mr. Sanderson, who sometimes hunts leopards with his large pack of dogs, often finds very little left by the time he arrives on the scene. A leopard, in fact, acts very much like an ordinary domestic cat in face of dogs. Driven to bay in some corner, he can and will defy them, but should a way of apparent escape lie open he will take 
to flight, and, if caught before reaching a tree or thick covert, the advantage lies rather with his enemies, provided they know their business and are sufficiently powerful and determined. The Franciscan Fathers at the Baromo Monastery above Tete, on the Zambezi, used to own a very large and active cross-bred deerhound, which, they said, had accounted, by itself, for more than one leopard; but, generally speaking, the latter, with its four sets of sharp talons, holds an immense advantage over any single dog, and, even if over-weighted and borne down, can rip its enemy's body with its hind ones. A big dog's only chance is to pin the leopard by the back of the neck while still on the run, when he may succeed in crippling it before it can use its claws. Probably no dog, whatever its size, and no matter how courageous, stands a chance if taken unawares by a leopard.

When at bay the leopard is a most plucky and dangerous animal. Unlike a lion, he may be relied upon always to charge home; the possibility of his losing heart and stopping or swerving at the last moment is so slight as to be not worth reckoning upon. A large number of them have been trapped during the last eight years in the Transvaal Game Reserve, and I can hardly recall any instance in which, when followed up in the morning, the animal has not charged or attempted to do so. In order to lessen the chance of the captive releasing himself, the method has been to attach the iron trap firmly to a branch, which, while too light to afford purchase, is of sufficient size to leave a track easy to follow. Although the leopard, thus encumbered, can charge at no great speed, there exists the possibility that his sudden furious spring on first sighting his pursuer, may release his paw, if, for instance, he has been caught by one toe only; 
and this element of danger supplies an excitement to the work which would otherwise be lacking. I use the word "work" advisedly, for in a reserve all beasts of prey must to a certain extent be considered as enemies. They have to be treated as poachers, and, while conforming to the canons of sport so far as possible, we have not to lose sight of that fact. Therefore, while, against the lion, it is impossible to think of using any other weapon than the rifle, had we to depend upon fair shooting alone to keep down the increase of so stealthy and elusive a member of the cat tribe as the leopard, failure would certainly attend our efforts.

A large leopard which had killed a donkey foal close to Sabi Bridge was caught in a trap set at the kill, and two of the rangers went out next morning to dispatch it. It had taken the trap over a bank, or small ridge, on the other side of which lay a patch of reeds. Thinking it had gone into the latter for concealment, one of the men walked, rather casually, up the bank, and almost fell over the leopard, which was lying just on the other side. The moment the man appeared, the animal, which had been listening intently to its enemy's approach, made a rush, and all but reached him. Indeed, had to not leaped backwards with an agility as surprising he himself as it was to the onlookers, he would assuredly have been caught. The beast continued to come on at an astonishing rate, considering the handicap of trap and attached branch, and was stopped only with some difficulty.

On another occasion a trap had been set for hyænas near a river, and the ranger, coming along in the morning, found it had been dragged into some drift and tangle close to the bank. The soft sand showed so broad a spoor, that he jumped to the conclusion that a crocodile, 
ashore during the night, had taken the trap into the river, and, hoping to discover some trace of Government property, he got on his hands and knees and crawled along the long dark hippo tunnel down which the track led. After a time he came on the end of the chain, and, thinking that the crocodile had got free, caught hold of it in order to drag out the trap. The moment he touched the chain, a terrific growl came out of the darkness close ahead of him, and he heard the clanking of the iron. The time which he took to get out of that tunnel was remarkably short; but, if the branch to which the trap was fastened had not caught in the drift-wood, he would scarcely have been quick enough; as it was, the leopard emerged from the passage only a fraction of a second after the man, and it was doubtless a sufficiently narrow escape for the latter.

For its size it is probable that a wounded leopard is a more dangerous beast than even a lion in a similar case. Not only is he, as a rule, pluckier, but he is less ready to leave a prostrate enemy than is his larger cousin, and will go on biting and tearing until killed or driven off. In addition, he is far more agile, and, owing to his small size, presents a more difficult mark for the rifle when charging. Wolhuter, who shot one almost at his feet, said that the two points which specially remained fixed in his memory were the pace the beast came at and its insignificance as a target. A sportsman who recently was badly injured by a leopard in East Africa, remarked that his sensation was as though a glorified tennis ball was coming at him, and, so rapid was the onslaught, that he had not even time to pull the trigger before the beast was on him. Years ago in the eastern Transvaal, a party of hunters had driven a wounded leopard into some reeds, and while the others took their stations 


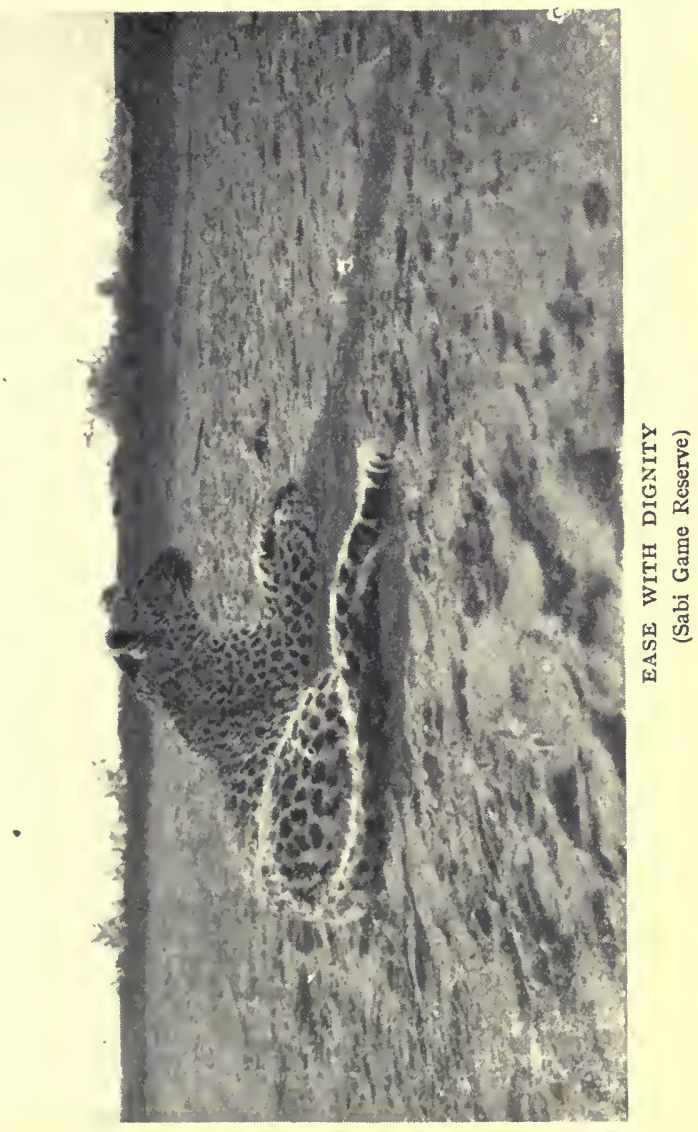


at various likely points, one of them mounted a large rock a few yards away, directly facing the creature's hiding-place. Suddenly the leopard charged out. The sportsman fired, but failed to stop it, and at one bound it sprang on to the rock and hurled him from it, falling on top of him and mauling him to death before assistance could arrive.

Leopards sometimes show very great sagacity, not only in avoiding traps set for them, but in abstracting the bait without getting caught. A leopardess with two cubs, on two successive nights, sprung a trap and took away the meat without injury to herself. On the third, a gun having in the meantime been set in addition, she pulled away the thick thorn fence built at the back of the kill, and dragged the latter away in safety. The touch of these animals is so delicate that the least rustiness of the springs of the gin spells failure, and they will avoid all obviously artificial roads to the trap, and often choose the most forbidding fence of thorns through which to wriggle to the meat. A wounded leopard at bay appears the very incarnation of ferocity; his ears are laid back low against his flat-looking head, his long white teeth gleam between the withdrawn, snarling lips, while his eyes, fixed with steady and sinister stare upon his enemy and filled with dull greenish-red light, glare murderous hate. Even when you know his back to be broken, his appearance is so little assuring that you have qualms about approaching close in order to give him the quieting shot.

Occasional instances of apparently unprovoked attacks occur. Some years ago one of the native policemen on patrol was at a village in the early morning. A leopard had been marked into a thicket close by, and some of the women seem to have thrown doubts on the constable's 
having the courage to go in with his assegais and drive him out. At all events, the man (a Swazi) entered, and almost immediately was attacked by the leopard, which he succeeded in beating off only affer he had received several nasty wounds. This animal is said to have been a male.

Leopards are good swimmers, and have no objection to crossing water. During the winter months the drifttangled islands in the middle of the Sabi are very favourite day resorts, especially for females with cubs. Sometimes quite a deep and relatively wide channel has to be crossed to reach these refuges, and, where the water is shallow and the current slight, I have known dead impalas dragged through to the islands. The prey is always hauled along by the neck, much after the custom usual with lions, and is seldom eaten exactly on the spot where it has been killed, but is dragged away to some favourite lair, which may be a hundred or more yards distant.

The secretive habits of these cats prevent their life history being studied in the manner possible with lions, but there is no doubt that, in a wild state, it is exceptional for more than one of each litter of cubs to arrive at maturity, and also that a leopardess spends as much time and patience in the instruction of her offspring as a lioness does. Pairs of leopards have been taken at the same bait, which were undoubtedly mother and daughter, or mother and son, though the younger animals had often very nearly attained to the size of their parents, and must have been in some cases quite eighteen months old. I have seldom known a leopardess accompanied by more than one well-grown cub, though two very small ones are often found with her.

Leopards are unsociable and solitary by nature, and on the whole they are silent creatures. Their ordinary 
cry is a sort of harsh cough, repeated several times in quick succession, and not unlike the sound made in sawing wood. When disturbed, or in the act of charging, they utter loud, harsh grunts, single or repeated, much resembling those made by a lion, though of less volume.

I have weighed a good number of low-country leopards immediately after death, and have found that the average weight of a full-grown male, in fair condition, does not much exceed one hundred pounds, although there have been animals which have turned the scale at I20 pounds. Females average from twenty pounds to thirty pounds less, and one full-grown member of the latter sex, in very poor condition, barely drew" fifty-three pounds. I have never weighed any hill leopards, but I should imagine that they would be a good deal heavier, judging from their appearance and measurements.

Like other cats, they are more easily disabled than any of the herbivora, and their power of recovery, though considerable, is also less. A leopardess shot on the Sabi had an old bullet wound in the shoulder; the skin had healed over it, but underneath the hole was full of pus, and the animal in very low condition. She had been wounded by Ranger Healy about five months previously.

Sitting up for a leopard over his kill at night is usually disappointing work. Unlike a lion, he never walks boldly up to the spot, but, on the contrary, creeps round in the shadows, closely scrutinizing the ground and investigating the branches of the trees, so that it is very difficult for the sportsman to escape detection, and on the least suspicion of danger the animal will vanish as silently as it came.

The feline attributes are exceptionally well marked in the leopard. His every movement is stealthy and 
sinuous. He will seldom cross a piece of open ground if, by making a detour, he can get to the other side under cover of bushes or grass. When the moment for action arrives, the latent strength concealed under the sleek velvet-like exterior shows itself, and the lithe body, now rigid as a bar of iron, is launched forward upon the unsuspicious victim almost with the rapidity and accuracy of a well-directed rifle bullet.

When caught young these animals often become very tame, showing much the same degree of affection, if affection it can be called, as is displayed by, domestic cats; but the wild nature is apt to show itself as the beast increases in age and size, and it is then best disposed of to the nearest zoological gardens or menagerie.

\section{CHA PTE R V I \\ SMALLER CATS}

The Serval. This very handsome cat ranges throughout the whole continent of Africa wherever the situation is suitable to its habits.

It is a long-legged, light-bodied creature, having a relatively short tail, a small head, and large ears. In height it stands about twenty inches at the shoulder; its length being nearly twice as much, exclusive of the tail, which measures about twelve. inches. It is handsomely marked with dark spots on a tawny groundwork; at the neck and shoulders these spots become lengthened into stripes, while the fur underneath the body is longer than that on the upper parts, and nearly white in colour. Cases of melanism * are much more frequent than amongst leopards. 
60

The serval preferably frequents the vicinity of ravines, dongas and vleis, covered with bush of not too dense a character, long grass, or reeds.

It is an expert climber, and when pursued by dogs

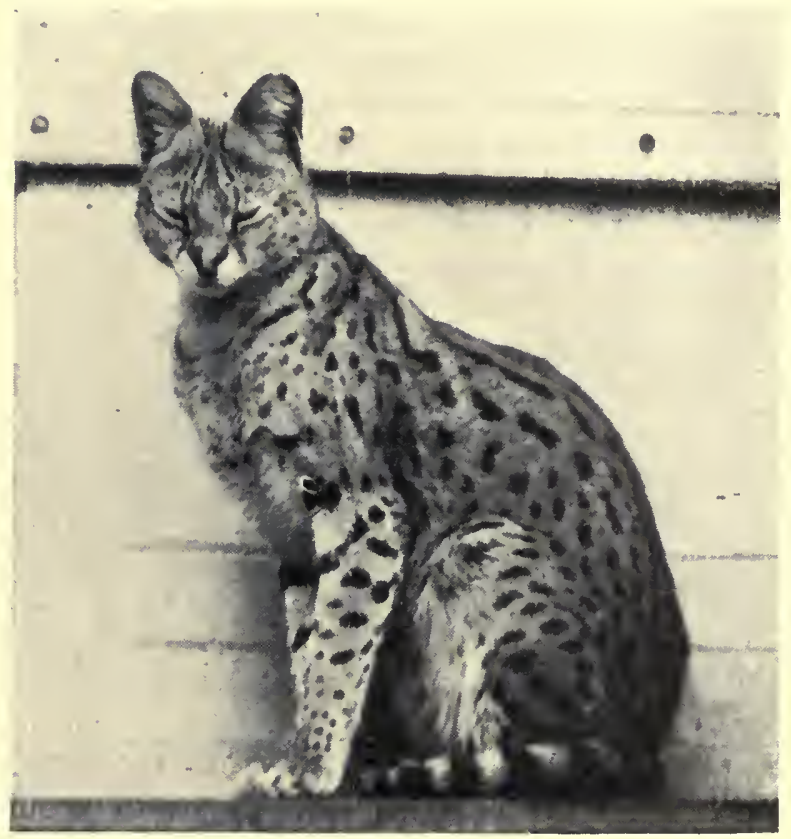

SERVAL

F. W. Bond, Photo.

usually takes refuge in a tree. It is essentially nocturnal in habit, and by day often lies concealed under bushes, or amidst long grass and reeds, at no great distance from water.

Its food consists of rodents from the size of large rats downwards, guinea-fowls, francolins, and other smaller birds, and occasionally the young of lesser antelopes 
such as duikers and steenbucks. It is a light animal for its height, and, though old males occasionally put up a good fight, can usually be tackled by any resolute dog even of small size. In fact, I have known medium-sized servals held, and once or twice killed single-handed by a plucky fox-terrier.

The cry of a serval is a shrill " Mwa, mwa " repeated seven or eight times in rapid succession; when at bay it spits and growls much like an ordinary domestic cat.

Servals do not lend themselves easily to domestication, and, no matter how young they may be taken, seldom overcome their repugnance to human beings, though they thrive well enough in captivity.

A small spotted variety inhabits west Africa.

The African Tiger Cat. This spotted species, which is similar in general shape, but superior in size to the ordinary domestic cat, is an inhabitant of the equatorial forest zone.

The Black-footed Wild Cat.-The general colour of this animal is pale tawny, but it is nearly white underneath and on the inside of the limbs ; its body is covered with small rounded dark'spots, which, on the nape and shoulders, fuse into vague longitudinal stripes. Its ears are of moderate length, slightly pointed; and the legs are encircled by three dark rings. The soles of the feet are black. The tail is relatively short, and black tipped.

This cat, which is rather less in size than the domestic animal, is only found in certain localities; in fact it appears to be confined to the. Kalahari Desert, Bechuanaland, and the west of the Orange Free State.

The African Wild Cat. This cat, of which the South African variety is known as the Kaffir cat, is distributed over the whole of Africa except the equatorial forest zone and the Sahara. During prehistoric times, its 
range included a large portion of Europe, and it is possible that the modern domestic cat originally was wholly or partly derived from the north-eastern form of the species. It is, at least, certain that the animal was domesticated and held sacred by the ancient Egyptians, as carcasses have been found in great numbers embalmed in the tombs of these people.

In colour the species is brownish grey, with slight transverse dark stripes on the body. The upper parts of the limbs and the tail are dark ringed, the tip of the latter and the lower portions of the former being usually more or less black. The head is dark with darker irregular markings ; there is a black spot in front of each eye, and the under parts are yellowish buff, spotted towards the front. Ears, rufous behind. The tail is rather less than half the length of the body. In size the animal is rather larger than a large domestic cat. The female is altogether lighter in colour and is less distinctly marked.

The Kaffir cat is nocturnal in habit, but is occasionally met with in the day-time, when the weather is cloudy and cool. It inhabits for preference lightly forested country, lying up in bushes or in deserted ant-bear holes during the day. Its food consists of birds and small mammals, and it is extremely destructive to game birds, as well as being a notorious raider of fowl roosts. For a long time I had a half-bred Kaffir cat at Sabi Bridge. In size he was slightly bigger than an ordinary domestic "tom" ; in colour he was bluish grey with typical wild cat markings. Although perfectly docile and gentle, he never quite lost some of the wild characteristics of his sire : disliked being handled, and slept during most of the day. However, he had become so far civilized that he never interfered with fowls, and was always on excellent terms with the numerous dogs of the station. 
He was very quick with snakes, and 1 have often seen him consuming the remains of a night adder and such smaller species in the early morning. Retribution eventually befell him, however, in the jaws of a large python.

On moonlight nights, or at dusk, these wild cats may often be seen hanging about in the near vicinity of human dwellings, and, while staying at Gondokoro, I put up one just after sunrise, in the compound behind the dâk bungalow and well within the outskirts of the village.

The Jungle CAT.-The jungle cat ranges from northeast Africa into Asia. It is about the size of the preceding species, and is of a uniform fawny colour with a very short tail.

The backs of the ears are rufous, and the limbs and tail have dusky bands, the latter with a black tip.

The Caracal. The caracal is much the most powerful of the smaller cats of Africa, and, in its long limbs, pencilled ears, and the shape of its teeth, is very much like the true lynxes of the northern hemisphere. In colour it is uniformly grizzled yellowish red, lighter below. The ears are pointed and bear at their ends long pencilled tufts of black hairs. There are traces of rufous spotting on the underparts, strongly in evidence in quite young animals, but tending to disappear with age. The height at the shoulder is about eighteen inches, and length of body about two and a half feet-tail about ten inches; but the caracal is a heavily built animal for its size; the limbs are massive and powerful, and it far exceeds in strength and capacity for destruction the taller and longer, but more lightly built, serval.

Its range comprises the whole continent of Africa wherever the surroundings are suitable.

The caracal may be encountered equally in fairly open, 
mountainous, or densely-bushed flat country. In the day-time, like other cats, it prefers to lie up in thick cover, but I have seen individuals asleep under a tree almost in the open. I noticed one standing in slight shade at $8 \mathrm{~A} . \mathrm{M}$. on a hot morning in summer, and at first mistook it for a steenbuck. Its food consists of birds of all kinds, even the larger birds of prey, which it attacks on their roosts at night. I have seen remains of the large and powerful tawny eagle undoubtedly killed by a caracal, and on one occasion came across those of a martial hawk eagle, largest and fiercest of all birds of prey in the eastern Transvaal, which apparently had met a like fate, though it must be admitted that there was some little doubt whether in this case a leopard had not been the aggressor. Besides birds, the caracal preys on all the small mammals and lesser antelopes, such as duikers and steenbucks, and the young of creatures of the size of impalas and reedbucks, together with sheep and goats when they offer themselves. When I was shooting on the hills near White River, a very large male caracal was killed, which proved to contain the greater part of a steenbuck. The incident occurred in a piece of thick bush, and I distinctly recollect Mr. Munnik, unable to see clearly through the covert, calling out that he had shot a lion cub, and our momentary anxiety-we were armed only with shot guns-lest the infuriated mother should suddenly appear upon the scene !

A dog must be both large and courageous to cope successfully single-handed with one of these powerful little cats; my Irish and fox terriers have often returned severely worsted from the fray. If pursued by dogs, however, they will usually take to trees, being expert climbers, and can then be easily shot. When at bay, they spit and growl after the fashion of most of the 
lesser cats, but normally their cry is not unlike that of the leopard, though pitched in a lower key.

Caracals are generally believed to be untamable, and, in fact, out of a good many young animals which I have kept in captivity at Sabi Bridge at various times, I never knew one which showed the least disposition to be friendly

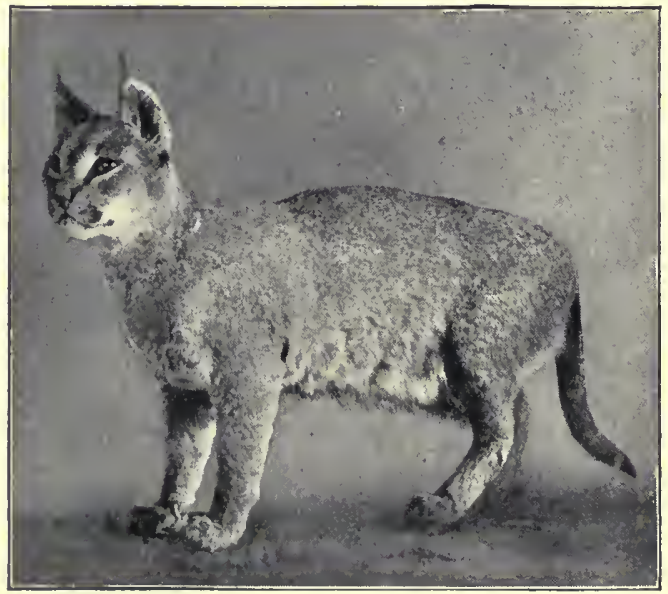

AFRICAN LYNX OR CARACAL

to human beings; but I met with an exception in Portuguese territory, where the wife of the Commandant of the Station at Muncha owned a nearly full-grown beast which lay in her lap and was in all respects perfectly amenable and docile with its mistress, and with some persons whom it knew, though it showed considerable antipathy to strange white men and to all natives. 


\section{CHAPTER VII}

THE HUNTING LEOPARD, OR CHITA

THE hunting leopard or chita is distinguished from all other cats by its lack of fully retractile claws, a circumstance which imposes upon it a manner of hunting its prey distinct from that employed by the remainder of the cats. It is a slenderly built, long-limbed animal, not so sinuous and graceful as the leopard, and fashioned for speed rather than for catlike agility. The tail is long and rather bushy, the spots are solid, and a slight mane or ruff decorates the neck. The head is small, the teeth are inferior in size to the leopard's, and the jaw is less powerful.

It inhabits most of the drier, less densely forested portions of the African continent, where game exists, and, like that of the lion and the caracal, its range extends into Asia; or perhaps it would be more correct to say that the species has extended, without pronounced change of type, from that continent into the Ethiopian region.

The hunting leopard is generally found in open, or lightly forested grass country. Thick bush, not being suited to its method of securing its prey, is avoided.

It is extremely secretive and shy by nature, and although perhaps comparatively numerous within a given area, it is surprising how seldom it is met with, considering that much of its hunting is done in the early morning and late evening. It is less nocturnal in habit than any of the other cats, and often ventures abroad in the day-time, especially in cool and cloudy weather. In a game country there is always the odd chance of coming across one of these animals, often under the most unlikely conditions. 
I was once in camp on the Sabi, and had just finished lunch on a particularly hot January day, when a chita came walking quietly out of the bush within thirty yards on his way down to drink at the river. Of course he saw us as soon as we noticed him, and had disappeared long before the rifle could be snatched up. Another time I had sent the wagon on ahead before sunrise, and, after a light breakfast, was cantering on to overtake it ; I could already see the unwieldy vehicle crawling along some 400 yards ahead, to the usual accompaniment of strident yells and whip cracking, and naturally an encounter with a beast of prey was the last thing in my mind. Suddenly something in the bush near the path caught my eye, and I became aware of a large chita slowly making his way along in the opposite direction to myself, quite unconscious of my presence, and less than fifty yards distant. I think on both these occasions a recent heavy meal had caused the animal to be less alert for the time, and possibly the same factor may have been accountable for the almost ridiculous ease with which chitas have sometimes been galloped down on horseback.

For a short distance this cat can certainly outstrip any living antelope, but its bolt is probably quickly shot, and I think if the game succeeds in getting sufficient start to keep ahead for the first few hundred yards, the chita seldom perseveres.

Chitas generally hunt in pairs, but family parties, consisting of the male, female, and one or two wellgrown cubs, are not infrequently noticed. They are far more sociable creatures than leopards, but less so than lions. The prey is stalked by moonlight, or in the early morning and late evening-though in cloudy weather any time of the day serves. In this preliminary work the chita displays all the stealth and cunning of his cousin 
the leopard, taking advantage not only of the wind, but of every sheltering bush and tuft of grass, as he crawls along glued flat to the ground. Arrived within convenient distance, he makes his rush like a flash of lightning, and has already covered probably half the intervening distance ere the unhappy victim has so much as raised its head. The prey is most likely pulled down before it has got into its stride; but, even should it get a fair start, for the first few hundred yards its pursuer can move at nearly double its pace, and its chance is a slender one.

Racing up alongside its quarry, the chita springs with unerring aim at the throat, or on to the back, when its weight and the pace at which both are moving bring pursuer and pursued headlong to the ground. The grip of the teeth is never relaxed; the claws, though they cannot be fixed firmly into the flesh as the leopard's are, nevertheless afford the chita a purchase, and the prey, bitten through the jugular, or with compressed windpipe, quickly surrenders its life.

Chitas are not so regular in returning to their kills as other cats. I think they will often come back once, but cannot be depended upon to do so, especially if they have been alarmed. Their usual practice seems to be to eat as much as they can, and then to go and drink at the nearest water. After this it is quite a matter of chance whether they return to lie up near the kill or not; if they do, they probably eat some of it the next night, but I never knew them come back to it after the second night ; no matter how much meat was remaining. They are, therefore, very destructive animals, much more so than leopards, and, relatively to their size and power, than lions. A large male chita was shot by a trap. gun set over his own kill-a young waterbuck- 
at Sabi Bridge. He had killed early in the morning, and had eaten a good deal of the meat. He returned and was shot about 9 the same night.

One afternoon about four o'clock I disturbed three of them lying up by the carcass of a reedbuck ewe which had been killed the same morning, but had not been touched. That night they returned and ate the whole of the hind-quarters, about one half of the trunk, and one fore-quarter, together with the meat of the head and neck. Two traps had been set, over which the animals had leaped to get at the meat; they released the springs, without damage to themselves, no doubt in the course of hauling out the carcass from the little fence which had been built round it. They never came back again, and hyænas finished the meat.

For the most part chitas prey upon antelopes up to the size of a reedbuck, and the immature of larger kinds, (occasionally on the hornless females and even the males of certain species, such as waterbuck and kudu). A fine waterbuck bull was found lying dead in the bush, life having been extinct, apparently, for about twentyfour hours. None of the meat was eaten, but the back tendons were almost bitten through ; there were scratches and tooth-marks all over the limbs and body, and the animal had bled to death from the severing of a large artery. Following the back tracks, we came to where they showed that a single chita had rushed on the buck as he was quietly walking along, pulled him down and rolled over with him on the ground. The big buck had then scrambled up and dashed madly off, the chita probably clinging to his back. A little further on they had fallen again, and then, rising a second time, the buck had dashed under the low-growing branches of a large tree, by this means apparently sweeping his assailant 
from his back and possibly injuring it, as it seemed to have made no further effort to pursue, and the waterbuck dropped a couple of hundred yards further on from loss of blood.

A pair of chitas pulled down and killed a full-grown tsessebe bull near Tshokwana in April I909, but I think both this case and that of the bull waterbuck were excep-

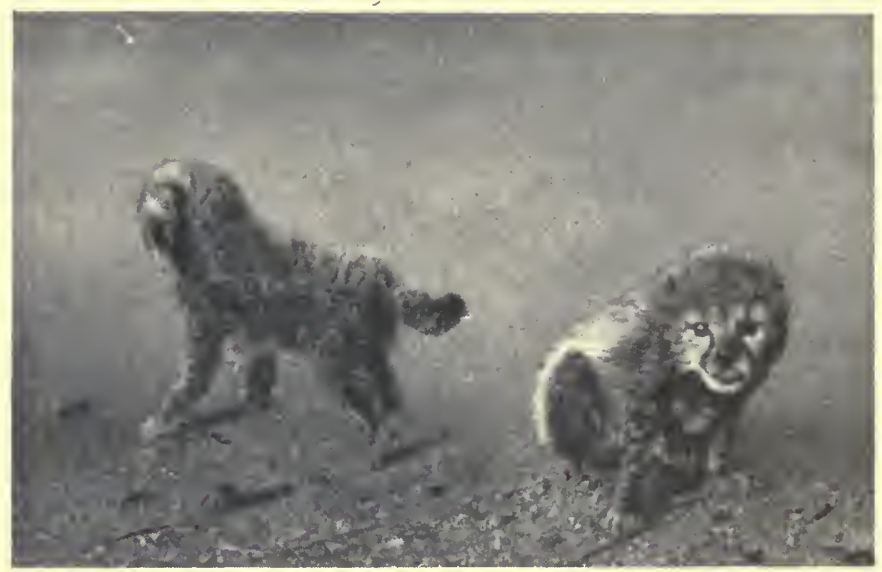

CHITA CUBS

(Sabi Game Reserve)

tional and I never heard of a full-grown individual of the more formidable species, sable, roan, wildebeest, or zebra, being interfered with. I do not think chitas care much for carrion, at all events I never heard of their eating it, and, from the manner in which they neglect their own kills, it is probable that they prefer not only to hunt their meat, but to eat it fairly fresh.

Several cases of cannibalism have been known. In I903, a native watcher, patrolling in the Game Reserve, came, one evening, on two chitas fighting in a clearing 
of the bush near the Crocodile River. He was frightened and ran back to his picket, but in the morning, consequent on his report, the white ranger went out and found a male chita lying dead on the spot. A reedbuck ram lay close by untouched; but the dead chita had a portion of its neck and shoulder eaten away. His revenge satisfied, the conqueror may have felt too sick to fall to on his legitimate prey. Major Fraser reported a similar case as having occurred in the Singwitsi section of the Game Reserve in I9o8, when a large male was killed and partially devoured by another. Perhaps in such cases as the above, where two males have contended over a "kill," the agitation of the struggle, combined with the taste of blood, have led the victor, while still under the influence of excitement, more or less unconsciously to follow his lifelong instinct of devouring what he has killed. As a rule, to all beasts of prey, the flesh of one of their own kind is the forbidden thing.

Though a ruthless hunter of his natural prey, the chita is perfectly inoffensive as regards man, and, when wounded, seldom shows fight, presenting in this respect a most remarkable contrast to his relative, the leopard. Apart from the seeking of his daily bread, he is gentle and timid in disposition, and is docile in captivity.

Owing to the formation of his claws, the full-grown chita is unfitted for tree climbing, though he sometimes springs into low-hanging branches, or up a sloping trunk when closely pursued by dogs and unable, through injury or other cause, to outdistance them. I believe that young animals, before their claws have become worn or blunted, can climb fairly well, and I once kept two small cubs at Sabi Bridge which ran up the walls of the large wire netting cage in which they were confined as easily as ordinary cats, and could even cling on to the 
roof. I also noticed that the semi-retractile claws of these cubs were quite as sharp as those of a true feline, and when one of them rushed at a terrier which had got into the cage, he struck at the dog with his forepaws as he charged, just as a domestic cat often does.

These young animals were caught near the Mlondozi Spruit in October I908, being then apparently about two weeks old; the mother was started out of some rocks by a couple of native policemen, and made off without attempting to defend the little ones, which attempted to follow her, but were quickly caught and picked up. They were covered on their upper part with long bluegrey silky hair, while the sides, tail, legs and the underneath parts of the body of each were coated with tawny fur, thickly pitted with dark solid spots. The eyes were dark brown, and the whites showed a good deal. The sound which they usually uttered was a bird-like chirp, sometimes followed by a purring noise. When annoyed they spat exactly like domestic cats.

At about two months old they had become very tame; but when I had them out for exercise in the yard one day something startled them, and they could then run so fast that they were recaptured with some difficulty. At three months old the pronounced greyness of the backs had begun to disappear, and the spotting had become general all over the bodies; the fur throughout was, however, much longer than in adult animals. The voices also altered, the bird-like chirps becoming changed into "mews" not unlike those uttered by domestic cats, and were curiously mixed with, and followed by, the short purring sound. About this time they began to take a strong and apparently not too benevolent interest in any small dogs and fowls which passed near their cage. Beside milk, the little creatures took flesh 
freely soon after their arrival, and later accepted anything in the way of raw meat offered them, consuming not only the flesh of antelopes and birds, but of leopards, civets, hyænas, and wild dogs, with complete impartiality. They were always very shy with strangers, but their own attendant could handle them readily.

The call of the adult animal is a kind of "chirping" or " mewing," a cat's "mew" cut short, as it were. When alarmed or annoyed it utters a deep growl.

\section{CHAPTER VIII}

\section{VIVERRINES :}

THE AFRICAN CIVET-GENETS-MUNGOOSES

Tiie African Civet. A full-grown male civet will measure some four feet in length, eighteen inches of this being taken up by the tail. The ground colour is yellowish grey ; there is usually a ridge of long black hairs forming a crest down the middle of the back. The body is covered with dark spots. The cheeks, throat, and limbs are black. The tail is ringed, with a black extremity. The ears are short, broad, and rounded, with white bases and black extremities. Glands are present on each side of the tail, and the scent obtained therefrom was formerly in considerable demand as an article of commerce.

The species extends through the tropical and subtropical regions of Africa, including the low-lying regions of the east coast as far south as Zululand. It favours rather thick bush, and, as a rule, is not met with in hilly country.

The civet is solitary and nocturnal in habit, and lies up by day in grass, bush, or the holes made by ant-bears 
and other large burrowing animals. It is strictly a ground animal, being, from the nature of its claws, unable to climb trees.

Its diet is a mixed one. At certain seasons its favourite food consists of a round red berry, containing a large stone, the product of the tree called by the local natives

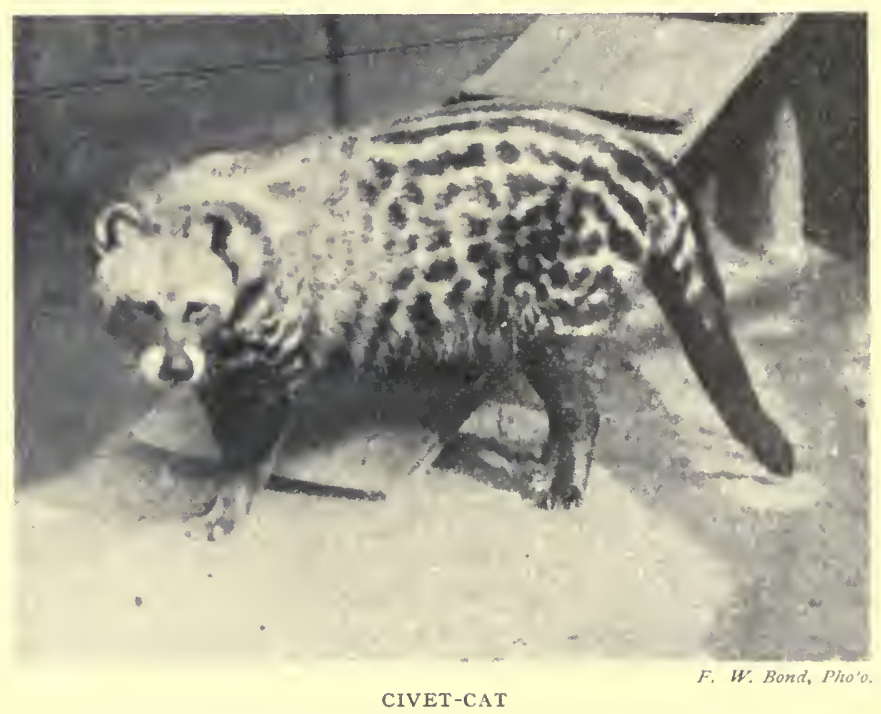

mpafa. This tree possesses a hooked thorn and an oval leaf, and the fruit is often eaten by the kaffirs in years of famine. White ants, large beetles, locusts, and other insects are also consumed, besides lizards and frogs, while a shelly insect found in great numbers on the surface of the ground after rain is eagerly devoured. Among mammals, the civet preys on rats, mice, and such small creatures as it can catch and overcome. Carrion is eaten freely. Traps baited with any kind of meat, 
no matter how old, attract civets, and they often come to leopard and other " kills " in the absence of the rightful owners. Did the animal restrict the items of its diet to the above, there would be no grievance against it; but unfortunately it is a deadly foe to all such bush francolins and other game birds as habitually nest or roost on the ground, kills hares and the newly born lambs of small buck, is a confirmed egg-eater, and occasionally a poultry thief. Therefore it has to be classed among the objectionable vermin, and dealt with as such. I once owned a large cat which, during her wanderings one night, was pounced on and killed by a mediumsized civet. She was found to have been seized by the back of the neck, and the spine was bitten through. All the blood had been sucked from the body. A trap was set, and the assailant, returning to its kill on the following night, paid the penalty of its deed.

Civets are capable of remaining for considerable periods without food. One caught on Ist June refused everything except water until the I $^{\text {th }}$ of that month, though it was tempted with many of its favourite articles of diet. On the last named date it drank a little milk, and later began to eat normally. It was afterwards found to have sustained an injury to the jaw; probably while being captured. Similar capacity for enduring hunger was recorded of another animal sent to the Transvaal Zoological Gardens, which was some time before it would accept the unaccustomed diet there put before it. When caught uninjured, and offered their usual food, civets generally do well from the first, and often become fairly tame.

They are often chased and killed by dogs, and as a rule make rather a poor fight. During the struggle they utter a throaty cough, and when threatened they give vent to 
a low and rather deep growl. Normally, their cry is a series of low-pitched coughs.

The nursery of young civets is an old ant-bear or other hole in the ground.

Genets. These animals are spread more or less all over Africa. They are smaller animals than civets, but possess the same elongated heads and short legs. The bodies are slender and weasel-like in form. The claws have a certain retractile power, especially in those species which spend much of their time in trees; but they are never so fully retractile as the claws of the cats.

In the Transvaal Game Reserve there exist two very well-defined species, distinct both in appearance and habit.

(I) The Rusty-Spotted Genet. The general colour of this species is greyish white. The stripe along the centre of the back and the rather large spots on the body are uniform red, the latter with a dark outer ring. Weight, about five pounds. Total length, about forty inches.

This genet frequents the neighbourhood of permanent water, and, though it climbs trees, is apparently to a large extent a ground animal. It is solitary by nature, and usually has its day lair in holes in the ground, reeds, long grass, and the thick undergrowth of river banks and ravines.

Its prey consists of rats, mice, locusts, beetles, and birds, especially those of the latter which roost on the ground, or in bushes by the waterside.

The skins of rusty-spotted genets used to be in great demand among the natives of south-east Africa for purposes of clothing and adornment, and are still considerably prized. Though widely distributed in the eastern Transvaal, this species is not nearly so numerous as the following one. 
(2) The Small-Spotted Genet. "General colour pale sandy, lighter than cream. Stripe along the centre of the back jet black, and strongly marked, extending from the neck to the base of the tail. Spots tawny, becoming darker on the flanks, small, numerous, and in five or six rows. Head nearly grey, lighter than the body. General colour of forearm brownish black. Upper surface yellower then the back part, and speckled with small dark spots. Hind limbs below knee black. Tail covered with long coarse hair, and with about ten rings."*

This animal is much the most numerous of all the smaller carnivora present in the eastern Transvaal low country. It is arboreal in habit, and when pursued by dogs, almost invariably takes to a tree, though on the approach of the hunter it generally leaps to the ground and attempts to make off. At such times it sometimes accomplishes bounds of remarkable length. I remember a genet leaping from a height of fifteen feet and landing on the ground twenty-one feet from the base of the tree, a big jump for an animal with a body less than two feet long. Its pace on the ground is not very great, nor does it make a particularly good fight against a dog; any plucky fox terrier can, in fact, kill one without difficulty.

The Small-Spotted Genet is found in forested country, often at a considerable distance from water. It is solitary and quite nocturnal by habit, spending the day in cavities of trees, or stretched at full length along a branch; sometimes, though less frequently, it is found sleeping in clumps of long grass, or in patches of thick bush. Hollow trunks seem often to be used as permanent quarters by the same individual. Any hole or cavity in a rotten trunk in the forest is worth examining for signs of

\footnotetext{
* Thomas and Schwann.
} 
the presence of a genet, and the best way to bolt it is by smoking it out, when it emerges at the last with a grand spring or rush. When angry this genet erects the crest along its back, and spits, snarls, and growls very much like a domestic cat.

It is strictly carnivorous, preying on small birds, guinea-fowls, francolins, and other winged game, besides squirrels, rats, mice, hares, and such lesser mammals, insects, lizards, and possibly snakes. It is also one of the most dangerous foes of the poultry keeper, being both daring and cunning. Its usual method is to take a single fowl at a time, returning for another as soon as it has finished the first, and so on until it has emptied the roost ; but at times a murderous fit appears to seize it, and it will then kill the whole number present, apparently from sheer love of slaughter. In eating a bird, the throat is first seized and the blood sucked; the upper part of the breast is next eaten, and afterwards the thighs and hinder parts. It is also partial to carrion, will come readily to baited traps, and sometimes is caught in the large gins set at "kills" for hyænas and leopards. This species tames very readily when caught young, and even animals full grown when captured tend to lose their fear of man after a time if they are patiently and kindly treated.

Mungooses. These are long-tailed animals, with elongated, slender bodies, short legs and very short wide ears. They are plantigrade, that is, they walk on the soles of their feet, but some species use more of the hind sole in walking than others. The claws are non-retractile, and none of the species is arboreal in habit. In size they vary considerably, from the large grey mungoose, with a body of over two feet in length, down to the little brown mungoose, with his measurement of about nine inches. Their natural food consists of other animals or of insects. 
Some of the varieties tame readily and are most useful in freeing a house from such pests as rats, snakes, and cockroaches, but are most difficult to keep with dogs, which are apt to regard them in the light of natural prey.

Many different kinds of mungooses are recognized in South Africa; but in the wilder parts of the country it is seldom that resident Europeans can be induced to take any interest in the smaller mammals which are not included under the magic name of "game." Mungooses are among the deadliest enemies of snakes, which they attack, kill, and devour whenever they can.

The Large Grey Mungoose. Colour grizzled grey, limbs darker, a black brush at the end of the tail. Length over all about forty-five inches.

This animal is spread throughout the Ethiopian region. It is solitary and nocturnal in habit, and is carnivorous, preying on small rodents, game birds, frogs, and reptiles. In the eastern Transvaal it is usually an inhabitant of the less thickly forested, flat bush country, and the foothills of the mountains. It favours equally rocky and level ground.

Measurements of a large one killed in the Game Reserve were : head and body, twenty-three inches; tail, twentythree inches; fore-girth, nine inches; hind foot five inches.

The Slender Mungoose. This is a small, slightly built creature, about the size of a stoat. Its colour is grizzled yellowish brown, the tail is almost as long as the head and body and is black at the end.

The Slender Mungoose is distributed throughout the whole of the Ethiopian region. It is found equally in thick bush and in lightly forested country. By day it lies up in holes or in long grass. It is nocturnal and solitary in habit, and of a rather bold and bloodthirsty disposition, having the reputation of attacking hen- 
roosts, besides preying on small birds, rats, mice, and reptiles. It eats carrion, and will come to traps baited with any kind of meat.

The Water Mungoose. As its name implies, this creature prefers the vicinity of permanent water, and has its lair in reeds and grass growing by the banks of swamps and rivers. It takes readily to water and preys when possible on crocodile eggs.

The White-Tailed Mungoose. This is a large mungoose, of a grizzled grey colour. It is easily distinguishable by its long tail being white throughout its greater latter portion. The White-Tailed Mungoose has a wide distribution, being met with throughout the larger portion of Africa. In food, habits and size it much resembles the Large Grey Mungoose, but appears to prefer denser surroundings.

Among other well-known mungooses in South Africa are the Ruddy Mungoose, an inhabitant of dry districts, the Small Grey Mungoose, and the Pale Mungoose. A less well known kind is the Small Brown Mungoose. This little animal measures some fourteen inches only in length, of which five or six inches is taken up by the tail. It is grizzled brown in colour, sociable in habit, prefers a surrounding of rather thick forest not too far from water, and uses as dwellings old white ant mounds.

Its food consists of white ants, snails, locusts, scorpions, centipedes, myriapodes, earthworms, reptiles, and the eggs of ground birds and of snakes. It is believed that individuals combine to attack snakes even of the most deadly species, both when the latter threaten their young and at other times, and that they can generally kill them with impunity. Their method is to run in and bite the reptile from behind, jumping back swiftly to avoid its fangs, and repeating the operation until they 


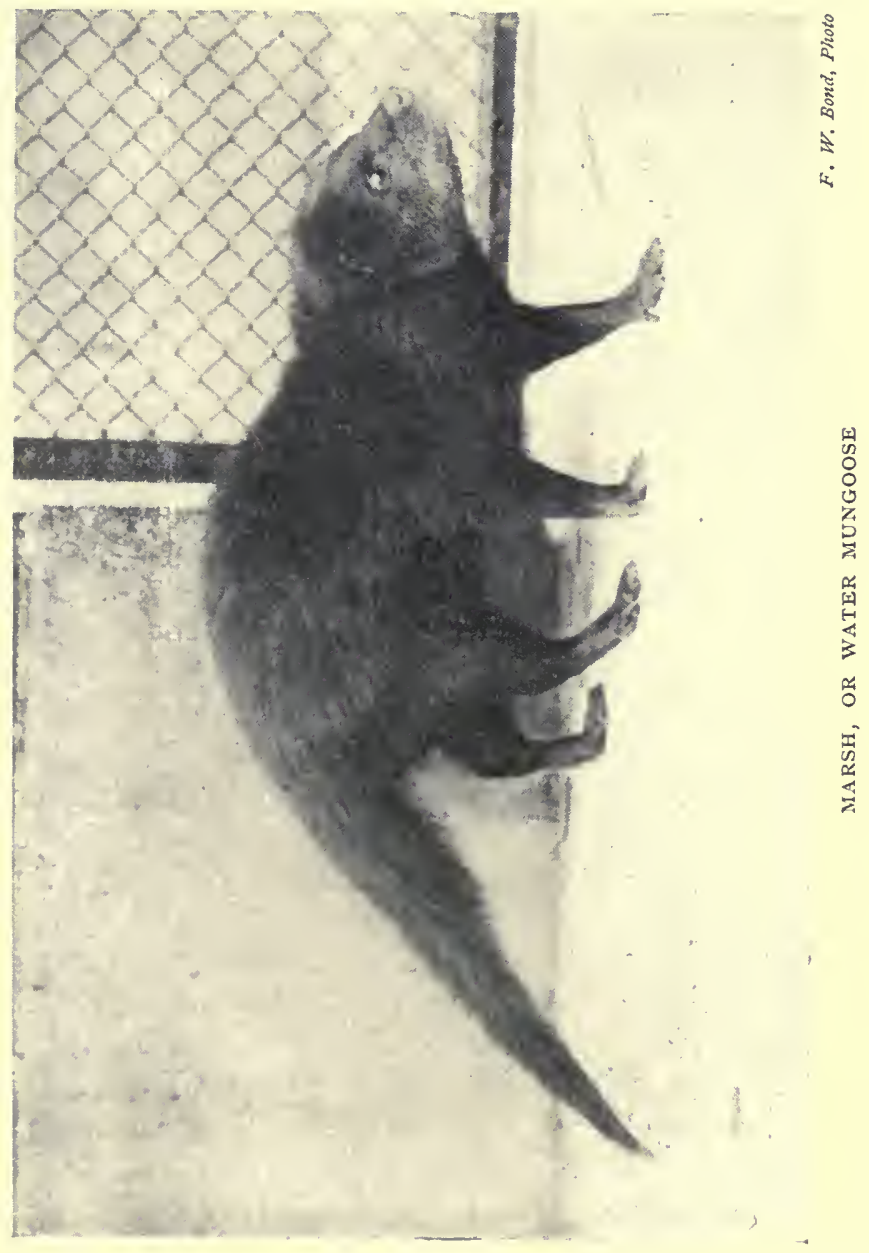


have killed it. The natives assert that when bitten they use some antidote which preserves them from ill effects, but I know of no white man who is able to speak of this matter as being within his own experience. The Small Brown Mungoose is not strictly nocturnal, and several together may often be seen scampering for their burrows at all hours of the day.

Small Brown Mungooses are easily tamed, and make delightful pets, showing a high grade of intelligence, coupled with an intense and boundless curiosity. In addition to their docile traits, these charming little creatures form a valuable ally to man in his struggle against noxious reptiles and insects.

A closely allied species is Wahlberg's Mungoose, the habits of which seem to be very similar to those of the last.

Other small mungooses are Meller's Mungoose and the Banded Mungoose, which is often seen tame on the east coast of Africa, and though larger in size is very similar in habits to the Small Brown Mungoose.

Meercats. This is the term applied to certain genera of mungooses which inhabit the high plateaux of South Africa, where they associate in large colonies. They live in burrows, at the mouths of which they may often be seen sitting on their hindquarters, and gazing inquisitively at passing objects. They are largely day animals, and live on small rodents and birds, insects and eggs, besides killing and eating snakes. Four species are recognized, Selous's Meercat, the Pencilled Meercat, the Bushy- railed Meercat, and the Slender-Tailed Meercat. The last named species, which is very amusing in its habits, and becomes extremely tame, is often kept as a pet in South Africa. 


\section{CHAPTER IX \\ THE AARDWOLF. HYANAS}

THE AARDwOlF. This remarkable animal is in form rather like a hyæna. In general colour it is yellowish grey, with a number of long black and white hairs protruding through the fur. Along the back lies a crest of long hairs which can be erected at will. The body is marked with black transverse, and the shoulders with black horizontal stripes. The ears are narrow and pointed, the legs possess indistinct black bands. The tail is short and bushy with a black tip, and the claws are non-retractile. The length, including the tail, is about three feet, and the shoulder height about twenty inches. The aardwolf is met with throughout the equatorial region, where the surroundings are suitable. It has not been reported from equatorial west Africa and the forest region. In the eastern Transvaal it is not found in the low veld proper, and occurs only in the more open country among the foothills of the Drakensberg, at a height of over I 500 feet. As its name implies, it lives in holes in the ground, and it is nocturnal in habit.

The chief diet of the aardwolf undoubtedly consists of ants, locusts, beetles, and other insects, varied occasionally by carrion, and perhaps eggs. It is not very well supplied with teeth, and its pace is slow. Such natural drawbacks might well be deemed sufficient to exonerate the creature from the accusations of lamb-killing often levelled against it, especially in view of the fact that competent examination of the contents of the stomachs of dead animals has always indicated a purely insectivorous diet, and that ordinary observers are notoriously inaccurate in matters of this kind. The farmers who 
formerly used to trek annually to White River in the eastern Transvaal for winter grazing were, nevertheless, firmly of the opinion that they had absolutely traced the deaths of many of their young lambs to the aardwolf. It seems that, having poisoned the bodies of the dead lambs, they found defunct aardwolves lying beside them next morning. Though this evidence was purely circumstantial, it would perhaps be too much to expect the owners of the stock to believe the animal not guilty under the circumstances. Some say that the aardwolf kills lambs for the sake of the milk found in the stomachs. However this may be, it seems probable that, if he is capable of killing such creatures, he may similarly prey on the young lambs of small antelopes.

\section{HY ENAS}

The hyænas are large, carnivorous mammals, furnished with extremely powerful jaws, strong teeth, and non-retractile claws. The number of cheek teeth on each side of the upper jaw is five, and of the lower four, the corresponding numbers in the cat group being three or four, and three, respectively. The skull has a prominent crest of bone along the middle of the back part of its upper surface, to which, in life, are attached the powerful muscles of the jaw. The tail is relatively short, and the front legs are longer than the hind ones, which gives the animals a very ungainly and clumsy appearance.

The Striped Hyæna. General colour, dirty grey, marked with narrow transverse dark stripes on body and limbs. A mane of upright hair is present on the neck and along the back. In size this is the smallest of the three species. It is common to Asia and Africa, and in the latter continent ranges along the east coast as far 
south as German East Africa. Its habits are similar to those of its relatives.

The BRown Hyena. General colour, ashy brown, with darker bands on the legs and hindquarters. A yellowish white collar is present on the sides of the neck. A mantle of long dark brown hair covers the body, increasing the apparent size of the animal. The tail is short and bushy. Ears large and pointed.

This species, once numerous in South Africa, has now been practically exterminated from the settled districts; but in the north-western portion of Cape Colony, German South-West Africa, parts of Rhodesia, and the northern Transvaal, is still to be met with. It further extends to Angola and German East Africa, and I noticed tracks which seemed to belong to one of the species on the sea shore between Ibo and Port Amelia in Portuguese Nyasaland.

In the north-eastern Transvaal the species is not native to the low bush country, and is everywhere rare. A few specimens have been secured from the kloofs and ravines among the lower hills on the west of the Sabi Reserve, at heights varying from I 400 to 2500 feet. The majority of the natives of the low country to whom I showed the skins had never seen or heard of the animal, and consequently had no name for it; but others, who formerly had lived on the coast north of Delagoa Bay, and along the lower course of the Limpopo River, recognized them at once, and informed me that the Brown Hyæna used to be not uncommon there.

The Strand Wolf, as it is called in South Africa, is a solitary animal, nocturnal in habit, and lying up by day in deep ravines and thick bush. When its haunt is" near the sea shore it is said to live on dead fish, crabs, and other marine creatures. When met with inland it is an eater 
of the same description of carrion as the other species, and also often attacks living animals. On the first occasion when one was caught in the Game Reserve, young goats had been persistently taken from a certain kraal situated amongst the hills, and, the rocky ground showing no tracks, it was believed that a leopard was the marauder. Traps were set, and on the first night a large male Brown Hyæna was secured at the goat kraal, this being, so far as could be ascertained, the first time such an animal had been heard of in the district. A month later a female was caught in a deep ravine near the same place, and at intervals of a year or two a few others were trapped at lower elevations. The old natives who told me they had known the animals in Gazaland said they often took young goats and sheep, and sometimes even small children, from the kraals at night, besides attacking sleeping men and women after the manner of the Spotted Hyæna.

The Spotted Hyæna. This is the biggest of the three species. Its head and forequarters are very large and massive, but it droops and slopes away behind to such an extent that the two ends of the animal seem out of proportion to each other, and its appearance when moving is most ungainly.

The general colour is ochrey yellow, dotted with large circular dark spots. The head is darker than the body, and is unspotted. There is a ruff of long hairs on the neck, which is sometimes very pronounced in adult males. The ears are short, broad, and rounded; tail short with a small tuft at the end. The length of a good male is about seventy inches over all, and the height at the shoulder about two and a half feet. The skins vary a good deal in colour and type, even within the same areas. For instance, a female which was killed on the 


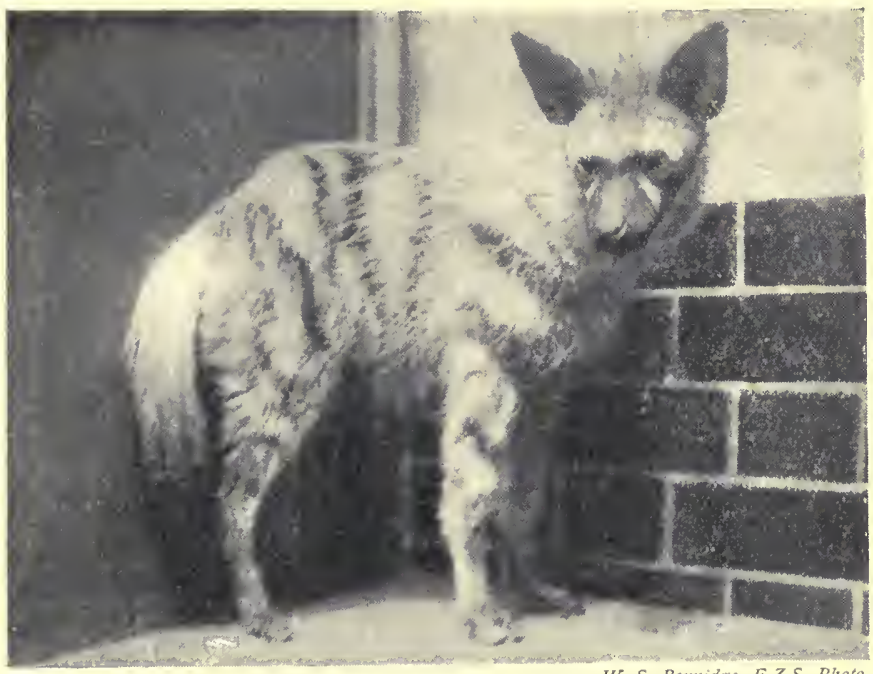

AARDWOLF

W. S. Berridge, F.Z.S. Photo.

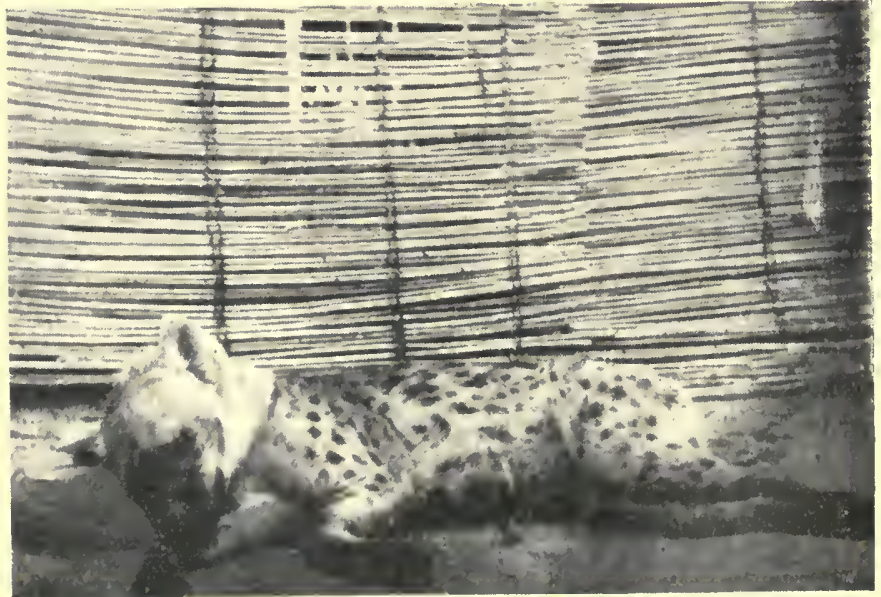

SPOTTED HYENA

(Sabi Game Reserve) 
Sabi River in October was dirty white in colour, while the spots over the whole fore-part of the body were so faint as to be barely distinguishable. On the other hand, in November, two females, apparently mother and daughter, obtained some thirty miles north of the above-mentioned place, possessed skins of reddish grey hue with nearly black spots, the hair on the bodies being rather long. Between these two extremes I have noticed every sort of variation, equally in shade, length of hair, and distinctness of spots. No doubt with age the coat tends to wear away, as immature animals or those in their early prime often carry, in the eastern Transvaal, quite handsome coats, while old males generally look very shabby in this respect.

The Spotted Hyæna, where not exterminated by the advance of civilization, exists throughout most of the African continent, and is found even in districts thickly inhabited by natives, where it lives on the offal and refuse of the villages. Formerly these animals used to swarm round the town of Tete on the Zambezi, and after dark would enter the narrow streets of the native quarter in large numbers, admirably fulfilling the duties of public scavengers, duties which otherwise would have been sadly neglected.

Spotted Hyænas are nocturnal in habit, but may be seen on the move upon cool and cloudy days, and often for some time after sunrise in bright weather; indeed, I have heard them calling quite an hour after that time. They leave their lairs at dusk, and during the night travel by preference along the game tracks and native paths, sometimes patrolling backwards and forwards along one stretch for hours. In the day-time they lie up in thick bush or in long grass, occasionally, especially in mountainous country, sheltering themselves 
in holes and caves. I have come across individuals during the heat of the day lying in forest pools, completely immersed except their heads. They are very heavy sleepers, and it is often possible to approach quite close without disturbing them when thus occupied. When in quest of food they often follow lions and troops of hunting dogs about the country, and snatch every opportunity for a stolen repast. They have wonderfully keen noses, and can detect the slightest taint in the air at a great distance, when their signal cry conveys the information to others still farther away. It is certain also that, especially in cloudy weather, they occasionally make towards any spot above which they have noticed vultures gathering, recognizing in this a tolerably sure indication of the presence of a carcass.

Although a large number of Spotted Hyænas may sometimes be found collected at a "kill," or following in the tracks of some of the larger game-killing animals, it is quite incorrect to assume that they are sociable by habit. They are, in fact, solitary animals, and when a number of individuals are drawn together for a common purpose they separate, and depart singly, or in pairs at most, in different directions as soon as that purpose has been fulfilled. A family party consisting of father, mother, and offspring, a common sight among some kinds of animals, is outside my experience as regards hyænas.

The cubs seem to remain in company with their mothers until about half grown, and I think that in a wild state seldom more than one of each litter arrives at maturity.

Spotted Hyænas live principally upon carrion and bones, the latter being first cracked and then crunched up by the powerful jaws as easily as another animal would dispose of a piece of meat. Not until a tame 
hyæna has been kept and tested, can his capabilities in this direction be properly realized. The largest bones are quickly broken up; small ones are simply chewed and bolted like so much bread. Meat is eaten without regard to whether it is fresh or in the last stage of decay, and every portion of a carcass, including the intestines, is consumed. Hyænas will eat the flesh of any mammal or bird except that of one of their own kind. It is possible that cases of cannibalism occur, but I never came across one, nor remember a hyæna coming to a trap baited with the remains of another. His lack of speed and his natural tendencies prevent him from being a game killer in the same sense as the hunting dog or the leopard, but he has been known to attack cattle and donkeys, while infirm and crippled wild animals and the unprotected young of all species fall ready victims. A fox terrier was seized and carried off from my camp one night by a hyæna.

It seems highly probable that not even the young of the fiercest and largest beasts of prey altogether escape the undesirable attentions of the prowling hyæna. Very young lion and leopard cubs are often left alone for many hours during the night while their mothers are away seeking their prey, and I am personally of the opinion that at such times a considerable number fall victims to this wily robber. A friend of mine once shot a hyæna, which proved to contain in its stomach the claws and part of the skin of a very young leopard, and there seems little reason to doubt the assertions of many old natives who declare that lion cubs, too, sometimes meet the same fate. A serval, caught in a trap, was found to have been eaten out of it by a hyæna, just as a captive mouse is sometimes treated by a cat. More remarkable still was an incident which occurred in June I908, when 
Ranger Duke, visiting one of his large traps in the morning, found, fixed in the jaws, the foot and part of the leg of a half-grown leopard. It was abundantly clear, from the bush signs, that this animal had been killed, dragged out of the trap, and eaten by several hyænas.

Skins, raw-hide ropes, anything with the slightest smell of animal matter about it, is liable to be taken from the camp at night by these creatures if not securely put away. I have known unopened tins of corned beef broken up in order to get at the contents. One night at Sabi Bridge, long ago, a hyæna entered the veranda of the blockhouse, then used as a living room, and, upsetting all the furniture, departed with a large bundle of more or less cured skins which were hanging on the wall. He had to climb up a flight of twelve steps to reach the place, and natives and dogs were sleeping close by. Another night I was aroused by the latter barking, and, running out of my hut, found a large hyæna standing in the bright moonlight in the act of trying to pull up a leopard skin pegged down just outside the door.

Before the Game Reserve was established, and while the war was in progress, Sabi Bridge had been the headquarters of a section of an irregular corps, and there being a great deal of camp refuse to dispose of, and a large number of horses continually dying of horsesickness, hyænas got into the habit of collecting from far and wide. As, under the circumstances, they did a great deal of good, they were very properly left alone. Consequently, in the early days of the Game Reserve the compound used to be a resort for a great many of these animals between darkness and dawn, the nights resounded with weird sounds, and all sorts of property, including small domestic animals, were continually disappearing. It therefore became imperative to reduce 
their numbers, and it was not before about twenty had been trapped and shot that the nuisance began to abate.

There is no doubt that when a man has to sleep out in the open, the Spotted Hyæna must be reckoned a very dangerous beast. Mr. R. T. Coryndon told me that once, many years ago, he and a friend found themselves obliged to spend the night fireless and tentless in an old mealie field. Mr. Coryndon was sleeping on his back, his hand behind his head, when he was suddenly seized by the wrist and dragged right out of his blankets. He shouted at the top of his voice, and the animal let go, when he found that his wrist was rather badly bitten. Having, with the assistance of his friend, dressed and tied it up, he once more lay down, this time taking the precaution to have his loaded rifle in readiness. At the end of half an hour he saw something suddenly loom up against the sky-line just in front of his feet, and immediately firing, killed a large hyæna, which was doubtless on the point of resuming the attack.

There are many instances on record of sleeping natives having had pieces torn from their faces and other parts of their bodies, whilst sleeping round the fires at night, and I have seen men in widely separated parts of Africa who have suffered dreadful injuries in this manner.

When sitting up at night over "kills," there often occur many interesting opportunities of observing the methods of Spotted Hyænas. Soon after dark a longdrawn howl will be heard coming from somewhere far away in the forest. It is answered from another point, and presently the chorus is taken up from all directions, As the night draws on the cries approach closer, until at last one issues from the bush close at hand. Then follows for a time silence, but the lonely watcher can detect faint rustlings and undefined sounds in the dark covert 
surrounding the open space in which the "kill" lies. Now a stealthy shape shows itself for an instant on the edge of the bush, darting back again immediately to shelter. Now a maniacal shriek, one of the most creepy sounds to be heard in the African bush, smites the ear, to be succeeded by another interval of dead silence.

At last, without warning, there is a rush, and a dark form dashes in at the carcass, and, seizing it, attempts to drag away the whole or a portion. A hyæna bolder than the others has at last become convinced that all is well. If lashed firmly down, as it should be, the "kill " will probably hold fast; but a mouthful of intestines, or a large piece of flesh, may be the reward of the robber, who is at once lost to sight in the outer darkness, whence arises a babel of the most extraordinary noises-weird chucklings, screams of eerie laughter, and, occasionally, the typical cry of the hyæna. Several further isolated rushes may be made, and then, if the watcher does not betray his presence, the animals will most likely close in boldly upon the bait. As a gunshot is heard very far at night, and may disturb nobler game, now perhaps drawing near, it is well on such occasions to be provided with a good supply of stones, which serve to scare away the scavengers without unnecessary noise.

I once watched a hyæna manœuvring under a branch, whereon had been placed some freshly killed meat. There was a pretty good moon, and the animal could be clearly seen running backwards and forwards at a springy trot, now gazing up at the tempting morsels, now eagerly snatching up some trifling scrap of meat from the ground. Occasionally he seemed to dissolve into the shadows of the background, to dash out and rear himself against the trunk as if to climb the tree; then he would take a succession of springs, some of them of surprising height, 
straight up at the meat. During these operations he maintained complete silence.

In view of the alertness and sagacity displayed by the hyæna in the not always easy task of seeking his daily bread, as well as the extraordinary mixture of caution and boldness which he often displays, it is no wonder that the leopard is driven to place the remains of his meal in the safety of a tree when temporary absence becomes necessary. That even this stratagem may occasionally fail where due care has not been exercised, the following incident tends to indicate.

As read by the bush signs on the morning following a heavy storm of rain, what occurred was as follows: A leopard had hauled a portion of an impala up a tree, and, as usual, had laid it in the fork formed by one of the branches with the trunk, at a safe distance from the ground. $\mathrm{He}$ had then descended and gone to the river, a mile or so away. Seizing the opportunity, a watchful hyæna, which doubtless had been hungrily eyeing him at his meal, came to the foot of the tree and gazed longingly at the delicacies there stowed beyond his reach. Now although the height at which the meat had been placed was prohibitive, the tree itself was too small and light for its purpose, while the branches above, being of inconsiderable size, must not only have retained the carcass with difficulty, but swayed dangerously with each gust of wind. The hyæna had run round and round, leaping against the trunk, and at last, either in baffled rage or with surprising astuteness, had commenced to gnaw through it. The powerful jaws had bitten out and torn away a great deal of the wood, when either the shaking below, or some more than usually severe blast above, or both combined, had at last detached the meat from its position, so that it fell to the ground, to be immediately 
seized and dragged off. Unluckily for the thief, the leopard must have returned just as this happened, and the spot where the robber had hastily dropped his booty and the rightful owner recovered it, was easily discernible some twenty yards away. Having regained possession, the leopard had proceeded to place the "kill" securely in a large tree, where we found it in the morning.

Although, considering their size, strength and natural powers, Spotted Hyænas are cowardly animals, they display at times partially redeeming qualities. It is not uncommon for individuals to rush in at the carcass of an animal killed by a lion, in order to snatch a mouthful, even when the king of the forest is still enjoying his meal-a piece of daring often paid for with life. I have seen wounded hyænas defend themselves well when mobbed by dogs, and remember having one of the latter killed in this way. The hyæna gripped his neck for the fraction of a second, and although there was little external mark and the skin was not broken, the dog died in a few minutes, the powerful jaws having crushed the internal organs in a terrible manner. On the other hand, a large animal, chased and held by a half-bred greyhound and a boarhound, showed very little fight. A case somewhat similar to that related by Mr. Selous, of a hyæna being attacked by and defending himself against a pack of hunting dogs, was noticed a few years ago in the Transvaal Game Reserve. On this occasion, though putting up a good fight, his back against a tree, the hyæna, badly injured and much exhausted, no doubt would shortly have been killed. When a single domestic dog chases a hyæna, the latter, after decamping for some distance, will not infrequently turn round upon his pursuer, unless the latter happens to be exceptionally big and powerful. 
The voice of the Spotted Hyæna is one of its most remarkable qualities, and there are few wild animals capable of uttering such a variety of sounds or of imparting so many inflexions of tone to each. The usual note is the well-known and long-drawn "whoo-oo," the first syllable pitched in a deep bass key, while the second rises to a shrill falsetto scream. It is round a carcass that the hideous maniacal laugh, whence the animal derives one of its titles, is usually uttered; but I have also heard it when hyænas are prowling round a camp and have smelt meat. Occasionally a deep "wuff " is given vent to, and when tackled by dogs or wounded they sometimes growl.

The above, however, by no means complete the catalogue of sounds of which this creature is capable. I was fishing in the Sabi one evening, a few hundred yards outside the compound fence, and the shadows had already gathered, before, having taken my rod to pieces, I began to retrace my steps. Just as I was leaving the bank, a most extraordinary series of sounds came from the recesses of the bush fifty yards away. There was a shriek as of some human being in distress, followed by a number of low gurglings and chucklings, and then by another shriek. Knowing that no natives were in the bush, I stood wondering what it could be, and as I listened to the noise several of my native servants, with assagais and lights, came running at top speed through the compound gate. They at once said, in tones of relief, "We thought some one had been taken by a lion." The sounds still went on, now recalling the wails of an infant, when suddenly the familiar "whoo-oo" set all doubts at rest as to the nature of the animal. $*$

Hyænas come freely to baits, and are constantly caught in traps and shot by spring-guns. They show 
great audacity, and I have often known one lightly caught drag away the bait after releasing himself. Sometimes, too, they will step over the carcass of a leopard already killed by a spring-gun set over his "kill" in order to get at the latter. So powerful are the hyæna's jaws that the tongue of an iron trap is often bitten out, or so badly twisted as to render the implement unserviceable for the future.

Although hyænas must be considered noxious vermin on account of the damage they inflict upon stock, game, and occasionally human beings, it cannot be denied that they fulfil very useful purposes as scavengers ; they will eat any kind of offal, and share with the vultures the credit of keeping the bush free from many distressing odours.

If caught young these animals become very tame. We kept one at Sabi Bridge which knew its name perfectly well, and displayed considerable docility and affection. In fact, when I visited it at the Pretoria Zoological Gardens some weeks after its arrival there, it recognized me at once, and executed a series of clumsy gambols round its cage on hearing itself called by name.

\section{CHAPTER X \\ JACKALS AND FOXES}

THE next group of carnivorous animals includes the dogs, wolves, jackals, and foxes. The members of it possess elongated muzzles, a large number of cheek teeth, limbs built for speed, and non-retractile claws. All are gifted with high intelligence, of which the capacity for combination shown by some species is one of the most obvious outward signs. 
The Black-Backed Jackal. This animal is slightly larger than an English fox, and is much the most handsomely coloured member of the genus. The back is black, interspersed with white hairs; the sides of the body and limbs are rufous, and become paler on the underneath parts. The ears are comparatively large, and the muzzle sharply pointed; the tail is bushy, with a black extremity, a few white hairs being sometimes present at the tip. Individuals, however, tend to vary even when of similar sex, and at the same time of year; grey hairs occasionally predominate over black ones on the back, the rufous colour of the sides varies in tone, and the definition between the tints of the back and sides is not constantly sharp in all specimens.

The Black-Backed Jackal ranges through the equatorial region from Abyssinia to Cape Colony, wherever the surroundings are suitable. It prefers open, or lightly forested country, and by day lies up in thickets or long grass. When hunted by dogs it will sometimes go to earth, and the young are born underground. It is an extremely alert and cunning little animal, possessing a high turn of speed, as well as a considerable amount of daring. In habit it is rather solitary, though, like all scavenging species, individuals are prone to collect where carrion lies. Mating pairs are often seen together, as well as females with one or more well-grown whelps. Where not much disturbed, the animal goes about a good deal by day. Its senses are very acute, and when alarmed it moves away at a light, springy gallop.

The cry of the Black-Backed Jackal is a shrill "Yaaaya-ya-ya-ya," repeated quickly several times.

Besides eating carrion, eggs, locusts and other insects, and reptiles, it preys upon all wild birds it can catch, especially ground francolins and guinea-fowls, while it is 


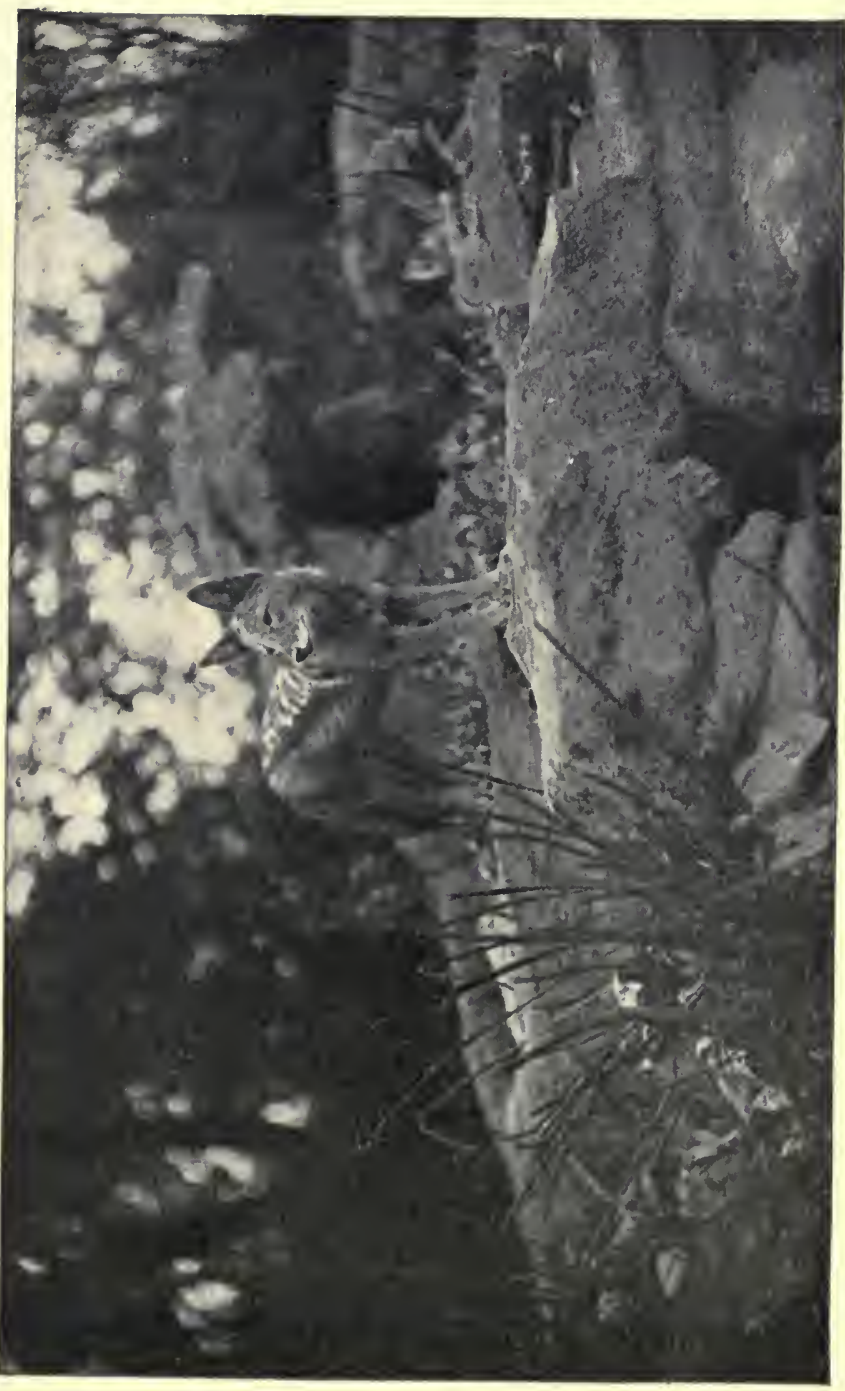

告 
a dire foe to the poultry farmer. Among mammals practically all that can be overcome are devoured-rats and mice, small mungooses, hares, and the young and even half-grown of the smaller antelopes up to the size of duikers. The latter are often run down in fair chase, for this animal can move with great speed, and rangers have recorded having witnessed such hunts upon more than one occasion. It does great damage to sheep farmers by killing lambs, and, principally on that account, a war of extermination has been waged upon it through many parts of South Africa. I have seen these jackals eating pythons, and it is quite possible that the native testimony as to their occasionally killing these reptiles is quite correct.

It is said that when he finds a python asleep in the grass, especially when helpless after a heavy gorge, the jackal watches his opportunity, and, springing in, seizes it by the head. If the snake is a very large one, he inflicts one severe bite, and instantly leaps back out of reach, awaiting another chance; but where a small individual has to be dealt with, he maintains his hold, and rushes off dragging it along at full speed, so that it may be unable to secure a purchase with its tail. Should it succeed in doing so he lets go at once and springs out of harm's way. On the other hand, a python in ambush, and on the look out for prey, will catch and swallow a Black-Backed Jackal as readily as it will any other animal of the same size.

The Side-Striped Jackal. This is a rather larger and stouter built animal than the last, but lacks its alert appearance and active ways. The usual colour is silvery grey, with a brownish tinge; a white and a black stripe run horizontally on either side of the body; the face and limbs are rufous, and the tail has a white extremity. 
The muzzle is less slender than that of the other kind. Skins vary much in colour, and out of a series of twenty or thirty it is seldom that two are marked exactly alike. They rank through all shades of grey, from pure silver to very dark, and sometimes are almost wholly russet brown. The stripes, too, vary in intensity, in some specimens being very clearly marked, while in others they are very indistinct.

The range of this jackal extends from five or six degrees north of the Equator to as far south as Zululand. . In the eastern Transvaal it favours rather more thickly wooded country than the other species. It is sometimes found in the dense thorn bush of the Sabi ; while just outside that belt, where the forest is sufficiently open to admit of a horseman moving with comfort at a slow pace, it is very numerous indeed.

By nature the Side-Striped is much more sluggish than the Black-Backed Jackal, and is also more nocturnal and solitary in habit. By day individuals lie up in bush, issuing forth at night to seek carrion, or to prey on small mammals and ground-roosting birds. It is a dangerous poultry thief. One used to lie in wait regularly, just outside our compound fence, in order to catch such fowls as wandered far afield in the early mornings. It was only after a considerable number had thus disappeared that the culprit was discovered, and dealt with.

The species is, however, not entirely carnivorous, and, in addition to locusts and other insects, will eat certain wild fruits. I do not think it ever attacks mammals of larger size than a hare, and it relies on catching its prey by pouncing on it, and not by running it down, its speed being comparatively slow. It seems, moreover, relatively a little deficient either in power of sight or hearing, as, when the wind blows favourably, it is often 
possible to approach individuals unnoticed within a distance which would be almost impossible were the BlackBacked Jackal in question. Constitutionally it is rather timid, and generally makes a poor fight against dogs. When attacked by the latter it sometimes seeks to escape by shamming dead. I remember that one animal, after being worried by a dog, lay quite limp on the ground for a few moments and then suddenly sprang up and made off. Upon being again caught, it repeated the trick; but as soon as the dog dropped it, instead of running away, it sprang at his throat. It received a third shaking, and was again quiescent during the process, but rushed a second time at the dog immediately after release. I think the pluck of this animal was very exceptional for one of its species.

Side-Striped Jackals go to ground readily, in old antbear or other large holes.

They become quite tame if caught young, and even full-grown animals, though inclined to show their teeth, soon eat and drink regularly, and, after a time, resign themselves to the new life.

The call of the species is a single cry midway between a howl and a bark.

Other recognized species of African jackals are :

The Egyptian Jackal, the largest of the group.

The Morocco Jackal.

The Variegated Jackal, from Abyssinia and Somaliland.

The Pigmy Jackal, from Somaliland.

The Silver Fox. With this species we come to the fennecs, or African foxes, which are of slighter build than the jackals, and possess more sharply pointed muzzles, and longer and more bushy tails. The general colour of this fox is silvery grey, the underneath parts 


\section{THE AFRICAN HUNTING DOG}

being tawny in hue. The fur is very soft and thick. The tail is long and bushy, the hairs of mingled yellow and black, and the tip of the latter colour. The ears are long and pointed.

This fennec is peculiar to South Africa, and is there found from the newly acquired German territory across the Cape of Good Hope Province and the Orange Free State, to Natal. It favours high upland country, and does not appear ever to have been very common.

Its diet consists of insects and wild fruits.

Two other African species are known.

Delal ANDE'S Fox. In colour and shape rather like the Silver Fox, this kind is distinguished by the greater number of back teeth, and by its somewhat longer ears. There is a dark streak running through the eyes and down the centre of the nose, and the toes are black.

This fox is found chiefly in the western and drier parts of South Africa, and has also been found in East Africa and Somaliland.

It affects dry uplands, and its food consists of mice, insects, fruit, and perhaps small birds.

The Cuberow. Though known as the Abyssinian wolf, this animal is really more akin by nature to the fox. It is local and rare, and has been seen principally among the Simien mountains.

\section{CHAPTER XI}

THE AFRICAN HUNTING DOG

IN South Africa, as in other places, many species of animals have received names, not only in no way suited to them, but sometimes actually the property of entirely different animals existing in other parts of 
the world; while it not uncommonly occurs that the name given to a certain type might be not inaptly applied to another inhabiting the same locality. Thus a leopard is called a "tiger," a giraffe is known as a "camel," and a hyæna as a "wolf," while the present species, whereto the latter term would, perhaps, be more appropriate, is a "dog." The name "dog," in fact, is not at all descriptive of this animal ; for there are few other members of the family differing more widely from the true dog, and he is a remoter relative to the latter than either the wolf or the jackal. The animal is, indeed, the sole living survivor of its type, and differs from all the members of the dog group in having only four toes to each forefoot.

In appearance the Hunting Dog is large and powerful, standing between two feet and two feet and a half at the shoulder, a male weighing about sixty pounds. His muzzle is relatively short and broad, while the great upstanding round ears are among his most striking characteristics. The body and limbs are marked in patches of black, white, and dull yellow; the tail is bushy, usually with a white tip, and there is a moderate throat ruff. The animal possesses a curious outer skin, which contains the roots of the hairs, and which is very easily separated from the thicker layer of skin beneath; consequently unless a specimen is skinned very soon after death, this outer envelope quickly shrivels, and peels off in the sun, thus spoiling the trophy. Although the limbs are long and powerful, and the forehand massive, nevertheless the animal falls away behind; a circumstance which, taken in conjunction with its habit of carrying the head and tail depressed when moving at its ease, gives it rather a hyæna-like appearance, and is responsible for the term "hyæna dog" formerly applied to it. In no other point either of structure, disposition, or habit, 
however, has it the remotest resemblance to that professional scavenger. It has a very strong and distinctive odour, and, under certain atmospheric conditions, the proximity of a pack is quite obvious even to the human nose.

Naturalists have divided the Hunting Dog into several local races, and it seems probable that the tendency of the species is to become larger in size and lighter in colour the farther it ranges south. The types found in Somaliland and British East Africa are relatively small in size, and the black in the coat strongly predominates, while the extreme southern representatives from Cape Colony, besides being much bigger animals, have ochre or buff as their main colour, and comparatively little black present. Between the two extremes are all kinds of variations. In Hunting Dogs of the north-east Transvaal, southern Rhodesia, and the neighbouring province of Moçambique, the three colours are, on the whole, evenly distributed, in some specimens one hue predominating, in others another. There is no doubt, however, that the males generally are very much darker than the females and immature animals; some of the former, especially old ones, having hardly any white upon them at all, and the yellow of a dark and dull shade; while among the latter, many-though not all-individuals are brilliantly marked in big splashes of yellow, white, and black. During the winter season, too, the coats of both sexes are longer and duller than in summer.

The range of the Hunting Dog comprises the greater part of Africa from the Sudan to the Cape, and no doubt extends to some regions whence its existence has not yet been reported. Notwithstanding its wide distribution, it is an animal comparatively seldom encountered by the sportsman, a fact largely accounted 
for by its restless habits and the vast areas over which it unceasingly roams. It is met with alike in open and in bush country, wherever game exists, water is to be had, and the forest is not so dense as to impede its pursuit of prey. It is sociable, associating in bands, the size of which is largely dependent upon the food-supply of the district. The pack which hunts the country between the Sabi and Crocodile Rivers in the Transvaal Game Reserve, and which ranges over an area of some $I_{500}$ square miles, well stocked with impala and reedbuck, consisted, before it had been artificially reduced in numbers, of between sixty and seventy individuals. A second pack, having a very wide range, from the Sabi on the south to the Olifants River on the north, and from the foothills of the Drakensberg on the west, nearly to the Limpopo River on the east, was never quite so numerous, in spite of the wider area at its disposal. In early South African days Gordon-Cumming and others have recorded bands of several hundreds, and, in view of the enormous numbers of the herbivorous animals then existing, there was probably nothing unusual in such a sight.

Hunting Dogs mainly hunt between the first streak of dawn and the first hour after sunrise, and again from about an hour before sunset until dark. When the moon is good, however, they often pursue the chase far into the night, and once, under a full moon, they pulled down a half-grown male waterbuck close to my camp at Tshokwana about I2.30 A.M. At other times their rallying cries have been heard as late as Io P.M., while I have known them hunt all day in cloudy and cool weather. Normally, however, the morning hunt ceases soon after sunrise; the scattered units, mutually guided by the assembly call, join up, and, after a short rest, proceed 
in leisurely manner towards the nearest water, being continually joined on the way by stragglers from all directions. In drinking, deep pools and large rivers, are, as far as possible, carefully avoided, no doubt from a lively fear of crocodiles, and shallows near the main streams, or small pans in the otherwise dry sand-spruits are preferably chosen.

Having satisfied their thirst, the pack next seek some sandy stretch-the bed of a dry watercourse or river bank-where, if the hour is still early, and the sun not too hot, the members will roll and bask, while truants keep dropping in. Later, as the day gets warm, repair is had to the shade of a tree, to a cool clump of reeds, or to a patch of undergrowth, where sleep is indulged in during the hot hours. As the shadows begin to lengthen, and the air cools, the time approaches for another visit to the water, immediately after which comes the evening hunt. This over, they may drink again should there be sufficient light; but, generally speaking, I do not think Hunting Dogs care about moving through the bush on dark nights, and at such times the pack usually rests, huddled up together for warmth and mutual protection. When returning to camp late one night I came on a number apparently sleeping, in the midst of a dense thicket, and no doubt this is a general practice.

There is no other beast of prey in Africa responsible for so much disturbance of game as the Hunting Dog, and, in proportion to his numbers, there is none which deals out more wholesale destruction. A pack, descending suddenly upon a district, scatters the game far and wide, and it is not difficult to discern from the restless and uneasy manner of the impala and other antelopes, as well as from the fact of the herds being split up and scattered into small parties, that these bush pirates are 
on the war-path. The disturbance which their presence causes being so intense, the area quickly ceases to supply them with food, and they are consequently obliged to move on elsewhere; the frightened game, when assured of their departure, closing in once more behind them. It follows, therefore, that the range of each pack must be a wide one, and the life of every individual composing it so necessarily strenuous that none but the very fittest can survive. Nature thus provides that the increase of these destructive creatures shall not be unduly large, and, from this and other reasons to be mentioned presently, the numbers present over any given area of country are generally less than those of some of the other species of greater carnivora. From the fact that they are seen associated in large troops, and may appear in two widely separated localities within a surprisingly short space of time, they are often believed, however, to be far more numerous than is actually the case.

In order to arrive at some estimate of the movements and total of the Hunting Dogs in the Reserve, notes, extending over some years, have been made by rangers whenever a pack has appeared in their several districts. A comparison of these shows that within the area between the Sabi and Crocodile Rivers on the north and south, and the Drakensberg Mountains and the Lebombo Hills on the west and east, Hunting Dogs have never been reported present in more than one ranger's district at the same time. Successive reports indicate that they have reappeared after fairly regular intervals in each district, remained for some days, or weeks within it, and then have been temporarily lost sight of, to be shortly reported from the neighbouring area.

At Sabi Bridge, some nine years' observation of their habits has shown that they nearly always have approached 
from the same direction, namely from the west, have hunted down the Mutshidaka Spruit to the Sabi, and then, in the dry season, along that river for some forty miles to the Lebombo, whence they have turned south towards the Crocodile. In the summer they cross the Selati Railway, and work the series of small tributaries which run into the Sabi from the south; eventually reaching the Crocodile system, and so back towards the west.

I speak, of course, of the movements of the main body ; but so far does the chase sometimes lead, that individuals and small parties may be separated from the majority of the pack for many days and even weeks, and therefore may be encountered in all sorts of unexpected places. I remember, while the bulk of the southern pack was near Sabi Bridge, four stragglers ran into and killed a duiker by my camp twelve miles up the Sabi. The movements of the troop north of that river are more difficult to follow, both because the area is much larger and because the animals disappear into Portuguese territory, sometimes for months at a stretch ; but records have been kept as far as possible, and, so far as they go, they show a fairly regular method of progression. Naturally, as game increases, so Hunting Dogs, unless artificially kept down, will tend to become more numerous, and small detached parties, finding themselves in a wellstocked country, may become the nucleus of a fresh pack. Of this there was an example just north of the Sabi, where a small troop from the northern pack, broken off in the course of some long hunt, more or less took possession for some time of an area of thirty or forty miles of country.

Few wild beasts display more sagacity in pursuit of prey than this one. Watch a pack in the grey morning 
light as they quarter the bush in quest of some unsuspecting herd. They ramble along at hounds' pace, each individual with head and tail held low, and in perfect silence; a silence which, by the way, is never broken throughout the whole course of the hunt. On coming on a fresh "line" there is no increase of pace, but the leaders prick their great round ears and jump at intervals straight up and down to get a view over the top of the grass and low scrub. Now some impala can be seen down an aisle of the bush calmly browsing, and immediately the whole pack spreads out noiselessly, in order as far as possible to encircle it. A ewe raising her head quickly, in an interval of feeding, catches sight of one of the sinister forms stealing from bush to bush; she snorts loudly, and, in a moment, as by one impulse, the pack dashes in.

Away in all directions, and in the extremity of terror, dash the antelopes, springing high into the air, and, in the confusion, often impeding one another in their frantic efforts to escape. One or two are instantly seized and pulled down, and the rest of the pursuers, splitting up into small detachments, relentlessly pursue the unfortunate individuals which they have singled out. There is seldom any escape; gifted with marvellous speed for a short distance, and with immense endurance where the chase is long, the Hunting Dog is served when occasion demands as well by his powers of scent as by his muscular limbs, and fortunate indeed is the creature, which, once having formed his quarry, can safely win out.

The actual method of chase has often been described. The pack lopes along some yards behind the intended victim, each individual in turn spurting up alongside to spring at the flank or quarter, tear away a mouthful of flesh, and then drop back level with his companions. 
Soon exhaustion and loss of blood tell their tale, and the hunted animal falls to the ground, when the pursuers rush on it like hounds into a fox, tearing it to pieces and devouring it in an incredibly short space of time. It is a ferocious method of hunting, and the state of the quarry when at length pulled down is often pitiable in the extreme. Two Hunting Dogs once ran into an impala ewe close to one of my camps on the Sabi. They were at once driven off by the natives, and the ewe was still alive, and trying to rise, when I came up. She was in an appalling condition: both her flanks torn open, and the flesh of one quarter stripped entirely off from the base of the tail to the point of the hock, so that the bone showed throughout.

During the lambing time of the impala and reedbuck, the young of these species seem to form the principal prey of Hunting Dogs, and the number of lambs destroyed is enormous. I remember following a pack of about thirty, which for two days, about the end of November, had been playing havoc among the young impala near Sabi Bridge. I counted at least a dozen kills within a radius of less than a mile-all those of small lambs. An impala of about a week old forming one meal for a single dog, and there being but little difficulty in running it down, the harm that is done to the increase of the herds in this way may easily be realized. I crept up to three dogs which were busily employed in eating a young buck, and was struck by the frenzied haste which they showed in rending it in pieces and bolting the flesh in huge lumps.

One instance will serve to indicate the rapidity with which these animals dispose of their food. Two native police, stationed at one of our pickets, heard a duiker cry out close by. Pausing only to seize their spears 
from the hut, they ran to the spot, hoping, of course, to secure some meat for themselves; but, although between the time of the first alarm and their reaching the place barely three minutes could have elapsed, nothing remained on the ground except a little blood and some pieces of skin, while three or four Hunting Dogs could be seen decamping through the bush.

One of the reasons why the wild dog is so terrible a foe to game lies in his wasteful method of hunting. For example, two or three individuals, having pulled down an impala or reedbuck, will eat as much as they can conveniently stow away, and then, leaving the carcass just where it happens to lie, will leisurely proceed to rejoin the rest of the pack. The remainder of the meat is abandoned to the vultures, and on the following day a fresh victim is pursued and slain. Unlike the felines and viverrines, Hunting Dogs take no precautions to preserve their food against the professional scavengers of the forest, having no intention of returning for a second meal. They live entirely upon animals which they have killed themselves, and very rarely touch carrion. We have seldom caught them in traps, and most of those so taken were either old, and so unable to keep up with the pack, or injured in some way. I once shot a female in the act of feeding on an abandoned leopard kill; but on examining her I found that a bullet wound in the quarter, inflicted apparently about a month before, had rendered her incapable of hunting.

This contempt for any but fresh meat renders Hunting Dogs more than usually difficult animals to deal with. Traps and poison seldom avail against them, at least in districts well stocked with game; for where food can be easily secured, and where consequently there is no necessity to return to kills, the area in which a pack is 
found to-day is precisely that wherein it is unlikely to be met with to-morrow. The rifle must therefore generally be the most useful agent in keeping down their numbers. If the breeding holes of a pack can be found it may then be possible to poison or trap a good many of the females, and capture the whelps; but unless steps are

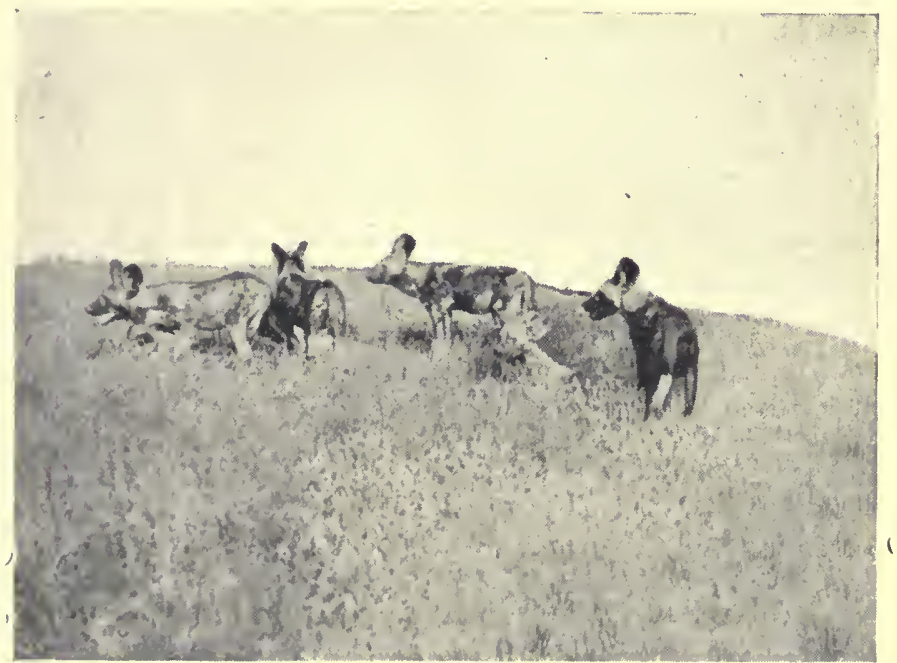

AFRICAN HUNTING DOGS

taken immediately the place is discovered, the mothers are likely to return and remove their offspring elsewhere the moment the coast is clear.

A ranger once poisoned eight, at the carcass of a cow waterbuck which they had just pulled down. He restrained the impulse to fire, and contented himself with merely driving them off without alarming them too much. He then poisoned the kill as quickly as possible and withdrew. The dogs, which had only withdrawn 
to a short distance, returned as soon as he was out of sight, with the result stated. Of course, it is not every one who habitually goes about carrying a bottle of strychnine in his pocket. In parts of the Cape Province where at one time wild dogs were a terrible scourge to stock, their reduction was materially assisted by laying a drag, and placing small pieces of poisoned meat at intervals along its course. This plan has, however, not proved successful in the Transvaal low country.

The usual prey of these voracious creatures consists of impala, reedbuck, bushbuck, duiker, and steenbuck (in south-east Africa), but when pressed by hunger they will not hesitate to attack larger and more formidable species. Ranger Wolhuter once saw a pack pursuing a single sable antelope, but was unable to ascertain whether they killed it or not. Waterbuck and kudu cows, and immature animals of both sexes belonging to the larger species are sometimes killed, but in the Sabi Reserve, at any rate, where small buck are plentiful, their attention is almost entirely confined to these. A troop was once seen running a Side-Striped Jackal, and we have recorded instances, one of which was quoted in a previous chapter, of hyænas having been mobbed; though whether such attacks were undertaken with the object of obtaining meat or merely as acts of revenge, consequent on the hyæna having attempted to snatch some of their food, is doubtful. A leopard certainly recognizes dangerous enemies in a pack of hunting dogs, and seeks refuge in a tree on their approach.

The tales which are current of Hunting Dogs driving away lions from a district are no doubt much exaggerated. Lions seldom hunt singly, and the reason which causes them temporarily to abandon a small area, upon which a pack of Hunting Dogs has descended, is more likely to 
be the resultant scattering of the game than any personal fear. What may, and probably does, happen is that single lions, past their prime and leading a solitary existence, become, now and then, the quarry of a pack hard pressed by hunger. On finding himself thus pursued the lion would probably do his best to escape; but, when eventually brought to bay, I think he would have little difficulty in routing his assailants, unless they were very numerous, or he very old and weak. Judging by the difficulty which more than a dozen of them found in overcoming a hyæna, it seems likely that they would fare badly in attacking a lion, even were there three or four times as many present. On the other hand, lions not infrequently kill and eat Hunting Dogs. The latter are said seldom to attack full-grown male warthogs and bushpigs, but prey on the females and immature animals.

Although Hunting Dogs are expert swimmers, they more often than not decline to cross deep water, even when hot on the heels of their quarry. This unwillingness is, no doubt, due to fear of crocodiles, and hunted antelopes seem to know it well and to take advantage of it. During the dry season, when the buck are collected near the Sabi, they invariably make for the river if pursued, and every winter there are numerous cases of impalas being chased into the compound of the station, or across the river. The pack almost always relinquishes the pursuit as soon as its quarry has plunged into deep water.

I once had a very good view of a chase from the veranda of the blockhouse. An impala ram came down the opposite bank of the river, followed, at a distance of about fifty yards, by seven or cight dogs. As soon as the latter saw the glint of the water, they increased their pace, and had drawn up very close to their intended victim when he reached the river. The impala swam 
straight across, and two or three of the leaders, leaping in, began to follow; but after swimming a few yards they evidently thought better of it, and turned back to their companions, when the whole pack moved slowly away. Exceptions, however, occur. On another occasion an impala took to the water a little below the station, and swam across a deep and strong-running channel, some thirty yards in width, to an island. The pack of Hunting Dogs which was in pursuit halted on the brink, all except one, which boldly plunged in, crossed to the island, and there killed the buck, swimming back to the mainland after he had eaten as much as he wanted. This is the only case I ever knew of the pursuit being maintained through deep water; but instances constantly occur of game being chased across shallows, and killed in the water itself.

Troops of Hunting Dogs often show great indifference to man's presence, and a reluctance to retire before him, which is often, and I am sure quite wrongly, put down to the natural ferocity and fearlessness of the animals. It is probably due to the comparative immunity which, in wilder parts of the country, they enjoy from the hunter, whose time is much too fully taken up, as a rule, in the pursuit of game, to allow him to spare much of it for the arduous business of seeking and following so migratory and unprofitable an animal as the wild dog. After having been systematically hunted and shot at for a time, there is no animal which seeks safety quicker; and the pack south of the Sabi in the Game Reserve, which has undergone considerable experience of man and his ways, latterly have invariably turned down wind on finding themselves followed, so that they may be able to detect the near approach of their enemies laboriously toiling on their tracks. 
Where they have not been much disturbed, hunting dogs will allow a man to approach within forty or fifty yards of their lair before rising, when they will spring to their feet, uttering barks of alarm, and jumping up and down the better to see the intruder. After a time they will make off at a loping canter for perhaps a hundred yards, when they will stop for another long stare. If not too closely pursued, they will retreat with such leisurely indifference that the sportsman, by taking short cuts, and hurrying his pace, can usually keep on terms with them. If they have small previous experience of the rifle, the overthrow of one or two of their number at the first encounter does not appear to alarm them unduly, and a good many may be bagged before they realize the danger. The troop will often wait for a wounded companion to rejoin them, a display of loyalty most serviceable to the hunter.

In East Africa these animals are often extremely unconcerned in demeanour, many of the huge packs which roam about having, perhaps, never had a shot directed at them. From the window of a carriage on the Uganda Railway I saw four of these animals at the side of the line, and thirty yards distant from the train, engaged in eating a Grant's Gazelle. They merely raised their heads for a casual glance and went on with their meal, so that they evidently more than shared the indifference to passing traffic displayed by the other wild animals present in that remarkable country.

Their ignorance of man's capabilities for mischief, due entirely to their inexperience of him, has been the source of many extraordinary "hunter's yarns." The agitation and surprise which the unwonted sight of a human being causes among them is frequently considered to be the prelude to an attack, and the person con- 
cerned believes, and ever afterwards states, that he has had a most narrow escape. These stories lose nothing by repetition, hence the blood-curdling tales which are sometimes related both verbally and in print.

It is, of course, quite possible that in a starving condition wild dogs might prove as dangerous to human life as wolves elsewhere. Like domestic dogs, they are prone to chase anything that runs away from them; but whatever they may, collectively, be capable of, I know no beasts of prey, which, singly, show less disposition to turn upon their enemies. I have seen a great number of wounded ones dispatched with a stick, and, though they have sometimes bitten the weapon used against them, I never knew one of them make the slightest attempt to revenge itself upon a human adversary, nor, in fact, do anything except try to escape. There is no gleam of rage in the large brown eyes, such as is always apparent in those of cats in similar straits; but rather the appealing and frightened look worn by a domestic dog when injured. Nor do they display much pugnacity, so far as my experience has gone, when tackled by courageous dogs; though one of the latter, should his heart not be quite in the right place, may hesitate to go in at his sinister-looking cousin, as, wounded and unable to escape, it faces him in grim silence. We have had instances in the Reserve, however, of Hunting Dogs having been pulled down without much difficulty when resolutely attacked, and I recollect at Sabi Bridge a large rough mongrel seizing by the throat and worrying one without meeting with any resistance. On the other hand, a party of Hunting Dogs would probably chase and kill any single domestic dog which was unfortunate enough to cross their path. 
Hunting Dogs are very hardy and tough, and will go long distances after having received very severe wounds. I have heard the theory expressed, among low country residents of experience, that, owing to their purely flesh diet, these animals display a certain want of power of recovery, and therefore that one wounded is as good as dead. It is sometimes stated also that a wounded beast is killed by the remainder of the pack. I believe both these ideas to be erroneous; at any rate they are by no means borne out by the experiences of the staff of the Game Reserves, which are, as regards the former, that where the wound is so situate that it can be licked by the animal's tongue, a very good recovery indeed is made. A female running with a pack was found to have had the off foreleg shot away about two inches below the wrist joint, apparently a month or so before. The stump was still raw at the extremity, but perfectly healthy in colour; the skin was even beginning to grow over it at the edges, and, to all appearance, in a few more weeks it would have been perfectly cured. She seemed able to get along quite well on three legs; her coat was glossy, and she was in quite as good general condition as other members of the pack killed at the same time. Wolhuter killed a very old male. One hind leg had been shot away just below the point of the hock, and the stump was completely healed, while that a foreleg had also been broken on a still earlier occasion was evident from the presence of a large knob at the seat of injury. This animal was also running with a pack. In a case where I killed one suffering from a bad suppurating wound, the latter was out of free reach of the tongue. No doubt males partially crippled fare worse than females at the hands of their companions; but if an animal is able to hobble along in the track of his troop by aid of 
eyes and nose he will find, as a rule, enough discarded victuals to maintain his strength.

I have known individuals when wounded yelp much like domestic dogs; but as a rule they maintain silence, both when first hit and when being dispatched at close quarters with sticks or spears.

The Hunting Dog. possesses three distinct calls. The best known is the peculiar and rather plaintive howl usually heard after nightfall and in the early morning : this strongly resembles the last note in the call of the common cuckoo, and is repeated from eight to a dozen times in quick succession. It is the rallying cry used to collect the individuals of a pack, and to communicate the whereabouts of each after a hunt. When suddenly disturbed or alarmed Hunting Dogs spring to their feet uttering hoarse barks, much more resembling those of baboons or bushbucks than of domestic dogs. When at a kill, and also, I believe, at other times, they give vent to a curious whining chatter, probably expressive of satisfaction. *

Hunting Dogs, when caught young, become quite tame and friendly with their masters, but never quite lose their wild instinct, and, when grown up, are not very reliable in temper. A low country resident once kept two half-grown ones, which accompanied him on his hunting trips; but he said he could never teach them to be really obedient, nor to refrain from running in and tearing at fallen game, though he found them tolerably docile in other particulars. I have found small whelps very friendly indeed, and they whine and yelp much like ordinary puppies. 


\section{CHAPTER XII}

OTTERS, THE RATEL, POLECATS

The Cape Otter. This is the largest of known oldworld otters. Its cheeks, chin, and throat are yellowish white. The fore toes have no claws, and are webbed at the bases only, while the hind feet are more fully webbed, and possess rudimentary claws on the third and fourth toes.

This otter is distributed over most of Africa south of the Equator, and is found frequenting all the streams in the north-east of the Transvaal. It appears to spend a good deal of its time on land, haunting dense bush, and lying up in holes in the neighbourhood of the main rivers, and of the shallow pools found along the course of tributary sand-spruits. Its food consists of fish, frogs, freshwater crabs and shell fish. I have not personally come across any instances of its having killed waterfowl, though it is said to do so. Seeking their prey, as they often must, in waters teeming with crocodiles, African otters have to be exceptionally wary and quick; and though, no doubt, their habits, when resting and sleeping, are considerably influenced by fear of these reptiles, under ordinary circumstances they are well able to elude their attentions. The following little incident will illustrate this. A ranger fired at and wounded an otter which he saw fishing in a deep pool of the Olifants River. Although up to that moment there had not been a sign of a crocodile, almost immediately afterwards the pool became alive with the reptiles, and the otter was quickly pulled down. While in full possession of its strength, the crocodiles evidently deemed the time spent in attempting to catch it wasted. 
When at bay the Cape Otter utters a throaty "kwa-a-a, kwa-a-a."

The Spotted Necked-Otter. This is a smaller animal than the Cape Otter. The throat is spotted with buff, and the fore and hind feet are each provided with five well-developed claws, besides being fully webbed.

This otter does not seem to be met with south of Natal. It does not occur in the eastern Transvaal, though it exists in the western part of that province. It is very common on many of the rivers of northern Rhodesia.

The Ratel or Honey-Badger. This animal, akin to, and about the size of, a true badger, is remarkable in several ways, and excites my own admiration and respect to a higher degree than any other beast which roams the African jungle. Its external characteristics are as distinctive as are its habits and disposition. While the limbs, face, and under parts are quite black, above, from forehead to base of the short tail, the colour is grey, divided from the black by a white lateral stripe. In immature animals the upper parts are rusty brown, and the dividing stripe is absent. There is no external ear. The fore claws are very long and powerful, and the skin is so extraordinarily tough and loose that it is impervious alike to the teeth of the largest dog, and the fangs of the most venomous snake.

The Ratel is found through most of the Ethiopian region, and is possibly less rare than it is generally considered to be. It lives in forest, or bush country, and at all levels, both in flat and hilly surroundings. It sometimes goes about by day, but, being a solitary creature, of comparatively small size, and seldom having business in open country, it is not often met with. It lies up in holes in the ground and among the roots of large trees. 


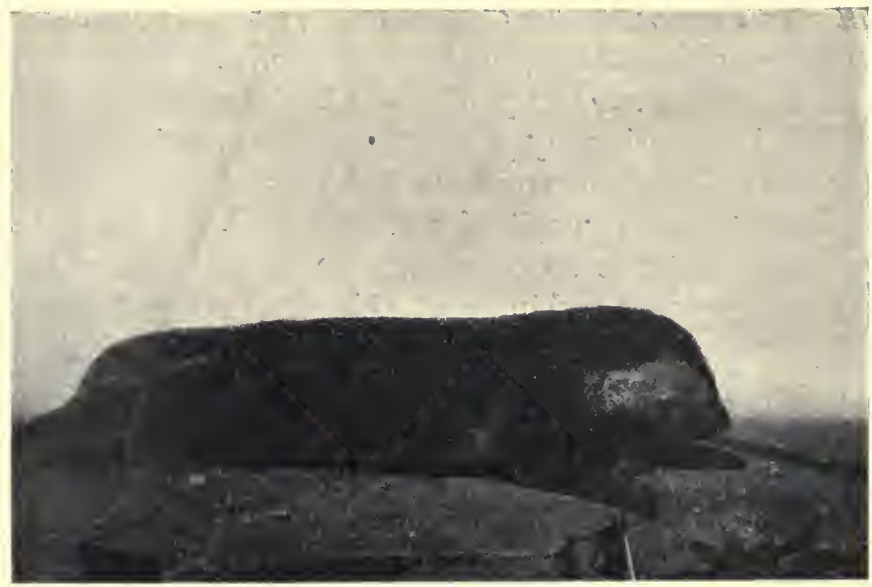

CAPE OTTER

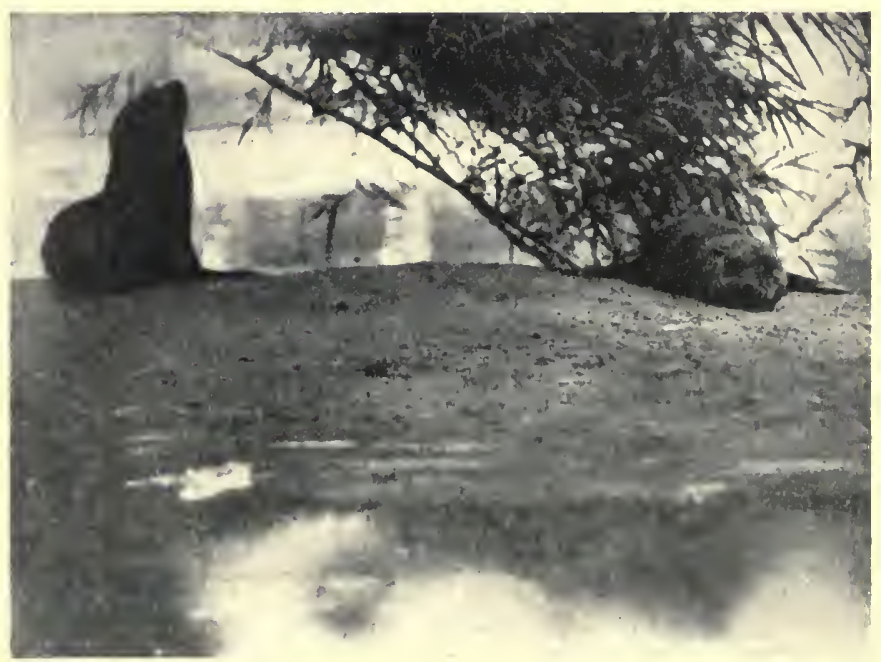

CAPE SEA LIONS AT ZOOLOGICAL GARDENS, PRETORIA 
So far as I know, it is not a climber, except possibly to the extent of scrambling up sloping trunks.

Its diet covers a fairly wide field. There is no doubt that it is occasionally a carrion eater, for it comes, now and then, to traps baited for other animals. When caught it struggles for release with the quiet but dogged persistence so characteristic of its nature, and, thanks to its loose and impenetrable skin and considerable bodily strength, usually attains freedom. It is said to be a deadly foe to snakes of all kinds. Their fangs can seldom penetrate the leathern armour which completely encases it; nor, having regard to the easy fit of this covering, is it likely that much harm would be done even if the outer skin were bitten through. Locusts, ants, beetles, and other insects also figure prominently in the animal's bill of fare, but its favourite food is certainly the honey and grubs of the wild bees, the comb containing which it tears from the nest with its powerful claws, taking no notice of the attacks of the infuriated insects.

A very interesting phenonemon in wild life is the alliance which apparently exists between the birds known as "Honey Guides" and the Ratel. You may be resting in the bush in the cool of the afternoon, or on some cloudy day, when your attention is arrested by the persistent and approaching chatter of one of these feathered spies. Presently the bird itself comes fluttering on to a branch some thirty yards distant, where it perches, flapping its wings, and displaying every sign of impatience. For a moment it is silent, and then a less familiar sound strikes the ear: a light sibilant hissing and chuckling, which at first you find yourself unable to identify: "Kru-tshee, kru-tshee-clk, clk, clk, wheetshee-tse, tse-whi-o-o" (it is almost impossible to do it 
justice on paper). The Honey-Guide understands, and having, with undulating flight, sought another tree some thirty yards further on, renews his invitation.

Keeping quite still, and looking steadily, you presently spy a little grey and black form, moving along at a steady jog-trot; the tail is carried slightly above the level of the back, and the head, except when raised to glance up at the guide, is held a little low. Every time the bird utters his monotonous refrain, which, translated into feathered language, means "Come along, come along, don't be so slow," the follower replies, "All right, my friend, don't be alarmed, I am coming." And thus the strange procession passes on out of sight to the hollow log, where the unlucky insects are industriously slaving, only ultimately to satisfy the appetites of bird and beast. When following the Honey-Guide, the natives of many tribes in Africa endeavour to imitate the curious whistling and chuckling sounds of the Ratel; though indeed the bird appears to require but little encouragement to keep it to its work.

I do not believe that there exists in the world a more absolutely courageous animal than the Ratel. He seems to fear nothing that runs, or flies, or crawls. His whole demeanour, as, sometimes at a walk, sometimes at a jogtrot, he makes his way towards some definite point, is full of the confident assurance of one who alike fears nothing and threatens nobody; and it contrasts as vividly with the scared, abrupt motions of the antelopes, as it does with the furtive movements of the beasts of prey. Perfectly inoffensive to human beings so long as not interfered with, when wounded, or driven into a corner, there is no creature alive capable of making a more gallant fight, or one which, for its size, is more difficult to dispose of. At bay, it utters a sound between 
a growl and a hiss, and makes straight for the most formidable of its enemies. I have known cases when, after a protracted struggle with a pack of dogs, the Ratel has picked himself up and jogged off, apparently little the worse from the encounter, leaving the assailants totally exhausted, and all more or less damaged.

When the Ratel has eventually been shot after a severe worrying, the skin has invariably been found entirely free from any teeth punctures, although there has existed considerable internal bruising. Major Fraser, writing of such an incident, says : "The dogs got to grips with a Honey-Badger, and had one of the biggest worries I ever saw. The badger was fairly smothered in dogs, and he punished every one of them well. They were covered with blood, and clean off their heads. They paid no attention to me calling them off, and every time I went near, the badger broke away from the dogs and came for my legs. I had to shoot him in the end; but although I had broken his shoulder, he still continued to come strajght at me. Pluck was not the word for it.'

On another occasion the same gentleman took a snapshot at some small animal which he saw moving through the bush close to the path. The next instant, quite slowly and deliberately, there emerged a Ratel, which, getting a good grip of the calf of his leg, held on like a bulldog until it was killed. A patrolling ranger once came to a spot where a lion had tackled a Ratel, and had only succeeded in killing the game little beast after a severe struggle, of which the trampled bush and grass supplied a faithful record. After his victory Master Leo apparently found small relish in the meat, for he had eaten only very little of it and then passed on to kill a steenbuck at no great distance away. It is only fair to say that all available evidence pointed to this being a very old lion. 
Here, however, is another side to the beast's character.

Ranger Duke reported under date March 3I, I908, "A wildebeest bull was found dead on the north bank of the Sabi River. On examining the carcass I found it perfectly free from wounds, except that an artery was torn, and the bull had evidently bled to death. We followed the spoor back for a considerable distance, and found signs of a prolonged struggle, the tracks of a Honey-Badger being mixed with those of the wildebeest." On several other occasions, since I have been in charge of the Transvaal Game Reserves, other rangers have reported such attacks occurring, and on each occasion the antelope was done to death. Its motive may, in such circumstances (I am not at all certain about it), be only resentment of some interference or accidental injury; except for its passing fancy for carrion, it is not a meat eater in the ordinary acceptation of the term, and in none of the cases quoted was there any indication of its having touched its adversary after death. On the other hand, it may possibly have sucked the blood, and we have occasionally found half-digested blood in the stomachs of dead Ratels.

In captivity the Honey-Badger becomes extremely tame and gentle, and is a most amusing companion. It displays an intense yearning for sugar, treacle, and, in fact, any other sweet things, which must therefore be carefully put out of its reach, with a mental note that it displays great ingenuity in prising open the doors of cupboards and presses in its search for delicacies. Where closely confined it has an amusing way of passing the time by turning somersaults. A tame one should be given plenty of water, to bathe in, in hot weather.

As an enemy of snakes the Ratel deserves well of man, 
and should therefore not be wantonly destroyed; but any one who would release this creature when caught in a trap must be prepared for all kinds of eventualities.

Polecats. There are two genera of polecats, or skunks, in South Africa, each containing but one species, The first, known as the Striped Muishond, attains an average total length of about twenty inches, eight of which are taken up by the rather bushy tail. It is a handsome little animal, jet black in colour, having four white stripes from between the ears to the root of the tail, and three white spots on the forehead and temples. It is distributed throughout central and South Africa. It is solitary in habit, and feeds on rats, mice, and such small mammals, birds, frogs, lizards, snakes, and eggs of all kinds, besides locusts and other insects. When in danger it has the power of emitting from its glands a very strong and tenacious odour. It often shams dead when attacked by a dog. Though, generally speaking, nocturnal, I have sometimes seen these little animals come out of their holes in daylight. The tail is carried more or less perpendicularly while moving, and when the owner is irritated the hairs on it are spread out, and bristle stiffly. The Striped Muishond has the same method of springing sharply from all four feet, and in any direction, so characteristic of the mungooses. When caught young it becomes very tame, and makes an interesting pet.

The Snake Muishond. This species, though much smaller, is very sinilar in its bodily markings to the last, but the whole top of the head is yellowish white. In general shape and size it is weasel-like, and apparently in food and habits somewhat resembles that animal.

With the exception of one member of the marine 


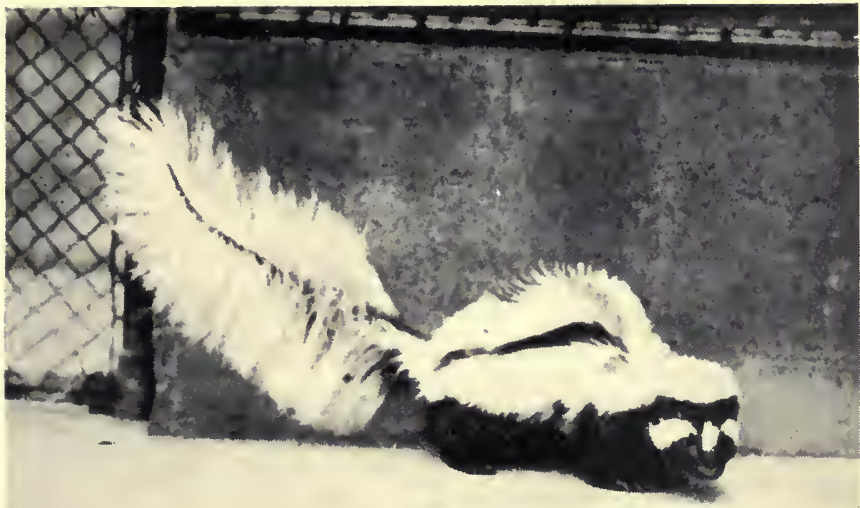

POLECAT

F. W. Bond, Photo.

(Snake Muishond)

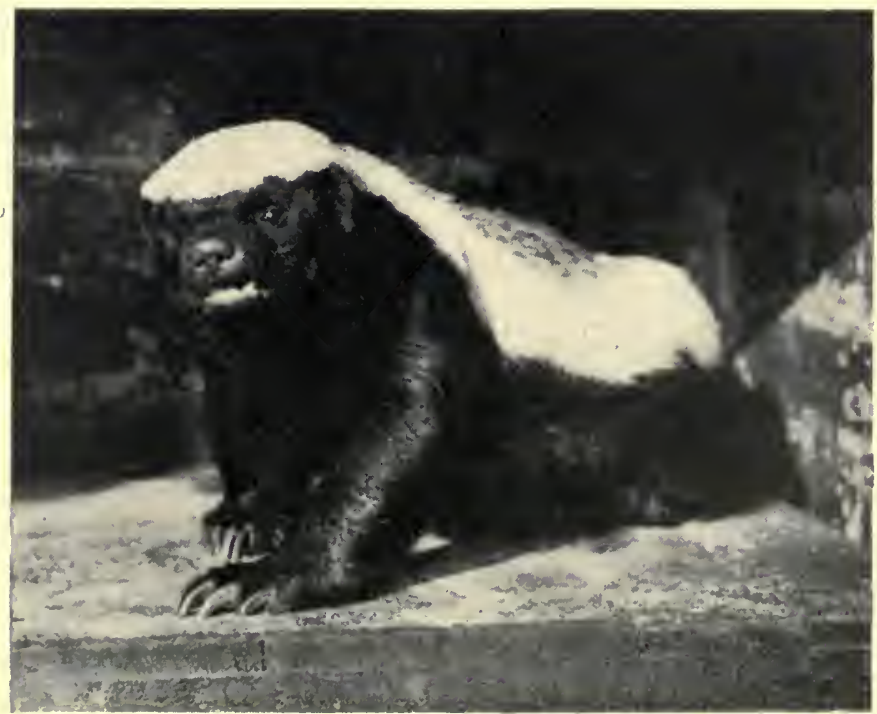

F. W: Bond, Photo.

AFRICAN RATEL, OR HONEY BADGER 
mammals, the Cape Sea-Lion, found on the islands off the coast of South Africa, and the protection of which from extermination demands constant attention, the above completes the list of families of the carnivorous order found in Africa. 


\section{PART II \\ SOME GNAWERS AND INSECT EATERS}

\section{CHAPTER XIII}

(a) HARES, SQUIRRELS, THE CANE RAT, THE PORCUPINE, JERBOAS, PANGOLINS, THE ANT-BEAR

THE continent of Africa contains a vast host of squirrels, rats, mice, shrews, bats, and other very interesting mammals, upon the correct classification of which naturalists are now busy, but from which it will be sufficient to select, for present purposes, a few of the most interesting types.

There are about seven different kinds of hares found in Africa.

The CAPE HARE is distributed over most of Africa south of the Equator, in several local races. In size it is about mid-way between a rabbit and a European hare, and in colour is speckled brown and black above, reddish white below. The tips of the ears are black; the tail is black above and white beneath. It is found both in open and in forest country. Though it does not excavate burrows for itself, it will often go to ground when pursued, a rabbit-like characteristic without which it would find existence very difficult, since it forms the prey of almost every kind of carnivorous beast and bird. By habit it is rather inclined to be a scavenger, and often comes at night to pick up refuse round native villages. I have found young ones hidden in "forms" in the long grass, 
and have never noticed more than a single one in the same spot. In the eastern Transval they appear to be born through the wet season. These hares seldom live long in captivity.

The Rock HARE is a larger animal than the above, but is smaller than the English species. Its colour above is similar to that of the Cape Hare, but it lacks the rufous tinge of that animal on the under parts, which are yellowish white. The ears are very long, and have black margins to the tips. There is a reddish patch at the back of the neck. The tail is similar to that of the last kind. This hare is found in hilly country southwards from the Zambezi.

The RED HARE has only recently acquired the dignity of a separate genus. The upper parts are speckled black and brown, and the underneath portions are rufous white. The limbs are rather shorter than those of the last genus, and the tail is rufous both above and below. The red hare is fond of elevated and hilly country, and is distributed through most of the Ethiopian region in several sub-species.

The Grey-footed SQuirrel. This is the commonest squirrel in the north-east of the Transvaal. In colour its coat is pepper and salt, with a yellowish tinge; it has a long and rather bushy tail, and its limbs are lighter in colour than the body.

It is rather a confidential little animal, spending a great deal of its time on the ground when feeding, but it always makes at once for the nearest tree when alarmed, moving at a good pace, its tail carried high. If you are sitting in the bush or under a big tree, it will not be long before one or two of these little animals comes to investigate the strange apparition at close quarters, but it is necessary to remain quite still, the first movement 
frightening it away to covert. If not alarmed, and curiosity satisfied, a pair will soon begin to play, chasing each other up and down among the branches with great agility, and often scampering backwards and forwards across the open to neighbouring trees; they can race up the bare trunks without any perceptible check of speed. These squirrels seem to be active all day, except during the hottest hours, when they lie up among the branches, or in holes in the trees. Apparently their food consists mainly of berries, fruits, ground nuts, and tubers, many of which are found on the ground, so that the animals are frequently discovered at quite a considerable distance from any large trees.

The Red-HeAded SouirRel. This animal is brighter in colour than the last, owing to the reddish yellow colour of the coat, while the insides of the limbs are bright brownish red. It is not met with habitually on the ground like the Grey-Footed Squirrel, but favours the branches of large trees, and clumps of thick bush, so that it is much less frequently seen. It carries its tail high, and is constantly jerking it up and down.

The Cane Rat. The cane rat belongs to the same division of the animal kingdom as the porcupine, and is found throughout most of Africa south of the Sahara. It attains a total length of about thirty inches, and is stoutly built, averaging about twelve pounds in weight when full grown, and sometimes scales a couple of pounds in excess of this. It is entirely destitute of fur, being covered instead with coarse bristles of a generally light brown colour, yellow at the bases, and turning to black at the tips; on the chin they are whitish. These bristles come off very easily, and in fact the nature of the skin is very remarkable; it is thick, but at the same time 
soft, and lacking in elasticity, so that great care must be exercised in sewing up specimens. The ears are rounded and very short; the tail is rat-like and measures a good deal less than the head and body; the legs are short.

The Cane Rat haunts the reed beds which border so many African rivers, lakes, and pools, lying close in its shelter by day, and by night feeding on the young shoots, as well as on the roots and leaves of water-plants. It is a pest to any gardens which may be planted near by, as it cuts right through the stalks of the maize and millet with its sharp teeth. It is a strong swimmer, and almost invariably takes to the water when pursued. Cane Rat hunting with dogs affords quite good sport, and is largely indulged in by the natives of the Transvaal low country, who are very fond of the meat. The latter is very tender and good, and no one need have the least hesitation in partaking of it, for this animal is a purely vegetable feeder, and the term "rat" is entirely a misnomer. Though rather solitary in habit, amid suitable environment, the Cane Rat exists in great numbers, and at Sabi Bridge has always formed a never-failing stand-by for the feeding of captive carnivorous animals.

The Common Porcupine. This porcupine is spread over the greater part of the Ethiopian region, and is found in almost every description of country, whether flat or hilly, open or forested. It is strictly nocturnal and solitary in habit, spending the day underground in burrows and holes, whence it comes forth at night to seek its food in the shape of roots and fruits. It is a serious foe to cultivation, having a well-developed taste for grain of all kinds, as well as for pumpkins, cultivated roots and bulbs.

It moves at a shuffling walk or trot, with much rattling 
of the loose quills of the tail. Deficient in speed, it relies for protection upon its sharp quills, which, when the animal is angry or frightened, are raised on end, thus presenting a bristling hedge to its enemies. The spines of the tail are detachable at will, and, when attacked, the porcupine, endeavouring to keep his back turned to the foe, swings this appendage in such a manner that its loosened quills are left sticking deep in the adversary's flesh. Should the eyes, nose, feet or tongue be pierced by these needle-like weapons, the results to the aggressor, whether lion, leopard, or caracal, may be very serious, and sometimes permanently crippling.

When about three days old, young porcupines begin to display on their backs a few white bristles, heralds of the future quills. The little ones remain in the hole which has witnessed their birth until their natural defences have grown and hardened, after which they accompany their mother on her nightly expeditions, until big enough to look after themselves.

The flesh when cooked resembles mutton in colour, and that of females and young animals is quite good eating; old males are very tough and gristly.

The Spring Hare. Akin to the true jerboas, this remarkable creature is found locally through Africa south of the Equator. The head and body measure about two feet, and the tail is long. It derives its name from its kangaroo-like method of progression. It is an expert burrower, goes about at night, and lives in colonies in large and complicated warrens. The flesh is good cating.

The Paxgolin and the Ant-Bear are the only African survivors of what, at an carlier epoch of the earth's history, was doubtless a very large group. Teeth are entirely absent from the Pangolin, while in the Ant-Bear 
they are present only in the cheeks, and are different in formation and character from those of any other mammals, being composed of closely packed columns of dentine, devoid of enamel.

The Pangolin, or Scaly Ant-Eater. This is an armadillo-like creature, covered, except underneath the body and on the insides of the limbs, with broad, overlapping and horny scales of a dark brown colour. The head is reptilian, the limbs are short, and the feet furnished with long and powerful claws. The tail is long and broad, being, like the body, covered with scales. When full grown, the animal averages about forty inches in length, over all, and appears to be found through tropical Africa to about the latitude of the Orange River.

It lives in both forest and open country, is solitary and quite nocturnal, and spends the day underground in burrows of its own manufacture. Its food consists of ants and termites, which it captures by breaking into their nests and licking them up with its long tongue. It has no means of defence, except to roll itself up in a ball within its armour.

The Ant-Bear. The newcomer in the African veld soon finds his attention attracted and his curiosity excited by the number of yawning tunnels and holes, which, in many districts, are to be seen everywhere dotting the ground. Sometimes they appear singly, while at others an area is literally honey-combed with them. Partially or entirely hidden in long grass, as they often are, they form a constant danger to horsemen, and riding at speed, especially in a close country, necessitates the utmost vigilance upon the part of both horse and rider. Although African-bred ponies are marvellously quick at avoiding, and even apparently guessing the presence of these pitfalls, nevertheless many very bad 
falls are sustained by hunters and others, even when thus mounted, while the use of a foreign-bred animal implies early disaster. These holes are, as a rule, the work of the animal known as the " Ant-Bear," a creature now confined entirely to Africa, though fossil remains indicate that its range was once a wider one.

The Ant-Bear is about the size of a half-grown pig, which it rather resembles in its thick skin, destitute of all fur, and covered with scanty reddish brown hairs. The tail and ears are long, the former tapering from the root, where it seems merely a prolongation of the body, to a thin tip. The muzzle is long and narrow, terminated by a small pig-like snout; the tongue can be protruded to a great length and is sticky. The limbs are stout, and are furnished, especially in front, with powerful digging claws.

The Ant-Bear exists practically wherever there are white ants, and is not in the least a rare animal, though, in consequence of being one of the most strictly nocturnal in habit of all mammals, and spending the whole day underground, it is very rarely seen. Its hearing is very acute, and sight and smell seem both well developed. When sitting up for carnivora on moonlight nights, I have once or twice seen these creatures above ground; and there is no doubt that they wander considerable distances during the hours of darkness, for their tracks are constantly seen in sand-spruits and elsewhere. At such times individuals must occasionally fall victims to the various beasts of prey which are then abroad. Once I found a male killed by a Ratel. When disturbed they at once make for the nearest hole, and in soft earth can burrow so fast, that they make more progress than several men digging hard. Their capture, therefore, is a matter of considerable difficulty. An Ant-Bear once 
fell into a covered pit which had been dug for the capturing alive of game. I have no idea how long he had been there when the natives arrived in the morning; in any case he had not made much impression on the walls of the trap, which had been hollowed out of very hard and rocky soil.

The Ant-Bear's food consists exclusively of ants and termites. Its method is to break into one or other of the big or little ant-hills which so widely decorate the African landscape, and, having sufficiently disturbed the inmates, to introduce its long and sensitive tongue along one of the numerous thoroughfares which permeate the nest. So soon as this sticky member is sufficiently covered with the alarmed termites, it is withdrawn into the mouth, to be extended once more for a fresh supply, until hunger is satisfied.

It is a perfectly inoffensive, and, if its excavating tendencies are excepted, harmless animal ; indeed such inconvenience as it causes in this way may be held to be more than counterbalanced by the heavy toll which it takes of those pests of Africa, the white ants.

An Ant-Bear killed in the Singwitsi district, was found to be suffering from a disease akin to measles, the lungs, liver, and loins being covered with spots. In spite of this some of the natives ate the flesh with relish, and suffered no apparent after ill effects. These animals are usually very fat, and the meat is considered to be quite good. In captivity they become very tame, although, during the daylight hours, they suffer from unconquerable sleepiness, and protest in a determined, if passive, manner against any attempt to disturb them. They show considerable intelligence, and, at what they deem a reasonable hour, will play amusingly with any one whom they know. In captivity they will eat porridge 


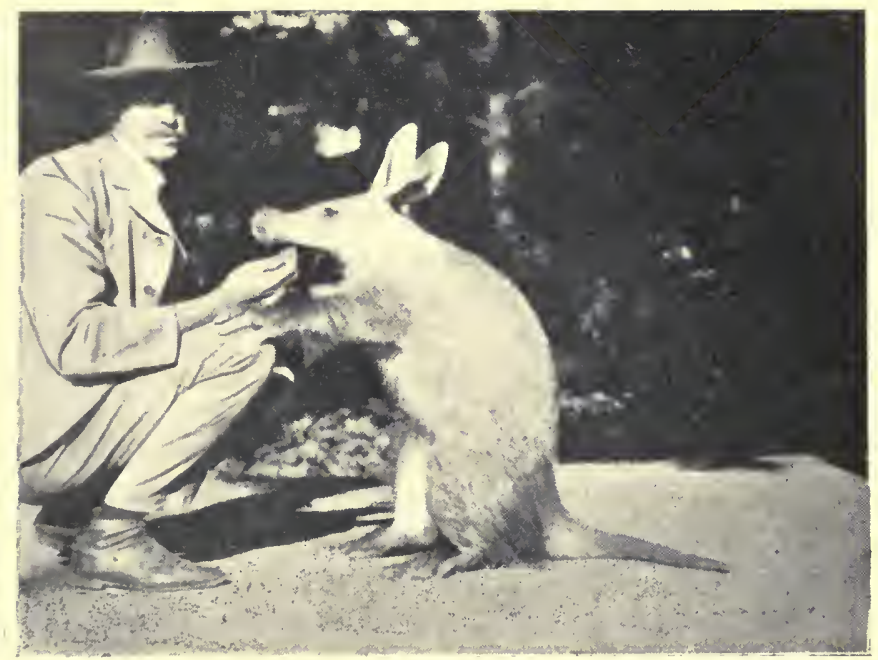

ANT-BEAR

(Transvaal Zoological Gardens)

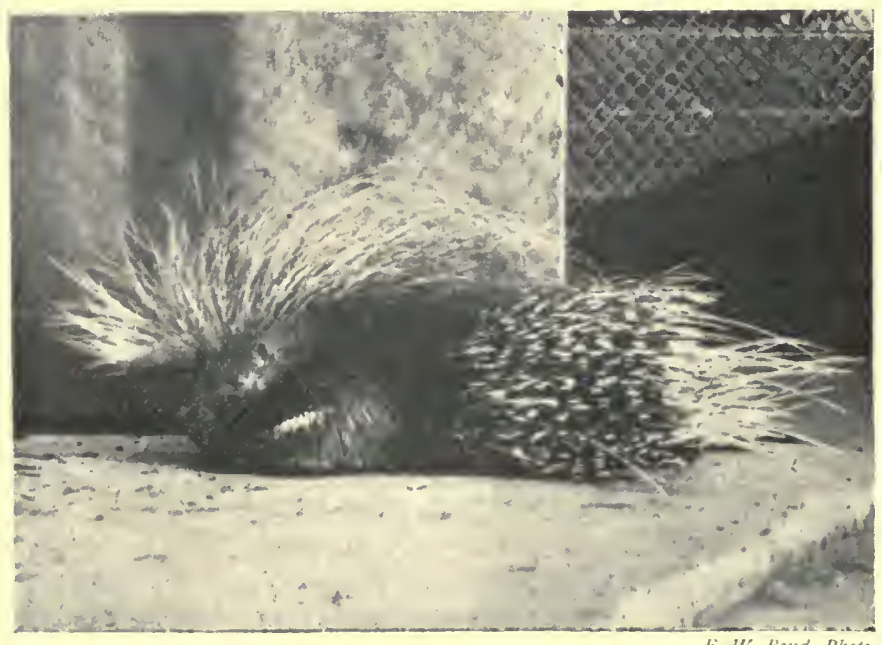


and milk, raw eggs, and raw meat chopped up into very minute fragments.

Several varieties of the animal have been described from different parts of Africa.

\section{CHAPTER XIV}

\section{APES AND MONKEYS}

Apes, monkeys, baboons and lemurs belong to the order known as Primates. All the African members of this order are arboreal in habit, and therefore are found only in more or less forested country. Their food is composed of roots, fruits, and herbs of various kinds, while a great many species are also insectivorous. Their eyesight and hearing are acute, but the faculty of scent is little, if at all, superior to that of human beings, and they do not rely upon it to warn them of approaching danger.

The apes, in their intelligence, size, and certain physical characteristics, including lack of any tail, approach more nearly to man than any other of the lower animals. Of the family, the Chimpanzees display the most striking human resemblances in this structure, and in their mental powers. These apes are found in the forest regions of equatorial west and central Africa, where they consort in small family parties:

The Gorilla is the largest of the group, the male standing sometimes over six feet in height. Its range extends only through a limited portion of the forest zone of west equatorial Africa.

Both the above species are able to walk in a more or less upright position.

The family of the monkeys and baboons, in Africa, south of the Sahara, is made up of the Guerezas, the 
Guenons, the Mangabeys, the Gelada Baboons and the Dog-Faced Baboons.

Of the Guerezas, of which about a dozen species are spread across tropical Africa, the best known is the beautiful White-Tailed Guereza which is found at high elevations in the forests of east central and east Africa. It is clothed in a mantle of long, silky white hair, which falls upon either side of its body, and contrasts with the centre of the back and the head, which, except for a white ring round the face, are glossy black. The tail is long, bushy, and pure white. In former days, the skins were favourite adornments of native warriors, and latterly have been so much sought after by Europeans that the species is now protected under the game regulations in British territory.

Another type, which has the latter third only of the tail, white and bushy, and the rest black and short haired, exists at lower elevations.

The White-Tailed Guereza is found among the tops of the tallest trees, preferably of those growing on the sides of ravines and water-courses. It is useless to seek it amongst the scrub and bush in the neighbourhood of villages, for, being of all monkeys perhaps the most timid and retiring, it keeps far away from the habitations of man. It is entirely arboreal in its habits, and is seldom, if ever, seen on the ground. To find it in its native haunts in east Africa, the steps must be directed to the heart of one of the great upland forests, where also dwell the bongo and the giant hog.

Leaving our camp at dawn, we breast a steep ascent of maybe a thousand feet, and, the open or lightly-bushed country spread like a map at our feet, find ourselves on the highest terrace of the tableland, the region of undisturbed primeval forest. 
Guided by one of the local natives, we now plunge into a sea of tangled undergrowth; great creepers catch across our chests and faces; the light shines dimly through the high overhead canopy of leaves. We cross watercourses, and plunge through half concealed morasses ; sometimes we are descending the sides of almost precipitous ravines; at others we are scrambling upwards on hands and knees, our eyes are kept constantly employed scanning the branches aloft, but for a long time our search goes unrewarded.

Presently something white and gleaming seems to fall vertically from a bough, and there is a rustle and slight crashing of branches. The flying shape is, in a moment, lost to sight; but another and another follow, and we can see the branches of the surrounding trees violently agitated. It is a troop of Colobus Monkeys; but the eye can scarcely follow their swift movements, and their black and white markings so harmonize with the background of leaves and branches that it is very difficult to distinguish them when at rest. We follow on, and, when we have once more got within thirty or forty yards, the troop, which has been carefully watching our every movement, once more dashes off through the tops of the trees. There are probably not more than a dozen at most associated in one body, but here and there we may notice a single old male, swinging easily from branch to branch, obtaining a purchase from the smallest twigs, and rustling swiftly through the leaves, as he drops out of sight on the other side of a yawning ravine, which it will take us earth-bound folk a good half-hour to cross.

The Colobus never steals from crops or gardens; he finds his sole food among the leaves and fruits of the forest trees which form his home. $\mathrm{He}$ is gentle and inoffensive in disposition; but, tame though he becomes 
in captivity, he soon pines away and dies, possibly from want of his natural food, which is much more restricted in its character than that of most other types of monkeys. Indeed, it would save much trouble and disappointment if people wishing to capture and tame wild animals of all kinds were always to find out what was the natural

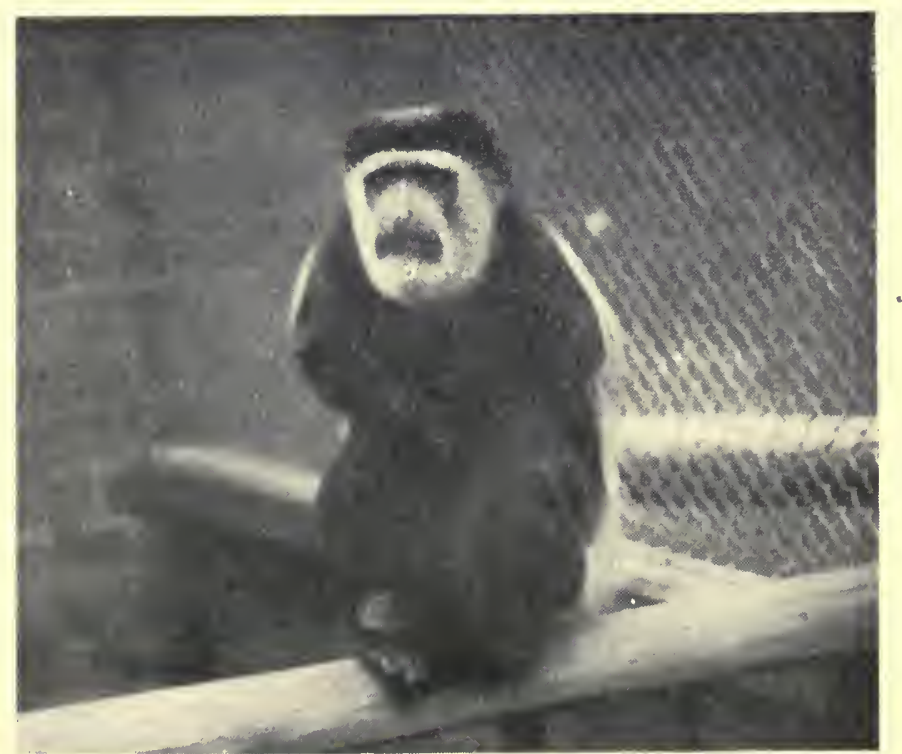

F. W. Bourd, Photo.

COLOBUS, OR GUEREZA MONKEY

food of the animal. Probably more loss of life occurs in confinement through unnatural feeding than from any other cause.

The Guenon Monkeys, which, in Africa, are by far the most numerous genus of the family, and contain over forty species, are spread practically all over the continent south of the Sahara. Their food is of a varied 
character, and, accordingly, they thrive well in captivity. They display no undue fear of man, and many species are most destructive to grain and fruit. Though trees are used for rest and refuge, they spend much of their time on the ground searching for food, and are not confined to the neighbourhood of tall forest, or even dense bush. They are noisy, and in their movements quick and restless, in such respects contrasting with the Guerezas.

The Vervet is the best known of the genus south of the Zambezi. Until recently it was divided into two species which are now believed to be identical. It is distributed throughout the bush country of the eastern Transvaal, and becomes very numerous in Portuguese territory south of Delagoa Bay, whence it spreads into Zululand, Natal, and the Cape Province. Northwards, it extends up the east side of Africa.

In colour it is grizzled grey, with a tinge of yellow, and is yellowish white underneath. The face is black, and there are rufous patches at the base of the tail.

Vervets inhabit forest and bush country, and are usually found fairly close to water. In the dry, low country of the eastern Transvaal solitary individuals and pairs, or small family parties, are most usually met with ; but a little farther south, on the Maputa River of Portuguese East Africa, I have come across troops composed of at least forty individuals. These monkeys eat fruit and seeds, and are very fond of eggs; they also seem partial to the gum which oozes from the bark of some of the acacias. They are particularly fond of millet, and when the crops are ripening may be found collected in considerable numbers in the neighbourhood of the native lands. When surprised on the ground at a distance from covert they can easily be caught by dogs. 


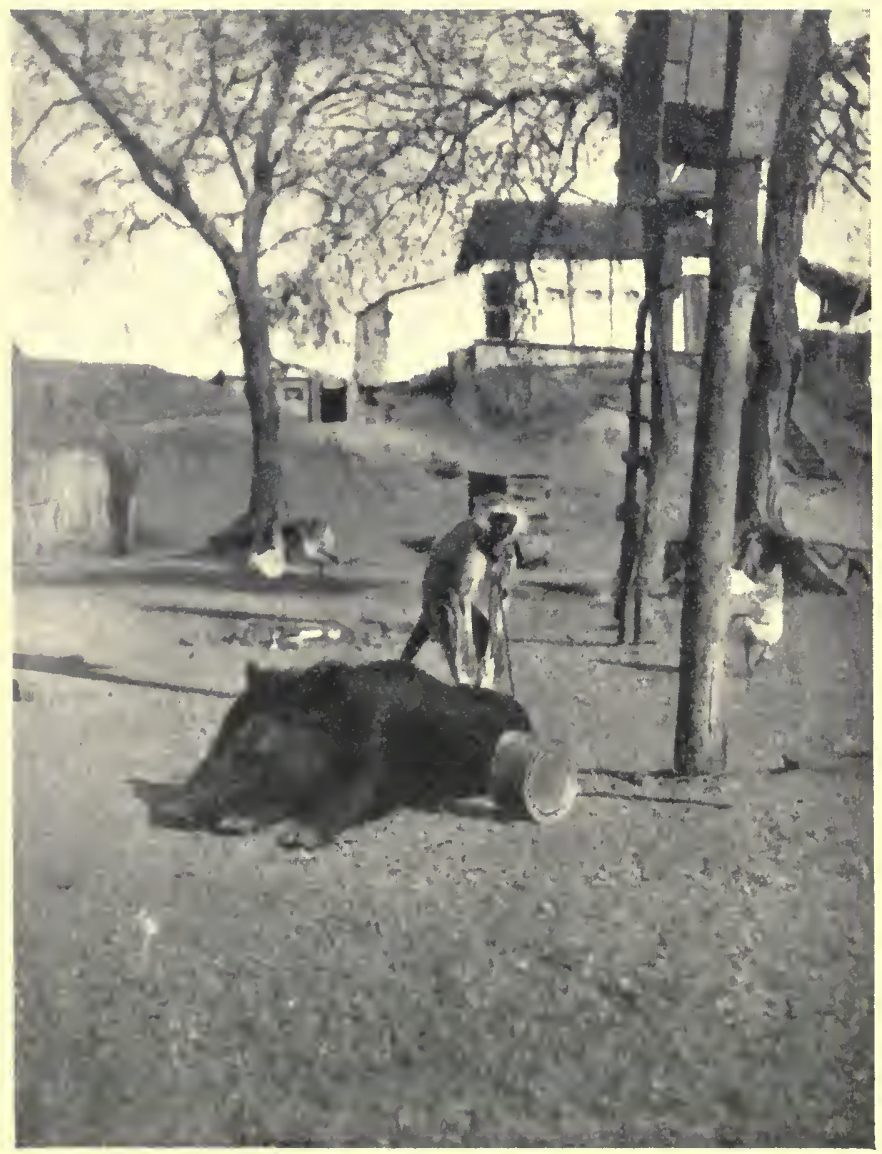

VERVET, AND PIG (see page 146) 
By night they roost in trees, usually at a fair distance from the ground.

In captivity the Vervet is at first very timid and suspicious, which may partly account for its reputation for being treacherous. I have kept a good many captive Vervets, and have found that when once their confidence has been gained they are most gentle and docile with people they know.

The intelligence of the Vervet cannot be compared with that of the baboons; still, we had a female for a long time at Sabi Bridge which developed what appeared to be almost a sense of humour. As, seated on her perch, she ate her evening meal, fragments of the feast would accidentally fall to the ground and be ravenously competed for by the fowls, which, some of them, got into the habit of regularly collecting at the spot about the same hour. After a while, the monkey, having eaten her fill, and filled her cheek pouches, began deliberately to drop scraps of porridge one at a time into the crowd. She did this quite slowly and reflectively, and seemed to derive real amusement from the contests which she created. The same monkey struck up a close friendship with a pig, and the two would spend hours together.

The Samango Monkey. This species is darker in colour than the Vervet, and there are no rufous patches behind. The fur is very silky and handsome. It extends from the eastern part of the Cape Province, through Portuguese East Africa, and the whole of Rhodesia. Its northern limit is at present undefined, but it probably extends at least as far as the Rovuma. It is found, as a rule, in thick forests, and in the dense bush which clothes the sides of ravines and watercourses.

Sykes' Monkey. This very handsome monkey is an inhabitant of east and south-east Africa, but is seldom 
found south of the Zambezi. The fur is long and thick, olive coloured on the head and shoulders, and becoming mixed black and golden-red towards the tail. I have met with it in East Africa amongst the bush on the outskirts of the main forest.

\section{CHAPTER XV \\ BABOONS AND LEMURS}

The Chacma Baboon.-This is the well-known baboon of South Africa. Its range extends from the Cape to about the latitude of the Zambezi, where its place is taken by an allied species. The Chacma varies in colour from dark brown to olive, and a perceptible greyish tinge appears in old animals.

Colour seems to be uniform in the same troop, but different troops, even within the same area, appear to vary one from the other. Thus, while in the Sabi the majority of the baboons display a distinct shade of olive green in their coats, some more and some less, I have seen troops the members of which were of a uniform dark brown colour, with little, if any, tinge of yellow or olive. Specimens shot and carefully compared leave little doubt that this is the case. Females and young animals are lighter in colour than adult males. Baboons from the Transvaal appear, generally speaking, to be a little shorter in the leg than those from the Cape Colony.

The Chacma inhabits both forest and open country, but is seldom encountered many miles away from the rocky krantzes and boulder-strewn kopjes which are so prominent features of many parts of South Africa, and to which the animals always betake themselves at night. The thickly bushed low country of the eastern 
Transvaal is dotted here and there with solitary outcrops of granite, which rise, in tumbled masses, often considerable heights above the surrounding country. The larger among these are generally each the special refuge of some particular troop, which may total anything from fifty to a hundred in number.

Like apes and monkeys, baboons are diurnal in habit, and at early dawn issue from their fastnesses in search of food. About sunset they return, each troop to its special sanctuary, to spend the night huddled up for warmth and protection among the boulders, or in fissures of the rock. During their daily rambles the most methodical and ordered combination is displayed. The troop spreads out in a sort of open order and moves across country, each individual at a sedate walk, his tail, except the latter third, which laps over, held erect. Every inch of ground is deliberately scanned, every likely stone and tuft of grass turned over or displaced in the search for scorpions, centipedes, beetles, ants, birds' or other eggs, bees' nests, ground nuts, bulbs, and all the other items of the baboon's extensive diet. Wild fruit trees are stripped clean of their burdens, and woe betide the unguarded fields of ripe mealies, millet, or ground nuts which happen to lie in the path.

When employed in a raid on cultivated lands, baboons seem perfectly aware that they are behaving improperly, and that detection means danger. Therefore, upon such occasions, it is their custom to post one or more lookouts, either in high trees or on the top of some commanding rock, in order that they may receive due notice of approaching interference. When actually disturbed, though discretion prompts swift and instant flight, their fear is seldom great enough to cause them to give up their spoil, and I have seen a troop retreat at full speed, 

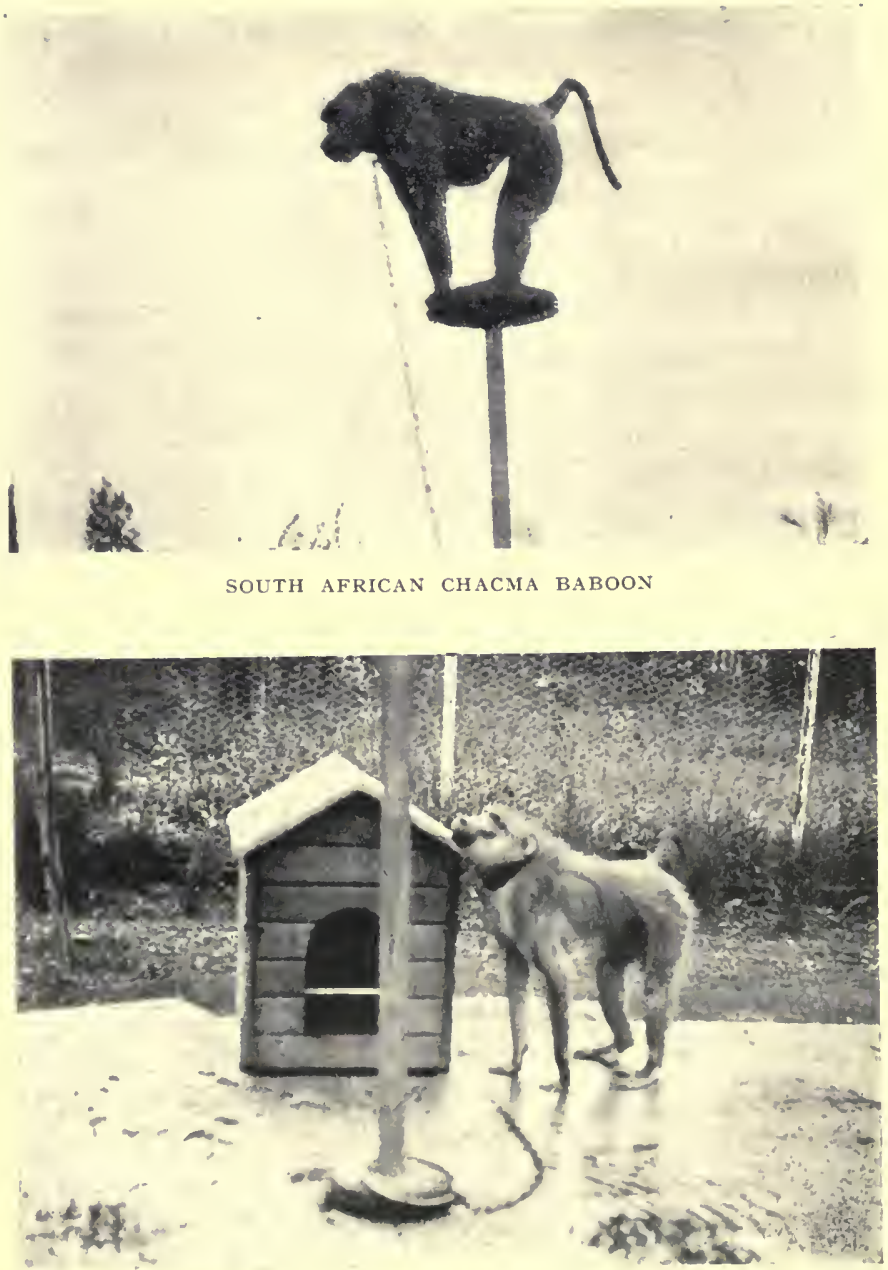

EAST AFRICAN BABOON 
each member carrying one or two mealie cobs in hand or armpit, while the cheek pouches were, no doubt, also crammed full of loot.

Although intensely destructive, the baboon nevertheless has more to his credit than is generally recognized. Locusts in the hopping stage have no more formidable enemies, and possibly they do more good in this respect than any other kind of bird or beast. Scorpions and other disagreeable insects also pay a heavy toll, and the baboon's method of dealing with the former is interesting. When the removal of a stone has disclosed the presence underneath of one of these creatures, the baboon pounces on it, and, with lightning-like rapidity, tears off the sting which adorns the end of the tail. Having thus rendered his prey harmless, he loses no time in tearing it to pieces and eating it. Although the young ones probably soon learn this trick, it is clearly a lesson learned by imitation, for an animal captured in very early infancy refused firmly to have anything to do with scorpions. It showed, moreover, the most intense fear of even a dead snake, so this feeling must either be inborn or must be implanted by the mother at a very early age.

When encountered in the forest baboons show themselves very alert and wary, making off at the first alarm ; but, perched among their rocks, in places where they have been unaccustomed to much persecution at the hands of man, they are far bolder, evidently deeming themselves secure from molestation.

The baboon is possessed of remarkable intelligence, which he displays alike in a wild state and in captivity. It is most interesting and instructive to watch, from some concealed position, the social life of a troop which fancies itself to be unobserved. Perched about at intervals among the rocks are some of the older males, 
evidently on the look-out for danger. Behind these walks or squats a confused crowd of females and of young animals, the ladies employed in various family tasks, while the boys and girls, playing and squabbling, chase each other around, to a shrill accompaniment of chattering screams. Possibly two of the youngsters, in the course of a rough and tumble, jostle against one of the senior males. Immediately the latter's attitude of dignified quiet vanishes, and he turns with a roar upon the imprudent juveniles, who retreat hastily with shrieks of pain and fear. Now and then a mother finds it necessary to chastise her offspring, or to wreak vengeance upon one or other of the unattached hobbledehoys who, she guesses, meditates imposing upon or injuring it. The air resounds with squeaks, shrill cries, and occasional bass grunts.

Suddenly from one of the guards comes a single deep, hoarse bark, and instantly there is silence : the females catch up their young offspring; the rest of the band, by one accord, scuttle out right and left, and in a moment nothing remains to indicate their former presence but one or two of the largest males, who walk quietly off, now and then stopping to glance back and to utter their resonant warning barks. If you run quickly forward, and climb to a coign of vantage, you will perhaps be in time to see the whole band scampering off, the infants clinging to their mothers' bodies, the unattached juveniles racing ahead, and the three or four fathers of families bringing up the rear at a more deliberate pace.

The cunning of the baboon has, however, apparently limits, as the occasional success of one of the methods in vogue for catching them alive proves. The mode of operation is to put a few mealies, or some other delicacy, inside an ordinary gourd, leaving an aperture only just 
large enough to admit the open hand of the animal. The first party that, comes along are not a great while before they discover the hidden treasure; some of the smaller ones are probably wrangling round it, when a big male stalks up, drives them away, and begins to examine the gourd on his own account. After turning it round and round, and inspecting it from all sides, he at last squeezes his hand into the hole, and grasps the prize. Presently, to his annoyance, he finds that, though he could put his hand in with a struggle, it is quite impossible to withdraw it, clenched, and holding the mealies. He gets angry and struggles furiously, but ineffectually, until the watchers arrive on the scene and, encumbered as he is, make him an easy prisoner. It never once seems to occur to him to open his hand and let the mealies go, but, growling and roaring with rage and fear, he grips them until the very last.

A young male, in captivity for a long time at Sabi Bridge, often showed intelligence almost human. For instance, he was accustomed to roost at night in a tree situated at about thirty paces from the native cookhouse, wherein he liked to sit, sharing the evening meal of the " boys," until just after sundown, when he would retire to his perch. Sometimes the food would be a little late, and on going out " Jack" would find himself benighted. Nothing would then induce him to cross, alone, the open space separating hut and tree, and he would sit screaming until some one lifted him up and carried him across the danger zone. Arrived at the foot of the tree, he would make all haste to the shelter of the branches, evidently deeming the ground no .place for him at that hour.

One day a very small captive of his own species was brought in, and the two were placed on the ground facing 
each other. At first "Jack" displayed the utmost self-consciousness, half turning away, and pretending to be employed displacing stones; presently he began to sidle up, and, mutual confidence being presently established, the two became quite inseparable. "Jack" was never contented unless he was carrying his small friend hugged closely in his arms, and, from having in the past constantly sought human companionship, he now rather avoided it, and resented strongly any one attempting so much as to touch his charge. It was quite a pretty idyll, and its curtailment, through " Jack" accidently hanging himself in the course of a burglary on the mealie store, was widely regretted.

Another little fellow, having developed a considerable liking for me, used to like sitting on my shoulder, and if at such a time any of the dogs came up and tried to demonstrate their affection, he would fly into a rage, jump down and chase them away, perhaps under the impression that they were trying to attack me. On all other occasions he was on the most friendly terms with them all. During my absence some one bullied him, and, finding himself uncomfortable, he ran away into the bush, and could neither be caught nor induced to return to civilization. He never attached himself to any others of his own species, but taking up his abode somewhere in the neighbourhood of a small village, he periodically raided it for food, having first assured himself that no one was at home. He then showed the results of his period of domestication in the deftness with which he would prise open the reed screens closing the huts, remove covers from dishes, and so forth. When a white man was walking or riding along the road he would sometimes appear from the bush and follow a hundred 
yards or so behind, but the moment the person faced round he would disappear.

Another baboon, confined with a Vervet Monkey, made it his business to render the existence of that unhappy creature a burden to it. He would steal its food, pull its tail, jump on it when it was not looking, and event ually so shattered its nerves that the two had to be separated. Although the two animals were, at that time, nearly of a size, the Vervet always seemed to admit the moral superiority of the baboon.

Although dogs are generally perfectly friendly with, and, in fact, often allow themselves to be bullied by tame baboons which they know, they seem to have a strong antipathy to these animals in a wild state. The most obedient dogs are with difficulty restrained from chasing a troop, often with the most disastrous results to themselves; for the rearguard of big male baboons, combining against their pursuers, and fending them off with arms and legs, while their huge sharp canines inflict terrible gashes, can hold their own against anything like equal numbers of even quite large dogs. In single combat, a big plucky dog will generally dispose of a full-grown male baboon, provided that he can secure a good hold, and that the enemy's teeth do not reach the jugular, or other vital spot. A baboon, when fighting, always bites and lets go at once, which places him occasionally at a disadvantage.

I suppose that, in the Sabi, we have lost more good dogs through these animals than by any other kind of natural enemy, except crocodiles and snakes. Years ago, on the Zambezi, I was the owner of a very large boarhound, which killed a great many "old men " baboons; but he often returned from his encounters a good deal the worse for wear. Ranger Healy had a very fine bull terrier 
which, having attacked a troop single-handed, was literally torn to pieces by a combination of three or four old males. He had evidently, following his natural instinct, held fast to the one which was found lying dead beside him, while its companions attacked him from behind.

The full-grown male Chacma being a most powerful, fierce, and plucky beast, which fights desperately in defence of its females and young, it is perhaps inevitable that its aggressive qualities should be sometimes exaggerated. Native tradition and "hunters' yarns" have, therefore, no doubt been responsible for many accounts of unprovoked ferocity towards human beings. Nevertheless there is no reason to doubt that, especially where they have not learned to dread firearms, they might be capable of combining with effect against an unarmed native who attempted to interfere with one of them. Again, during their forays on native gardens, it is quite conceivable that a number of half-hearted attempts to drive them away, on the part of women and children, followed by precipitate flight, might ultimately induce pursuit and vengeance. The freakishness of all wild animals is proverbial. Still, I think the attendant circumstances must be in some way exceptional, and in the countries in which I have lived and travelled I have never actually come across an instance of the kind. In general practice, baboons, no less than other wild things, habitually give way before man, and, not being flesh caters, they have seldom any natural induccment to make attacks upon other mammals. An exception is the habit which they have acquired, since the opening up of some parts of South Africa, of attacking the young lambs of domestic sheep, in order to obtain the milk from the stomachs. 
A troop of baboons drinking in company with a herd of impala or other antelope, or, in perfect mutual amity, strolling about, is however, a far from uncommon sight, and this would never occur did the latter fear any danger to themselves or offspring. Probably, in any attacks which may have been made on human beings,

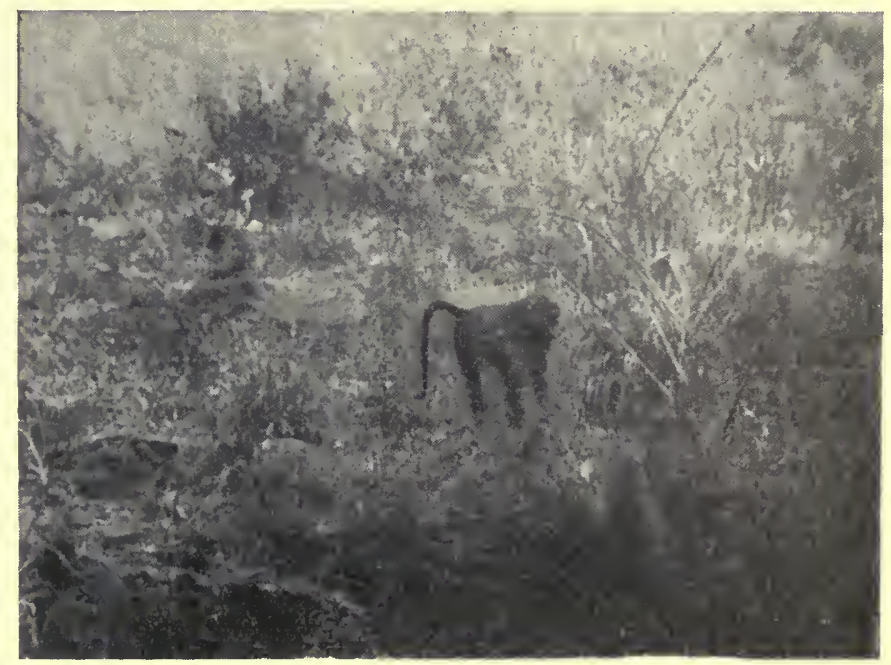

CHACMA BABOON AT A DRINKING-PLACE

(One of the very few genuine snapshots ever taken of a wild baboon at close quarters in its natural surroundings)

fear, and the anger born of fear, were the factors at work, for baboons will often combine to try and scare or drive off any creature which threatens or injures one of the community. The attitude which they adopt against a leopard is well illustrated in Sir Percy Fitzpatrick's " Jock of the Bushveld," and is no doubt typical of that usually assumed when their enemy is one which they have good reason to dread. Not long ago a leopard 
was found by the carcass of a dead baboon. It charged the ranger at sight, and was afterwards discovered to have been so desperately wounded by the baboon's teeth that it must soon have died. It had been much too sick to touch the dead baboon.

I once surprised a large troop in the bush, the members of which at once scampered off, except one half-grown animal which took refuge in a tree. The tree chosen happened to be so isolated that a leap into the branches of the next one was impracticable, and so the opportunity seemed favourable for a capture. Standing sentinel myself at the foot, with one native attendant, I dispatched the other aloft, where the little animal, perched as high up as he could go, was making the woods resound with his lamentations. Presently, to my surprise, I heard the whole troop coming back, and could see them running about, barking and chattering, inside the edge of the bush, about fifty yards away. Although apparently in a state of considerable excitement, they would not leave covert, nor attempt to cross the comparatively open intervening space.

The cause of the excitement having been at length captured, still screaming, I walked slowly towards his fellows, curious to see what they would do. When I had covered about half the distance they began to retreat, and, even after I had entered thick covert, would not let me get nearer than about thirty yards. Having followed a little further, I picked out and shot a big male, whereupon the whole troop at once decamped at top speed. During a good deal of experience of chasing and capturing baboons, on the part of my assistants and myself, this stands out as the only instance, so far as I know, of their having shown the least disposition actively to resent human interference. 
Baboons are rather soft, and easily killed. When angry or frightened young ones scream and chatter at the top of their voices; when pleased they utter a soft "m'm, m'm." They make delightful pets when still immature, but after they are grown up become in many ways a great nuisance, while the males, as they get older, become more and more morose and bad-tempered, and generally have either to be sent to some zoo, or destroyed as dangerous.

The Yellow Baboon. North of the Zambezi the place of the Chacma is taken by this closely allied type, which is widely distributed through north-eastern, eastern, and central Africa, as far as Angola on the west.

The Yellow Baboon is, as its name applies, of a much lighter colour than the Chacma, though, as with the latter species, the colour is by no means constant throughout its range. It is altogether a lankier and less heavily built animal than its cousin, with long limbs, and a relatively light body. Its habits are similar, and I saw large troops raiding native gardens near the coast in Portuguese territory near Ibo.

Several other species are described, of which the best known is the Mandrill from the forests of equatorial Africa. It is a large and powerfully built animal, and is easily to be distinguished by the bright blue and red markings of the bare portions of the face.

The Gelada Baboors. Two species of these are described from north-eastern Africa. The nostrils are on the side, instead of, as in the Common Baboon, on the front of the muzzle; the tail is long, and the head and upper parts of the body decorated with a mantle of long hair.

The Lemurs. The lemurs belong to a family of animals which has no other representative in Africa. At the 
present day the headquarters of the lemurs is the island of Madagascar.

Three genera of the family are known in Africa, of which only one, divided into about a dozen species, is native to the south of the continent.

These African lemurs are quaint little animals, with elongated fox-like faces, big, round expressionless eyes, and long bushy tails. They vary in size from the dimensions of a small monkey to not much bigger than a squirrel. They are entirely arboreal and nocturnal by habit, and spend the day curled up among the densest and thickest foliage they can find. Their food consists of fruits, insects and eggs.

The best-known south African species is the Moholi Lemur generally known as the " bush baby." It measures only some fifteen inches in all, of which the tail takes up half. It is covered with greyish brown soft fur, and has a white stripe along the nose and two black rings round the eyes; the throat is white. It is an active little animal, and its call, constantly heard at night in the bush, has given to it its pretty name. 


\section{APPENDIX}

THE following tables endeavour to show in as simple a form as possible how the animals mentioned in the preceding pages are classified scientifically.

In order to systematize the study of natural history, and to demonstrate clearly the exact relationship of different types of animals one to another, it was long since found necessary to use for them other terms than those in daily use. Colloquial names are more or less of a haphazard character, and serve in no way to indicate the places which the subjects of them occupy in the animal kingdom. Further, the same animal is known under a totally different name in each country according to the language there spoken ; indeed, it often possesses more than one name within the same country. Accordingly it was necessary to adopt for purposes of nomenclature some language common to all civilized nations. Although what is termed a " dead " tongue, Latin is yet essentially cosmopolitan, and also from its construction is by far the most suitable for purposes of classification. Therefore at the present day every known animal, down to the smallest insect, has had a Latin generic and specific name allotted to it, and takes its place amongst its own family in the proper division of its order. Under such a system, naturalists of all nations can use identical terms for any animals to which they may wish to allude, and there is no confusion.

Although the list of the carnivorous mammals which follows embraces some types not found in South Africa, I have, in dealing with the Primates, confined myself I 60 
to the sub-continent; while as regards the Rodents, I have not deemed it necessary to maze the reader with a long list of species, a large proportion of which, having no equivalent name in general colloquial use, could not possibly be recognized by the layman without the aid of a full scientific description. The divisions and families given will, however, show in what manner squirrels, rats, moles and such small creatures, are related one to another.

\section{Order CARNIVORA}

Suborder FISSEPEDIA

Division ALUROIDEA

Family FELID w

\begin{tabular}{|c|c|c|}
\hline GENUS & SPECIES & ENGLISH NAME \\
\hline Felis & leo & Lion \\
\hline ," & pardus & Leopard \\
\hline ," & serval & Serval \\
\hline , & nigripes & Black-Footed Bush Cat \\
\hline , & cafra & Kafir Cat \\
\hline & caracal & Caracal (African Lynx) \\
\hline neelurus & jubatus & Hunting Leopard (Chita) \\
\hline
\end{tabular}

Family VIVERRIDAE

\begin{tabular}{|c|c|c|}
\hline Viverra & civetta & Civet Cat \\
\hline Genetta & tigrina & Large-Spotted Genet \\
\hline 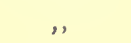 & felina & Small-Spotted Genet \\
\hline & ludia & Senegal Genet \\
\hline & letaba & Rusty-Spotted Genet \\
\hline Mungos & cafer & Large Grey Mungoose \\
\hline ," & camui & Slender Mungoose \\
\hline ,, & ratlamuchi & Ruddy Mungoose \\
\hline ,. & auratus & Golden Mungoose \\
\hline , & paludinosus typicus & Water Mungoose \\
\hline ., & , rubellus & Water Mungoose \\
\hline & pulverulentus & Small Grey Mungoose \\
\hline
\end{tabular}


GENUS

Mungos

,

,

Helogale

Rhynchogale

Crossarchus

Cynictis

$\rightarrow$

,

,

os

,

Bdeogale

Suricata

",

Proteles

Hyana

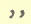

,

\section{SPECIES}

punctatissimus

grandis

albicauda

ruddi

parvula

brunnula

melleri

fasciatus typicus

senescens

pencillata typica

$$
\text { intensa }
$$

steedmanni

ogilbyi

pallidior

leptura

selousi

crassicaudata

suricata typica

namaquensis

hamilioni

lophurus
ENGLISH NAME

Pale Mungoose

Giant Mungoose

White-Tailed Mungoose

Rudd's Mungoose

Wahlberg's Mungoose

Small Brown Mungoose

Meller's Mungoose

Banded Mungoose

Banded Mungoose

Bushy-Tailed Meercat

Bushy-Tailed Meercat

Steedman's Meercat

Ogilby's Meercat

Pale Meercat

Selous' Meercat

Thick-Tailed Meercat

Slender-Tailed Meercat

Namaqua Meercat

Hamilton's Meercat

Tufted Meercat

Family PROTELIDE

cristatus

Aardwolf

Family HYæNIDÆ

striata

brunnea

crocuta
Striped Hyæna

Brown Hyæna

Spotted Hyæna

\section{Division CYNOIDEA}

Family CANIDEE

Canis

,
,

mesomelas

adustus

lupaster

anthus
Black-Backed Jackal Side-Striped Jackal Egyptian Jackal Morocco Jackal 


\section{APPENDIX}

GENUS

Canis

"v"

Otocyon

Lycaon
SPEC1ES

variegatus

mengesi

simensis

chama

megalotis

pictus
ENGLISH NAME

Variegated Jackal

Pigmy Jackal

The Cuberow

Silver Fox

Long-Eared Fox

African Hunting Dog

\section{Division ARCTOIDEA}

Family MUSTELIDA

$\begin{array}{lll}\begin{array}{l}\text { Aonyx } \\ \text { Lutra }\end{array} & \begin{array}{l}\text { capensis } \\ \text { maculicollis }\end{array} & \begin{array}{l}\text { Cape Otter } \\ \text { Spottivora }\end{array} \\ \text { ratel } & \begin{array}{l}\text { Spoted } \\ \text { The Ratel or Honey- } \\ \text { Badger }\end{array} \\ \begin{array}{l}\text { Ictonyx } \\ \text { Poecilogale }\end{array} & \begin{array}{l}\text { capensis } \\ \text { albinucha }\end{array} & \begin{array}{l}\text { Striped Muishond } \\ \text { Snake Muishond }\end{array}\end{array}$

Suborder PINNEPEDIA

Family OTARIDE

Arctocephalus pusillus

The Cape Sea-Lion

\section{Order RODENTIA \\ Suborder SIMPLICENDATA \\ I. Division SCIUROMORPHA}

I. Family SCIURIDæE (Squirrels). Four genera in South Africa.

\section{Division MYOMORPHA}

I. Family GLIRIDE (Dormice). One genus in South Africa.

2. Family MURIDE (Rats and Mice). Nineteen genera in South Africa, which contain some ninety species, and are divided into five sub-families.

3. Family BAtIYergide (Moles). Two genera in South Africa. 


\section{Division HYSTRICOMORPHAPA}

I. Family PEdetide (Spring Hares). One genus in South Africa.

2. Family octodontide (Rock Rat and Cane Rat). Two genera in South Africa. .

3. Family Hystricide (The Porcupine). One genus in South Africa.

Suborder DUPLICIDENTATA

Family LEPORID (Hares). Two genera in South Africa.

\section{Order EDENTATA}

Family MANIDE

\begin{tabular}{lcc} 
GENUS & SPECIES & \multicolumn{2}{c}{ ENGLISH NAME } \\
Manis & temmincki & The Pangolin or Scaly \\
& & Ant Eater \\
Orycteropus afer & The Ant-Bear
\end{tabular}

\section{Order PRIMATES}

Family CERCOPITHECID $\$$

Cercopithecus labiatus

stairsi mossambicus

albogularis

pygerythrus

rufoviridis

Papio

Gälago

",

,

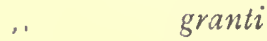

mossambicus

zuluensis
Samango Monkey

Stair's Moçambique Monkey

Sykes' Monkey

beirensis Sykes' Beira Monkey

Vervet

Vervet

Chacma Baboon

Yellow Baboon

Thick-Tailed Lemur

Garnett's Lemur

Moholi Lemur or " bush baby"

Grant's Lemur

Moçambique Lemur

Zululand Lemur

Nore.-The Guereza Monkeys are not found in South Africa. 

UNIVERSITY OF CALIFORNIA LIBRARY

Los Angeles

This book is DUE on the last date stamped below. RECD COL LIB
college JUN 1269
ubrary.

JUN 51968

ate certis in

DE? 2 . 190

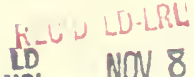

URL

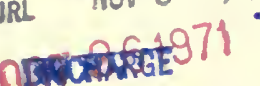

4

FEB 281978

DISCHRGE-URL

IIN $211=$

JUNN 141979

Form L9-Series 4939 
SK-251.- S848A-1917--1---
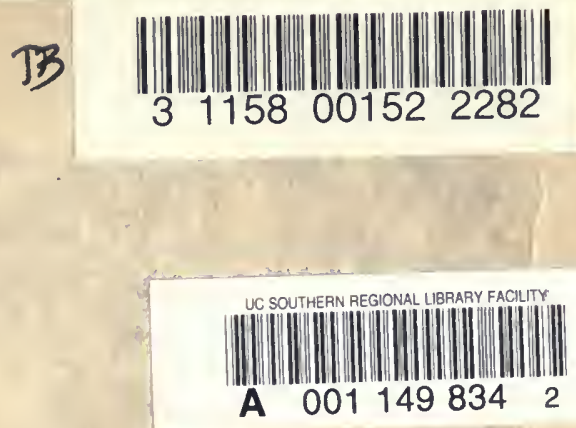


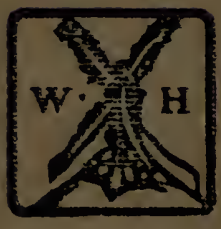

